\title{
Metaphysical Lens For Architecture
}

\author{
by \\ Ekaterina Tchouprikova
}

A thesis submitted to the Faculty of Graduate and Postdoctoral Affairs

in partial fulfillment of the requirements for the degree of

\author{
Master \\ in \\ Architecture \\ Carleton University \\ Ottawa, Ontario
}

(1) 2013

Ekaterina Tchouprikova 
Library and Archives

Canada

Published Heritage

Branch

395 Wellington Street

Ottawa ON K1A ON4

Canada
Bibliothèque et

Archives Canada

Direction du

Patrimoine de l'édition

395 , rue Wellington

Ottawa ON K1A ON4

Canada
Your file Votre référence

ISBN: $978-0-494-94575-9$

Our file Notre référence

ISBN: $978-0-494-94575-9$
NOTICE:

The author has granted a nonexclusive license allowing Library and Archives Canada to reproduce, publish, archive, preserve, conserve, communicate to the public by telecommunication or on the Internet, loan, distrbute and sell theses worldwide, for commercial or noncommercial purposes, in microform, paper, electronic and/or any other formats.

The author retains copyright ownership and moral rights in this thesis. Neither the thesis nor substantial extracts from it may be printed or otherwise reproduced without the author's permission.
AVIS:

L'auteur a accordé une licence non exclusive permettant à la Bibliothèque et Archives Canada de reproduire, publier, archiver, sauvegarder, conserver, transmettre au public par télécommunication ou par l'Internet, prêter, distribuer et vendre des thèses partout dans le monde, à des fins commerciales ou autres, sur support microforme, papier, électronique et/ou autres formats.

L'auteur conserve la propriété du droit d'auteur et des droits moraux qui protege cette thèse. $\mathrm{Ni}$ la thèse ni des extraits substantiels de celle-ci ne doivent être imprimés ou autrement reproduits sans son autorisation.
In compliance with the Canadian Privacy Act some supporting forms may have been removed from this thesis.

While these forms may be included in the document page count, their removal does not represent any loss of content from the thesis.
Conformément à la loi canadienne sur la protection de la vie privée, quelques formulaires secondaires ont été enlevés de cette thèse.

Bien que ces formulaires aient inclus dans la pagination, il n'y aura aucun contenu manquant. 


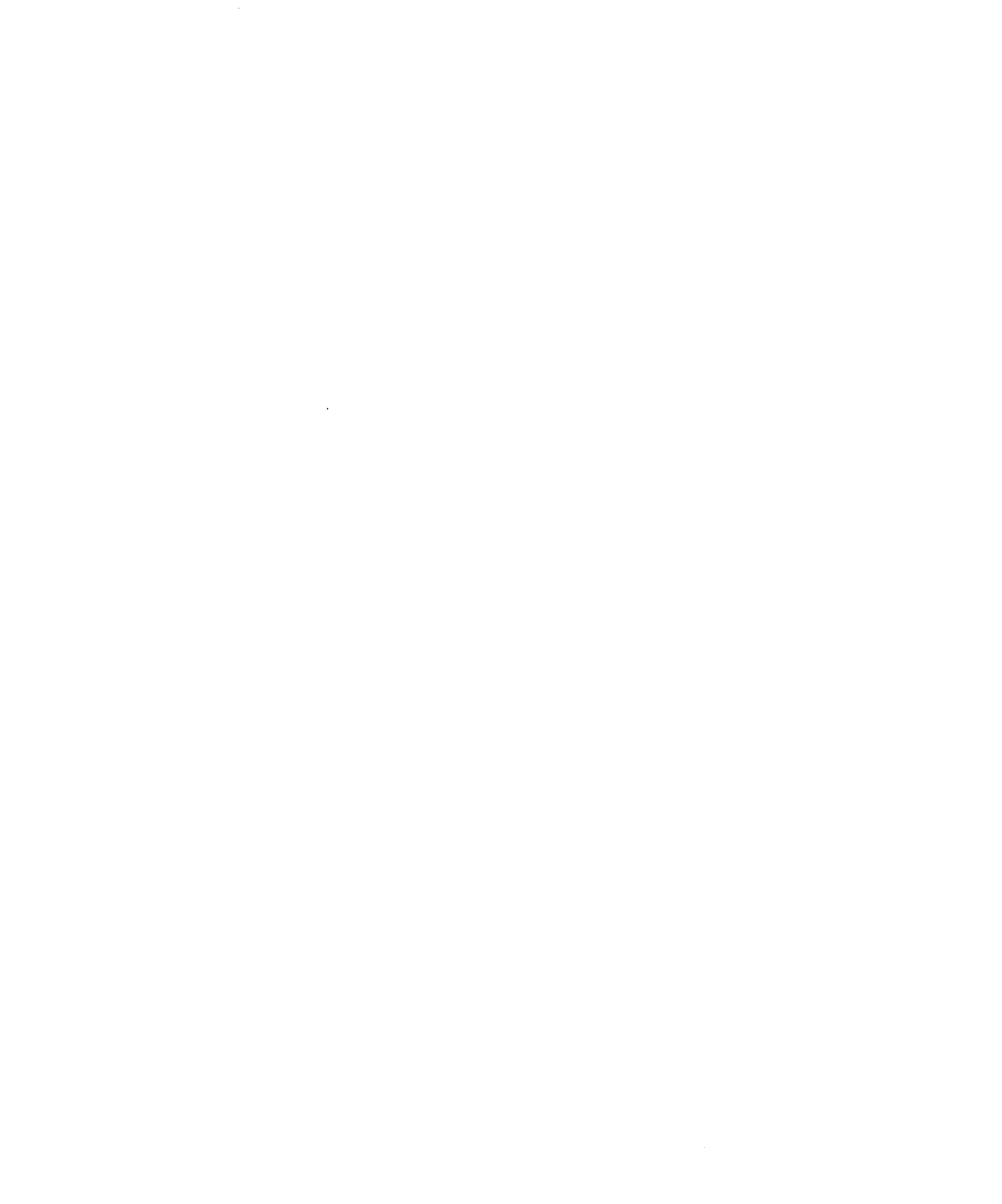




\section{Acknowledgements}

I would like to express my very great appreciation to my advisor Stephen Fai, as well as other members of the faculty Roger Connah and Greg Andonian for their help and constructive feedback.

As well, I would like to offer my special thanks to the technical staff Mark Macguigan, Rob, and Mike Getz for their valuable help with the model and printing.

I am particularty grateful for the assistance given by Fr. Mikhail Luboschinsky and Fr. Stelian Liabotis for the information on Liturgical Services of the New Martyrs and their personal support.

My special thanks go out to my friends Natalia Kukleva, Anastasiya Burchevska, Sean Coombes and Andrej Vozzhov.

Most importantly, I greatly thank my family for their support and encouragement.

Ekaterina 


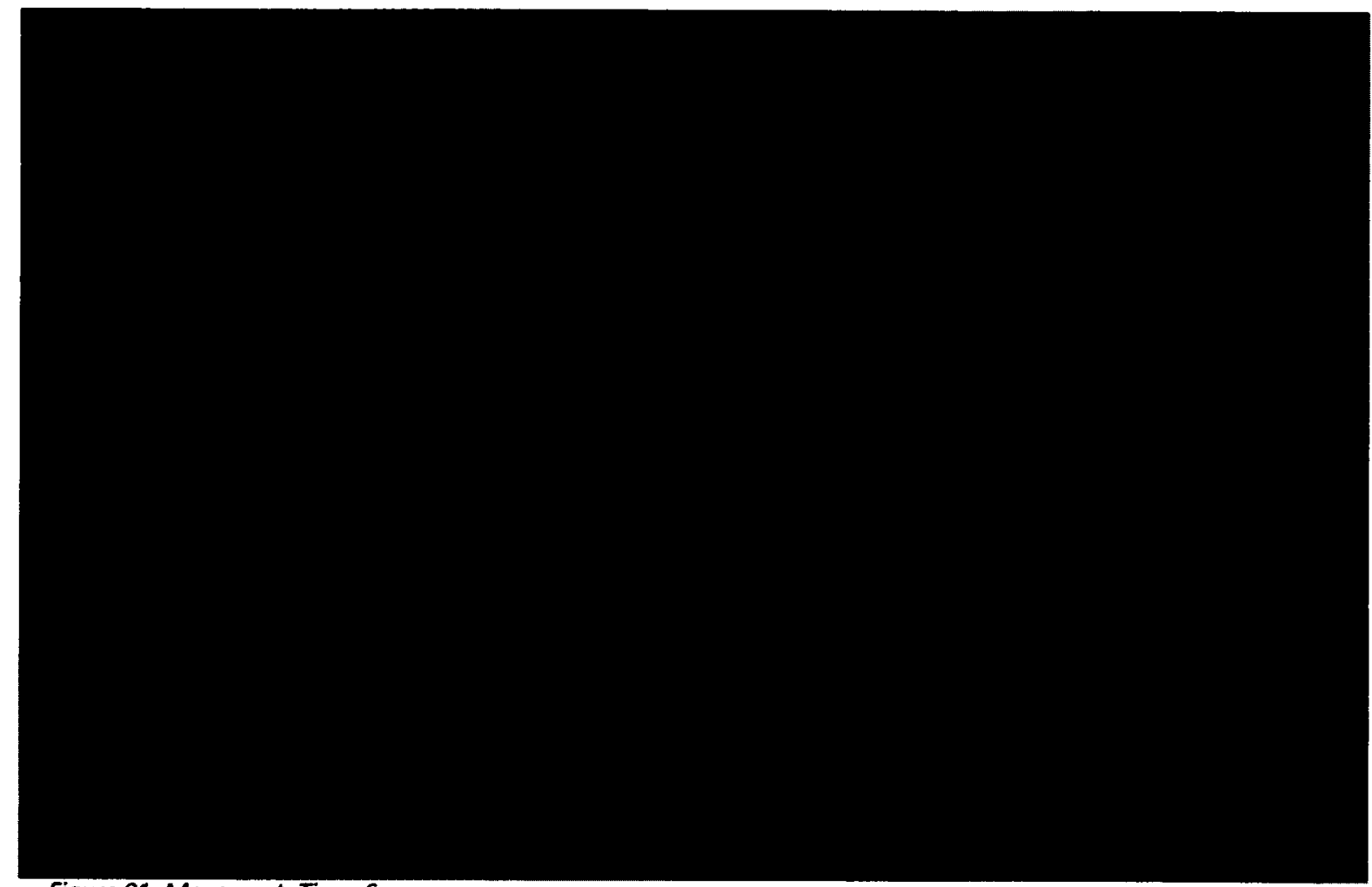

Figure 01. Movement, Time, Space. 


\section{Abstract}

New developments in the fields of technology and communications, specifically visual and virtual technology, provide tools for a diverse expression of the architectural language. It enables architects to perform a high variety of functions during the design process. These advancements, however positive, also have a negative aspect. A carefree reliance on technology often results in a positioning of the architect's role in design as secondary, and results in an architectural disembodiment. This thesis is about creating a meaningful framework for a design process within these technological conditions.

'Metaphysical', in its true Aristotelian origin, means the study of being via being. ${ }^{1} A$ 'Lens' is a meaningful process layer that allows the architect to approach the design of a building, where from a status of a lifeless object it now grows into a temporal, experiential part of reality. A 'Metaphysical Lens' for architecture is one answer to the problem of the extensive subservience to technological use in design. 
Table_Of_Contents.

$\begin{array}{ll}\text { Abstract } & \text { vi } \\ \text { Introduction } & 1 \\ \text { Major Definitions } & 5 \\ \text { 1. Technology, Expression, Meaning } & 7 \\ \text { 1.1 Visual } & 7 \\ \text { Thiftroduction } & 7 \\ \text { The Reverse Perspective } & 8 \\ \text { Self-Constructive Space } & 9 \\ \text { Visual - New Definition } & 13 \\ \text { Design Process } & 17 \\ \text { Role of the Architect } & 17 \\ \text { Relation to Metaphysical Lens } & 17 \\ & \end{array}$

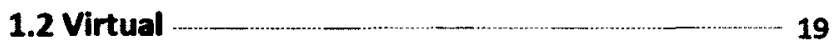

Introduction 19

Shifts 21

Systems 23

Conceptual Fields 24

Ternary Logic $\quad 25$

Virtual - New Definition $\quad 26$

Design Process $\quad 26$

Role of the Architect 26

Relation to Metaphysical Lens 27

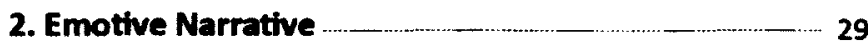

Introduction $\quad 29$

Shifts $\quad 30$

Images and Text 31

Closure 33

Emotive Narrative - New Definition 34

Design Process $\quad 34$ 
3. Metaphysical Lens

Aristotle and Peirce

Definifion of Design Process - Based on Visual, Virtual and Narrative

Role of the Architect

4. Project "Church for The Russian Martyrs And Confessors 'On Blood' that is on Lubyanka".

Sretensky Monastery - Site. Brief History

Soviet Union Period

After Soviet Union

The Orthodox Church in Russia - Symbolism 
Architecture is no longer only a spatial practice; it is a practice that causes heterogeneous temporalities to coexist, to open on the urban fabric and its ceaseless transformations, to presuppose more and more transitory functions and successive moments of life.

Manola Antonioli, 'Virtual Architecture'.

\section{Introduction}

Antonioli's excerpt highlights the importance of architecture in a temporal facet of life. Moreover, architecture's meaningful response to the needs of the human soul and spirit is what differentiates it from just a building. With the architect's increasing subservience to digital technology, however, the notion of meaning has been disoriented.

Future visual technologies work closely with the virtual realm of the psyche. In this thesis, their qualities of immediacy and interaction with the psyche are characterized as 'Shifts'. Part One of this thesis explores and defines potential strategies of technological development that affect the architectural design process using the notions of 'Visual' and 'Virtual'. Technological development within these notions, as a whole, plays a role in a certain disembodiment of architecture, or, what can also be described as a "crisis of tectonics".

Along this almost natural disembodiment process, technology's direct relationship to the psyche presents an extensive, if not limitless, field for exploration. This thesis aims to show a personal design process in consideration of such conditions, where a narrative is the best suited approach because it constructively touches upon a still-to-be

5 Gaffney, Peter, ed. The Force of the Virtual: Deleuze, Science, and Philosophy. Univ Of Minnesota Press, 2010.176

6 Crysler, Greig C., Stephen Cairns, and Hilde Heynen. The SAGE Hondbook of Architectural Theory. SAGE, 2012.519 
discovered, vastness of the soul.

Within this design process, a narrative defines a program and the meaning is brought upon by the events that shape the designer as a human. The narrative aspect of the design process will be discussed in Part Two. When the architect asserts the importance of meaning throughout design work, the technological control is enhanced by the human connection. This can result in richer architecture, as well as more meaningful technological growth.

In this way, the design process becomes an interesting and challenging way of exploring technology, which will be discussed in Part Three 'Metaphysical Lens'. It is important to assess the original definition of the widely used (and often misused) term 'Metaphysics', coined by the Greek philosopher Aristotle. In his fourth book, entitled 'Metaphysics', Aristotle defines this term as:

$$
\begin{aligned}
& \text { [A] science which investigates being } \\
& \text { as being and the attributes which be- } \\
& \text { long to this in virtue of its own nature.' }
\end{aligned}
$$

With regards to an architectural project, the word 'metaphysical' also means a motion in space. Motion adds an additional layer of meaning to the perception of space through the experience of it and allows for an architectural project to extend the engagement of the architect as 'Being'. Instead of the human essence in design process being an arbitrary faculty of the subconscious, which may not be expressed in a structural way, the solution is to meaningfully create and apply a Metaphysical Lens to an architecture project. The Lens is defined by visual, physiological and virtual aspects, as discussed in Part One, together with a narrative, that is intrinsically unique for each designer and project. In consideration of the unlimited potential of the psyche, this generally creates many possibilities for design. 
In order to realize a human role, one needs to actually

understand, even in an exploratory way, what it means to be human and to find an independent element within one's self. This is something technology cannot fully anticipate. Essentially, the architectural design needs to incorporate the human autonomy as part of its growth from virtual-tophysical realities.

Visual, Virtual, and Narrative parts of the thesis are summarized with: New Definition, Design Process, Role of the Architect, and Relation to Metaphysical Lens.

The Metaphysical Lens will be explored, in consid-

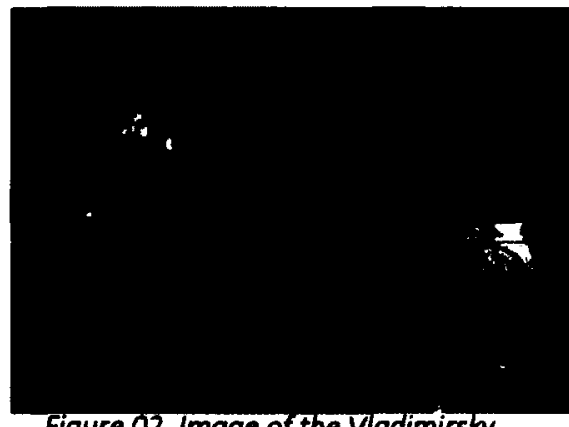

Figure 02. Image of the Vladimirsky Cathedral in Sretensky monostery. eration of a spiritual realm, in a project that deals with the extensive strengths of the human soul. Although the 'Metaphysical Lens' is to be applied for any type of architectural program, the project in exercise also contains religious and theological aspects.

The architectural project is a Russian Orthodox Church located in downtown Moscow, Russia, on the territory of a Sretensky male monastery founded in $1397 .{ }^{8}$ The project is officially titled "Church for The Russian Martyrs and Confessors 'On Blood' that is on Lubyanka", and is part of an open competition announced in October, 2012, by the monastery. The project theme signifies the unbroken power of the human will and faith in the presence of extreme physical and psychological conditions.

The aim of the project is to achieve an architectural manifestation dealing with the relationship between Visual and Virtual. In order to flourish the conditions of technological growth between them, it is done in combination with a Narrative. The independent human element is evident by the experience of the New Martyrs, who were able to maintain their humanity and faith under an extremely harsh physical and psychological pressure.

8 "Sretensky Stavropeghial Monastery." Accessed May 9, 2013. http:// www.pravoslavie.ru/english/sretmon.htm. 
The project serves as an inspiration for meaningfully reconciling the architect's human element within the advancement of technological control, while the aim of the Metaphysical Lens is to define an architectural design process. 


\section{Major_Definitions}

Introduction to major terms in relation to this thesis:

\section{Problems/Issues}

Subservience to technology - Attachment to technology to the point that the 'Being' is subdued by the technological working process.

Disembodiment of architecture - The effect of digital technology and exchange between architecture and other disciplines, which stretch the scope architectural tectonics. Loss of meaning - The misplacement of substantial conceptual framework to the technological 'Shifts'.

Role of the architect - The position of the architect with regards to design process and technology. In this thesis, the terms 'architect' and 'designer' are used interchangeably and are mainly concerning, but not limited to, architectural design.

\section{Factors}

Being - In Aristotle's philosophy, the being of any individual thing is primarily defined by what it is, i.e. by its substance. Substance constitutes the reality of individual things. ${ }^{2}$ Motion - In this thesis, motion means movement through space, expanding on Aristotle's definition of motion as actuality of a potentiality. ${ }^{3}$

Soul / Psyche - In this thesis, the soul means the 'Being' of designer. For the project, the bonding of the soul to the body and its effects are considered to the extent as needed for design. This is partially encompassing Aristotle's definition: "The soul (psyche) is the structure of the body - its function and organization." ${ }^{4}$

\footnotetext{
2 "Aristotle's Metaphysics." Accessed May 9, 2013. http://www angelfire. $\mathrm{com} / \mathrm{md} 2 /$ timewarp/firstphilosophy.htmt.

3 Sachs, Joe. "Aristotle: Motion and Its Place in Nature." Internet Encyclopedia of Philosophy (2005). Accessed May 9, 2013 http://www.iep.utm.edu/aris-mot/.

4 "Aristotle: The Body and Soul." Accessed May 9, 2013. http://www.
} 
Technological Growth / Shifts - In this thesis, it means a major impact that technology makes on society, culture, 'Being', and architecture.

\title{
Solutions in
}

Design process - Defined in Thesis Parts 1-3

Metaphysics - Defined in Thesis Introduction

Meaningful framework - Defined in Part 3 and Part 4

through the Project.

The following definitions are explained throughout thesis.

\author{
Part 1 - Visual \\ Reverse perspective \\ Inner viewpoint \\ Geometric Space \\ Meaningful skin \\ Synthetic vision \\ Tectonics, Architectural perspective \\ Physiological space \\ Part 2 - Virtual \\ Efficiency \\ Digital technology \\ Systems \\ Conceptual fields \\ Part 3 - Narrative \\ Language \\ Emotion \\ Image \\ Closure \\ Part 4-Metaphysical Lens \\ Knowledge \\ Pragmatism \\ Symbol
}


The problem of space is centrally rooted in the world-understanding of all previously created systems of thought and it predetermines the configuration of the whole system. With known restrictions and explanations one could acknowledge space as an inherent and primal subject of philosophy, in relation to which all the other philosophical subjects have to be evaluated as being derivative.

Pavel Florensky, History and Philosophy of Art. 9

\section{Technology, Expression, Meanning}

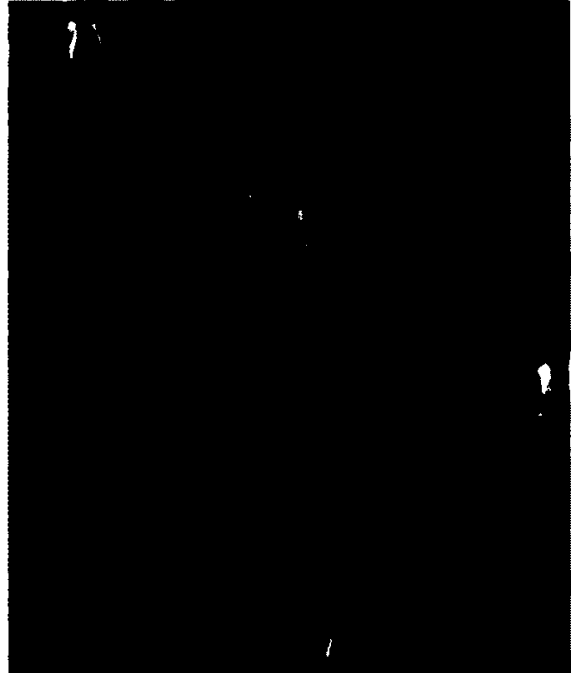

Figure 1.1. Duchamp descending a staircase. Study of body form in motion. tectural design. This is explored to eventually delineate the position of the architect with regards to these aspects of projected technological growth.

\section{Visual}

\section{Introduction}

Visual perception is critical for our understanding of and interaction with the physical reality. Spatial representation is dependent on technological shifts, which influence the position of architects when dealing with a continuously transforming visual domain.

\section{Shifts}

9 Translation by author. Florensky, Pavel. History and Philosophy of Art Accessed November 20, 2013 http://predanie.ru/lib/book/read/75786/\#TOC id 2551973. 


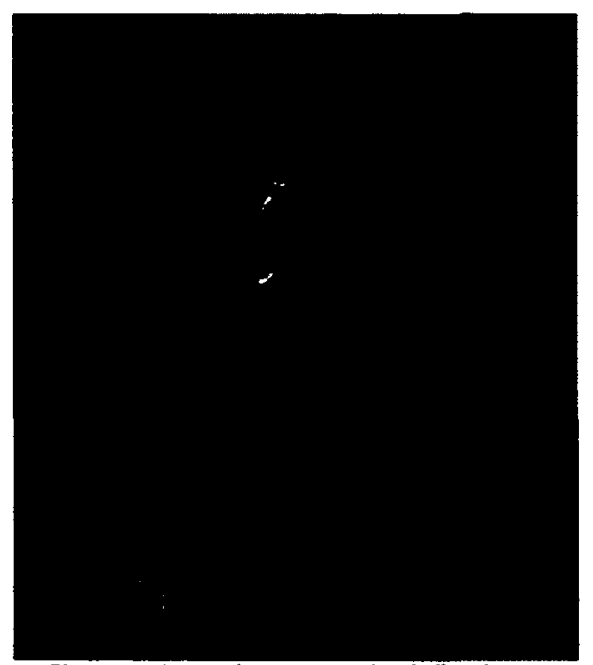

Figure 1.2. Umberto Boccioni. "Unique Forms of Continuity in Space." 1913.

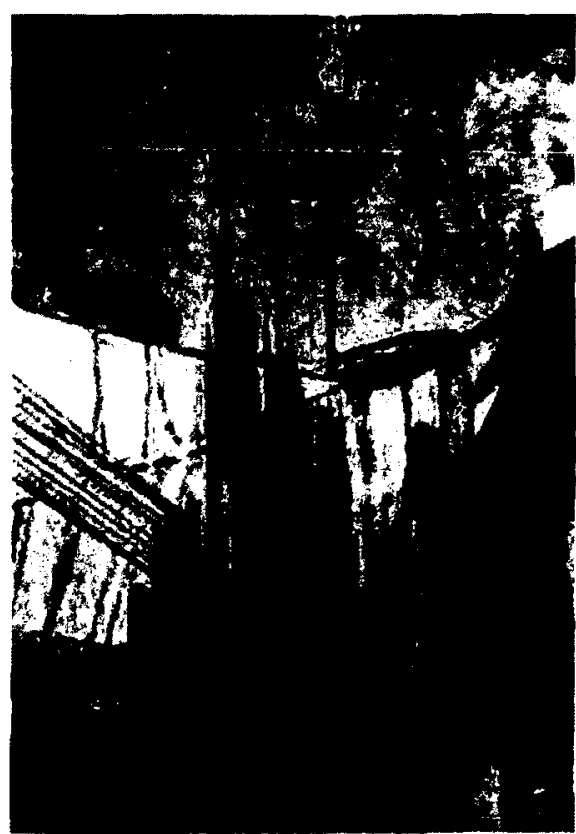

Figure 1.3. Antonio Sant'Elio. Sketch for an Electric Power Plant. 1914.
In the past, rapid technological development has been shown to influence spatial perception, since technology is directly related to our interaction with the physical environment. It is known that prior to 1876 , new technologies began to develop such as the incandescent lamp, telephone, hydraulic generators, electric trolleys and, subways, elevators, cinema, $X$-ray, and automobiles. ${ }^{10}$ This unprecedented shift led to "unparalleled technical saturation of the human perceptual apparatus," 11 whereas "innovations in transport and communications were re-defining the body and its relations to the world beyond it."12 Visually, for example, the first systematic attempt in this direction arose in the realm of aesthetics, particularly in Italian futurism, ${ }^{13}$ where there was a search to "represent episodic experiences and motion in painting and sculptures." ${ }^{14}$ For example, the sculpture by Umberto Boccioni portrays the body's motion in solidified form. In this case, motion added a multiplicity of viewpoints to the object. In relation to architecture, the most famous architect of the Futuristic movement was Antonio Sant'Elia. He applied "dramatic perspective" in buildings such as apartment blocks, transportation centers and hydroelectric plants. ${ }^{15}$

Futurism is an example of how technological growth influenced the perception of time, speed, and motion and expanded the understanding of spatial perception by introducing stronger visual dynamics and a multiplicity of viewpoints. It revealed the intrinsic connection between human spatial perception and technology.

\footnotetext{
$10 \quad$ Kwinter, Sanford. Architectures of Time: Toward a Theory of the Event in Modernist Culture. MIT Press, 2002.54

11 lbid.,54.

12 ibid. 54

13 Ibid.,54.

14 Moffett, Marian, Michael W. Fazio, and Lawrence Wodehouse. A World History of Architecture. Laurence King Publishing, 2003. 488. 15 Ibid. 488
} 


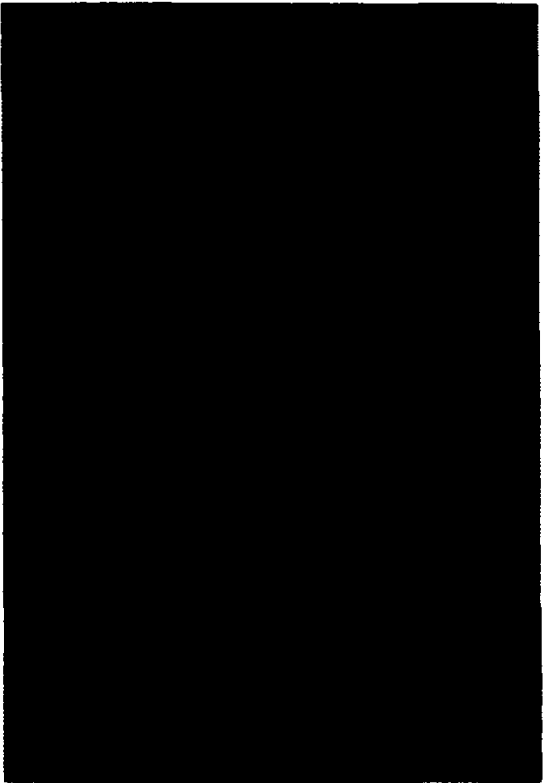

Figure 1.4. An example of reverse perspective in the icon portraying St. Mathew.
The Reverse Perspective

Around the same time period as this rapid technological growth, explorative writings by Pavel Florensky came forth. His ideas on the "reverse perspective" have offered additional meanings to human spatial perception, challenging the long-standing singular view of space exemplified in the linear perspective. Florensky's search coincided with the general tendencies of multi-perspectivity as in Italian futurism, as well as, Russian constructivism. Conceptually, these tendencies, centered on a certain type of world-understanding, which became known as nihilism. According to Sanford Kwinter, "A new order was emerging whose configuration could be expressed either in terms of a dynamics of force and a relativism or in the privative terms of nihilism and dissolution." ${ }^{16}$ Nihilism, in its denial of meaning and as "a viewpoint that traditional values and beliefs are unfounded and that existence is senseless and useless"17 was different in comparison with the belief-founded explorative writings of Florensky, who was a priest and a multidisciplined scientist. The actual term "Reverse perspective" was originally coined by Oskar Wulff at the beginning of the 20 th century ${ }^{18}$ and there are several theories attempting its explanation. Florensky's thesis with regards to the use of this type of non-linear perspective relates to the understanding of the world: "[E]mancipation from perspective or the original non-conformity to its power... is characteristic of subjectivism and illusionism - for the sake of religious objectivity and above-personal metaphysics."19 In the spatial organization of Orthodox Christian icons, the viewer

\begin{tabular}{l}
\hline $16 \quad$ bid.,54. \\
$17 \quad$ "Nihilism - Definition and More from the Free Merriam Webster \\
Dictionary." Accessed April 7, 2013. http://www. merriam-webster. \\
com/dictionary/nihilism. \\
$18 \quad$ Antonova. Clemena. "On the Problem of 'Reverse Perspective': \\
Definitions East and West." Leonardo 43, no. 5 (2010): $464-469$. \\
$19 \quad$ Translation by author. 'Florensky P.A. The Reverse Perspective.' \\
Accessed December 07. 2013. http://philologos.narod.ru/forensky/fl_persp.htm.
\end{tabular}



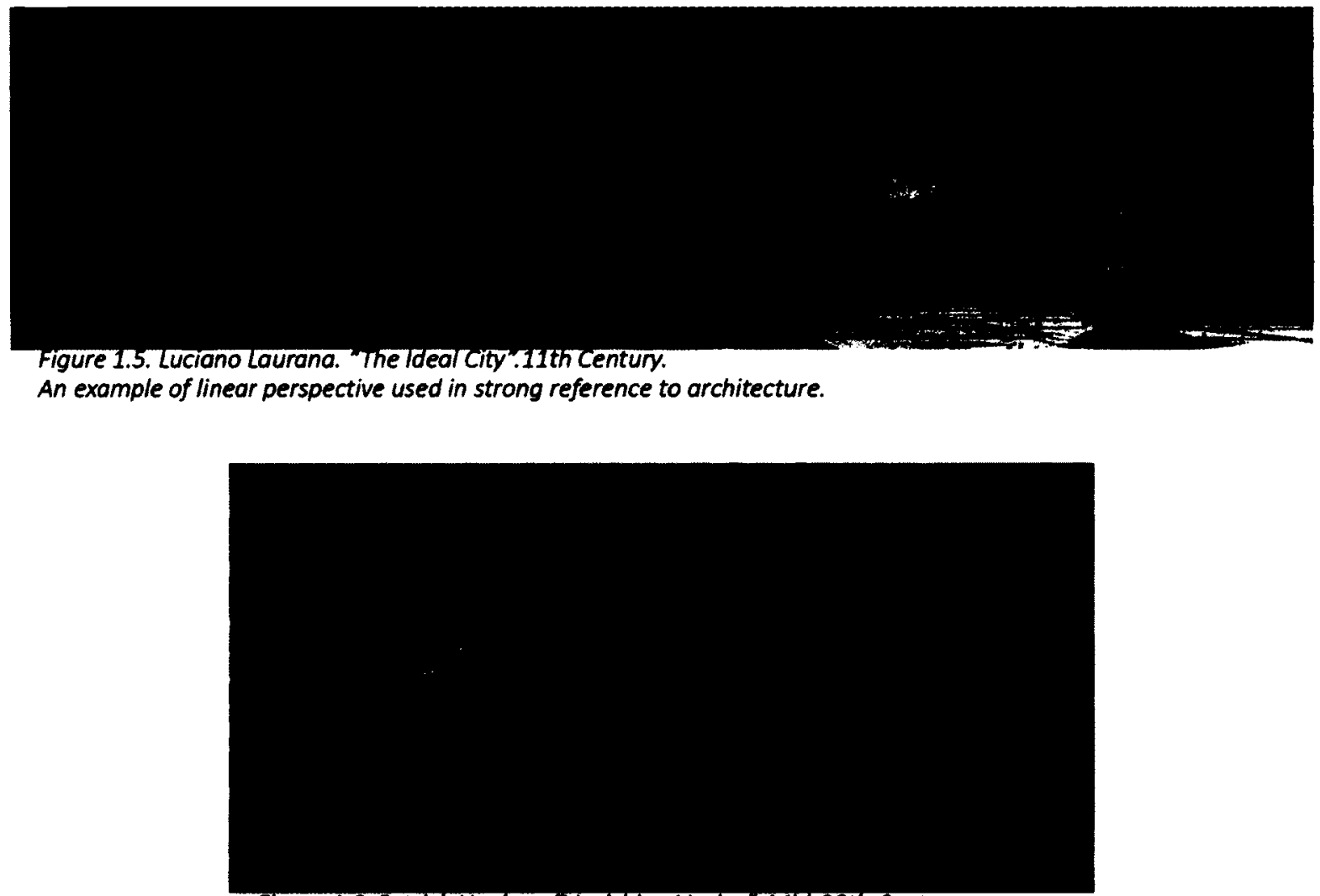

Figure 1.6. Patrick Hughes. "Vanishing Venice". Mid-20th Century.

A three-dimensional painting that 'moves' with the viewer, showing a reverse perspective effect. 


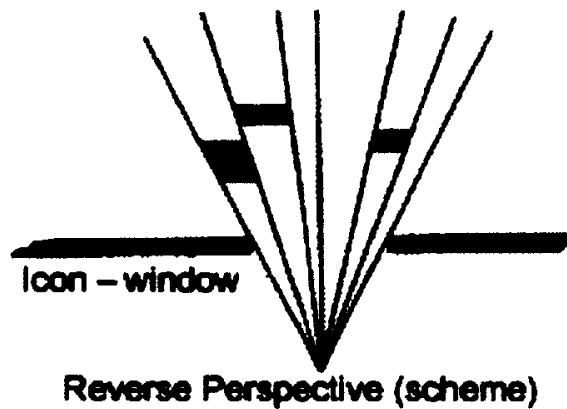

Figure 1.7. A diagram showing the relationship between the icon 'screen' and the location of viewpoint.

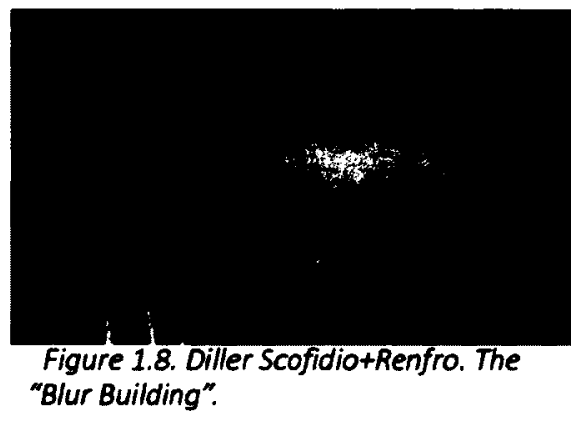

"Blur Building". contains a vanishing point from the extended icon space. $A$ principle, called 'Supplementary planes' - as described by Florensky, consists of "parts and surfaces [of the same object] which cannot be seen simultaneously" and essentially are part of so-called "synthetic vision", showing "aspects [of an object] that cannot be seen from a fixed position at one moment of time." ${ }^{20}$ His concept of spatial vision is further expanded into six points in the essay "Reverse Perspective". They summarize a certain understanding specifically in relation to visual art and indicate the importance of multiperspectivity versus linear perspective, and motion, as essential components of a creative process. ${ }^{21}$ According to the research of Antona Clemenova, another view called the "optical view thesis" was attempting to prove that reverse perspective is somehow true to the way human vision actually functions. ${ }^{22}$ Studies that try to understand the reverse perspective space suggest that reverse perspective is a "visual analogue of non-Eucledian geometry", where "space in the icon is interpreted as curved." ${ }^{23}$ These explorations are important in an endeavour to meaningfully connect cognitive aspects of perception to its actual representation on a flat plane.

Florensky writes on fine arts. Architecture is different in its vast encompassment of sensorial and visual stimuli, as there are specific colors, materials and textures used in its eventual manifestation in physical world. The word 'Tectonic,' from 'Tek' -"to make," ${ }^{24}$ generally means, "relating to building or construction." ${ }^{25}$ The Blur building by architectural firm, Diller Scofidio + Renfro is an example of

\begin{tabular}{ll}
\hline 20 & Ibid. \\
21 & Ibid. \\
22 & Ibid. \\
23 & Ibid. \\
24 & "Online Etymology Dictionary." Accessed April 7. 2013. http://www. \\
etymonline.com/index.php?term=tectonic. \\
$25 \quad$ "Definition of Tectonic in Oxford Dictionaries (British \& World English)." \\
Accessed May 9. 2013. http://oxforddictionaries.com/definition/ \\
english/tectonic.
\end{tabular}


tectonics creatively used to highly engage with the physical

feel of a building. In relation to physicality, architecture is more 'grounded' in the sense that it provides physical shelter and means of life against natural forces. The importance of Florensky's research lies in the break-down of a longstanding status of linear perspective as an ideal schema of representation. How does that relate to the essential physicality of architecture, its tectonics? In the book called "The Origin of Perspective", by Hubert Damisch, there is a reference to Sebastiano Serlio, an 16th century Italian Mannerist architect, ${ }^{26}$ who says that there is a "difference between two kinds of perspective: one (that of painters) that made its appeal to the imagination, and another (that of architects) that, working with real depth and volume, of necessity conformed to rules different from those applying in the first kind." 27 He defines this difference in the notion of "architectural perspective," 28 that reflects the intrinsic essence of physicality in architecture.

The embodiment of architecture through tectonics connects with our bodies through physicality while a human visual connection to the built environment enhances this relationship. Technological growth affected visual perception by bringing stronger dynamics and multiplicity of viewpoints. As well, technological growth also played a role in the disembodiment of architecture. This term will be discussed more deeply in relation to virtual reality, but at this point of the essay, however, the importance here is in understanding the grounded-ness of the visual connection at the same time as the natural non-linearity of vision.

Florensky's notion of 'Synthetic vision' and having a viewpoint inside a person is important because it could be

26 "Sebastiano Serlio (Italian Architect) - Britannica Online Encyclopedia." Accessed April 6, 2013. http://www.britannica.com/EBchecked/topic/535700/ Sebastiano-Serlio

27 Damisch, Hubert. The Origin of Perspective. Iranslated by John Goodman. New edition. The MIT Press, 1995. 270.

$28 \quad$ Ibid.,271. 
a possible solution for architectural disembodiment. This

'Inner viewpoint' could provide a facet of meaning for design as it is connected to body and 'Being'. The conceptual structure for this relationship is further explored in the next section.

\section{Self-construction of space}

"IT]he actual space - is not simply an even unstructured place, not a simple graph, but self-peculiar reality, organized all the way through, nowhere indifferent, having its own order and structure <...>" 29

Florensky's principal idea lies in the meaningful multiplicity within the physical reality we perceive. Since it is grounded in a specific physical context, it contains an essential uniqueness that is less prevalent in a more abstract, schematic graph. Especially as part of the design process, this is related to two specific types of space. Expanding on the differences between spatial realities, Florensky defines "[A]bstract or geometric space, physical and physiological space, which in turn can be subdivided into the space of vision, the space of touch, the space of hearing, the space of smell, the space of taste, the space of a sense generally organic, etc., each with their own more subtle subdivisions." ${ }^{30}$ The physical aspect of architecture reinforces the importance of physiological space and its visual aspects. This term is important for further discussion, and defines physiological space in connection to 'Being' and metaphysics. The key element is connection between physiological space and a personal understanding of reality, the 'Inner viewpoint'. Understanding our ability to selfconstruct space from the 'Inner viewpoint' is important in

29 Author's translation. N.K. Gavryushina. 'Philosophy of Russian Religious Art'. Moscow, Progress, 1993.259.

30 Author's translation. Florensky, Pavel. Beyond Vision: Essays on the Perception on of Art. Reaktion Books, 2006. 268. 
relation to the rapid growth of digital technology, because its 3D (three-dimensional) representation system generally contains a solid, predefined spatial schema.

A renewed embodiment of architecture within rapid technological growth can be conveyed from a distinctive world-understanding. The physiological space as part of each designer's unique mental construct needs to become an essential part of the design process. As will be discussed further, its strong visual content is affecting virtual reality.

A similar delineation of spatial reality in relation to Florensky's assertions is found in the essay by Antoine Picon "Architecture, Science, Technology and the Virtual Realm" which discusses the types of space in modern architecture emerging after World War II: "Modern architecture tried to find a balance between the geometric space and space of sensorial perception. The first was too geometric, the second, too concrete." ${ }^{31}$ The significance of geometric space, exemplified in the form of linear perspective, has grown almost continuously from the Renaissance on, ${ }^{32}$ when the creation of linear perspective enabled people to systematically visualize geometric space. Most of the current 3D visualization software uses linear perspective in order to adequately portray the most realistic 3D space possible.

There is a tension between the two types of space. Any sensorial aspects of design, when working with a 3D model, are locked into a Cartesian system of representation and may have their physiological effects subdued. It creates a problem for visualizing an object's quality throughout the design, despite the flexible nature of the digital visualization technology when it comes to scaling and animation. One of the ways to solve this conflict, according to Picon, is to use texture as a binding agent "to abolish the differences 31 Ponte, Alessandra, and Antoine Picon. Architecture and the Sciences: Exchanging Metaphors. Princeton Architectural Press, 2003. 298.

32 lbid., 296. 


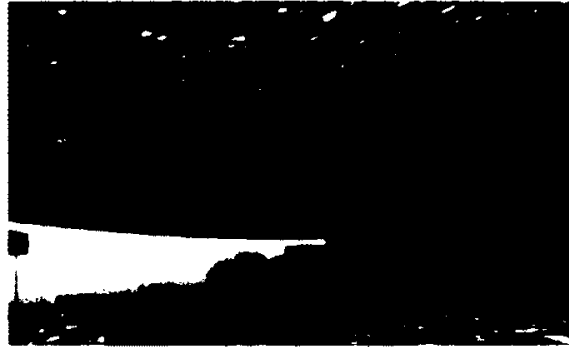

Figure 1.8 A. Jean Nouvel - Louvre Museum, Abi Dhabi, United Arab Emirates. (Expected 2015). between the abstract and the concrete.." ${ }^{33}$ Some architects, such as Jean Nouvel, used texture and light as primary guides for design, while abandoning linear perspective. ${ }^{34}$ With this approach, in a final architectural manifestation, the space becomes almost flat while surfaces and sensorial space prevail over the geometric space. Favouring this visual tactility of the physiological space over object-based approach to design is also investigated in a book by Alicia Imperiale in her description of facade systems 'New Flatness: Surface Tension in Digital Architecture':

Facades get conceived as image sensitive film, as skins with extraordinary capacities to communicate that might bring architecture into direct competition with the cinema or television. ${ }^{3.5}$

The trend of visual stimulation, in this case through the 'Skin' of the building, is taking precedence over architecture as a geometric object. The 'Skin' becomes an essential part of the design process framework.

Visually intensified perception through the elevated engagement with 'Being,' can re-engage the body to architecture on a non-static level. Imperiale notes, that

Architectural forms designed within the space of the computer are analogous to bodies moving in time. This design framework is a dramatic advance for architecture, and to appreciate this, we need only consider the existing struggle to represent space and time in the space of a flat sheet of paper, and how that surface relates to the access we gain in the digital realm through the space of the computer screen. ${ }^{36}$

Moreover, the struggle is not only to represent
Figure 1.9. An interactive screen by Sawapan. Body movement creates a constantly changing interactive mesh.

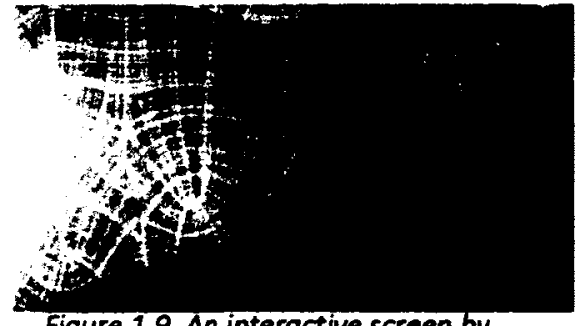

\section{.

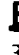


of the ways to define the 'Motion' in this case is to see the represented architecture on the screen not as an object but a symbol transferring its meaning to the designer. Symbol, in this way, brings the notion of 'Skin' to a higher, more complex level where it can be defined as a 'Meaningful Skin'. Symbol, in its designated field of semiotics means:
A word, phrase, image, or the like having a complex of associated meanings and perceived as having inherent value separable from that which is symbolized, as being part of that which is symbolized, and as performing its normal func- tion of standing for or representing that which is symbolized: usually conceived as deriving its meaning chiefly from the structure in which it ap- pears, and generally distinguished from a sign. ${ }^{37}$

Interestingly, Florensky notes that the representation - regardless of its construction model - only signifies, or hints, at the understanding of the object through the creative effort of the artist together with the intellectual mind, or

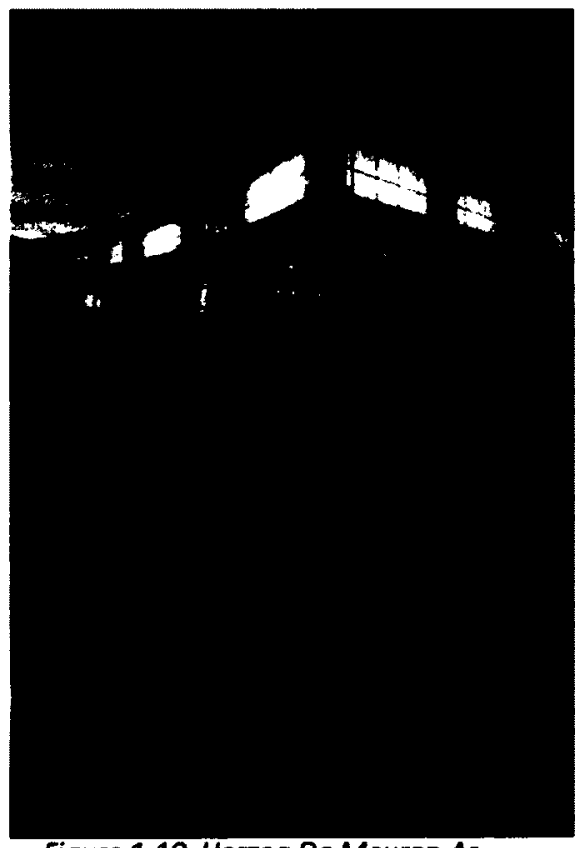

Figure 1.10. Herzog De Meuron Architects. Trinity Laban Conservatoire of Music \& Dance.
"Nous," or a Russian term, "Razum." ${ }^{38}$ He states:

[T]he latter [representation - by auth.]...is even incapable of giving a geometric likeness of the skin of things: it is essentially a symbol of $a$ symbol, since the skin itself is only a symbol of a thing. From the painting, the viewer goes to skin of a thing, and from the skin - to the thing. ${ }^{39}$

With the advancement of digital technology, the physiological space enters the space of the flat screen. Its sensorial aspects are reflected in the building's 'Meaningful Skin'. An example of visual impact reflected in architectonics is the Laban Centre by Herzog de Meuron architects. The building relates to the human body through color and texture, as nature and bodies are reflected and projected to its translucent skin. Through this relationship the 'Skin',

37 "The Definition of Symbol." Dictionary.com. Accessed April 7, 2013. http://dictionary.reference.com/browse/symbol.

38 Author's translation. N.K. Gavryushina. 'Philosophy of Russian

Religious Art'. Moscow, Progress, 1993. 259

39 Ibid.,259. 
becomes symbolic.

The relationship between 'Meaningful Skin' and symbol is important for architecture because symbolic direction can add high levels of interpretation and therefore is a path that can define meaning for an architectural project. There is a further, more detailed elaboration on how symbols can be meaningfully integrated into design process in Part Three, the 'Metaphysical Lens'.

\section{Visual - New Definition}

With the ongoing technological growth, the visual domain is characterized by strong relations to physiological space with an emphasis on synthetic vision. Screen-based 'Motion' and interaction bring a new notion of a 'Meaningful skin'. This is important for architecture, as the building can visually interact with its surrounding environment and the human 'Being'.

\section{Design process}

The design process is characterized by the precedence of physiological space over the geometric space, in combination with the conscious understanding and defining of the 'Inner viewpoint'. This gives a meaningful reference point for the visual self-construction of space. Since the 'Inner viewpoint' takes precedence, it positions the architect as an active agent in relation to technology.

\section{Role of the Architect}

As technology expands its influence on human vision, it consumes more attention and time from 'Being' through interactive visual engagement. In order to extensively engage 
the humanity of the designer, conscious non-linear ways of understanding space together with the advancement of visual technology become the optimal solution. Virtuality adds to this aspect and will be discussed in the next section.

\section{Relation to Metaphysical Lens}

The visual aspect is related to space that is physically seen and is often experienced through 'Motion'. It is in a close relation to the physiological, or sensorial, understanding of space and deals with color, texture, and light.

At the same time, architecture deals with an idea something invisible, intangible, that manifests itself physically in the form of a building. Mental visualization is not necessarily static - the form of a mental construct/idea can flux and change, undergoing unlimited transformations in our minds. This brings forward the notion of virtual reality in architecture. 


\subsection{Virtual}

\section{Introduction}

Virtual reality is enhanced by digital technology, although virtual and digital are not synonymous. Nowadays, virtual reality is considered an essential aid for project development. The use of digital technology in many offices enables architects to represent and develop designs intended for construction. It gives the architect power to enhance the experiential aspect of architecture through its visual flexibility as well as animation. Technology facilitates virtual experience.

The "proper meaning" 40 of virtual was defined in 1902 by a mathematician and philosopher Charles Sanders Peirce for Baldwin's Dictionary of Philosophy and Psychology:

Virtual [Lat. virtus, strength, from vir, a man]: Ger. virtuell; Fr. (1) virtuel; Ital. (1) virtuale. (1) A virtual $X$ (where $X$ is a common noun) is something, not an $X$, which has the efficiency (virtus) of an $X$. This is the proper meaning of the word; but (2) it has been seriously confounded with 'potential,' which is almost its contrary. For the potential $X$ is of the nature of $X$, but is without actual efficiency. ${ }^{41}$

Efficiency is the key in this definition. It is also the key word in relation to the concept of French philosopher Gilles Deleuze, who described virtual "[T]hat which is in dynamic tension with the actual in expectancy of its actualization." a2 Pierce's definition is surprisingly exact in relation to digital technology in architectural design, although the term was defined decades prior the use of digital modelling. For example, the animated responsiveness associated with the process of 30 modelling creates

40 "Peirce Dictionary: Virtual." Accessed May 9, 2013. http://www. helsinki.fi/science/commens/terms/virtual.html.

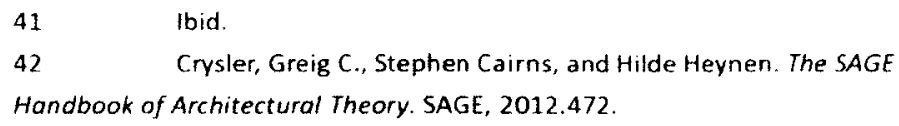




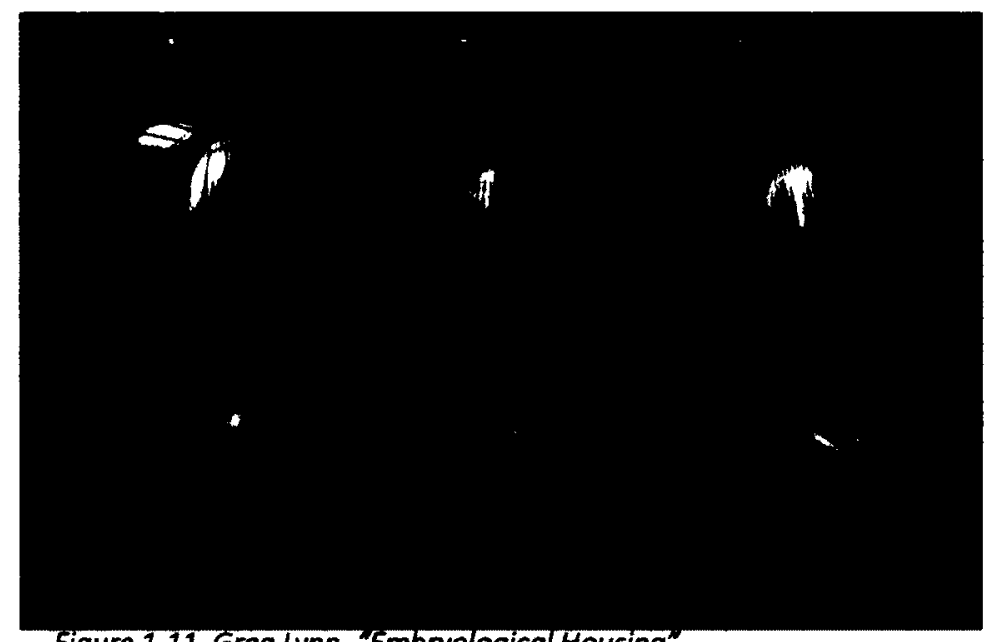

Figure 1.11. Greg Lynn. "Embryological Housing". 
an interaction with the user that is essentially efficient, or is in 'dynamic tension' with the user.

\section{Shifts}

The increased efficiency of technology (not only in direct efficiency such as speed, but also in its effect) has changed the design process for architecture. Picon asserts that prior to the use of digital technologies architectural form was a result of a research process and its beauty manifested in a final equilibrium. ${ }^{43}$ In contrast, a computergenerated architectural form becomes an arbitrary stop in

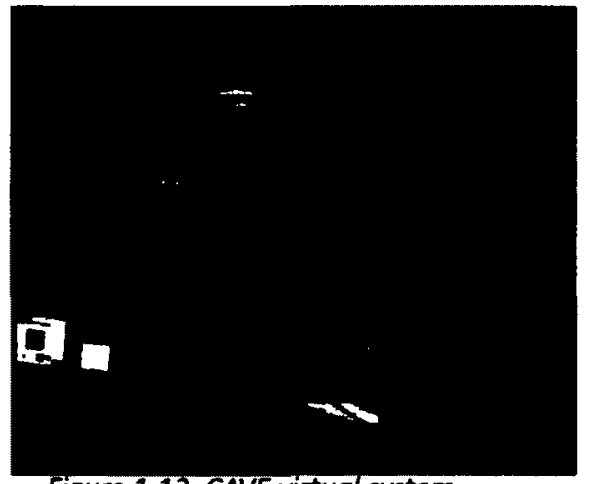

Figure 1.12. CAVE virtual system.

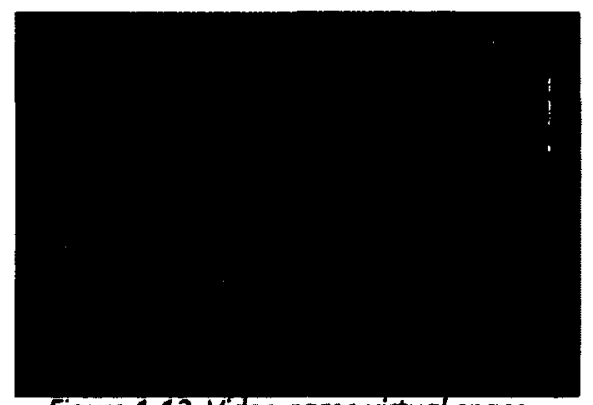

Figure 1.13. Video game virtual space. an endless process of transformations, creating problematic questions in aesthetics and arbitrariness. ${ }^{44}$ To put it succinctly,

When the process is haulted, architectural form becomes similar to an event, although design is more and more comparable to the writing of a scenario. The architectural form literally appears on the screen, while its production from carefully selected parameters looks like the layout of a plot. The similarity between form and event is probably one of the most important effects computers had on architecture. ${ }^{45}$

Through the ease of change in the virtual realm, architecture is 'being' in its virtual manifestation. In this parallel virtual existence, it comes closer to the human 'Being' in the physical world. This affects not only the form, but also the character, of architecture. Greater 'Eventful' flexibility in the design can give more exciting formal results, however, it requires meaning. Otherwise a form becomes "an arbitrary stop in an endless amounts of geometric transformations," meaningful aspect of architecture.

43 Ponte, Alessandra, and Antoine Picon. Architecture and the Sciences: Exchanging Metophors. Princeton Architectural Press, 2003.303

44 Ibid., 304.

45 Ibid., 304.

46 Ibid., 303. 


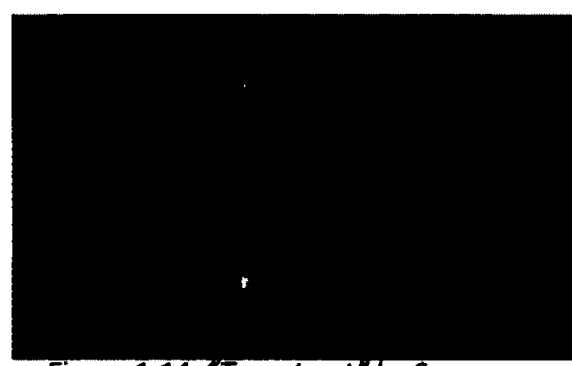

Figure 1.14. "Topostruct" by Sawapan
More so, due to the event-based design process, ef-

ficiency becomes so advanced that the distinction between virtual and real is blurring. This is amplified by the extensive virtual engagement with psyche and visual senses. The efficiency in virtual within the design process can be interpreted on additional levels of psychological interaction and their related cognitive effects, which nowadays can be observed and studied with the rise of neuroscience. An example of a high degree of efficiency is CAVE automatic virtual environment system, where the user moves and interacts within the display boundaries and the correct 3D perspective is displayed in real-time to achieve a fully immersive experience. ${ }^{47}$ Another example of a high level of efficiency is through video games, where the perception of physical reality and virtual reality are blurring. In a research on GTP (Game Transfer Phenomena), studies have been done showing that "with optimal simulations the brain fails to make the distinction between reality and virtual reality." ${ }^{48}$ In relation to design and the advancement of software, more physical qualities are transferred to the virtual reality, thereby influencing the generation of form. An example is a Topostruct study software, which creates an optimized shape based on load and support definitions. Through the development of digital technology, the virtual and physical become closely intertwined.

Virtual reality enables the architect to manipulate visual data, and through technology virtuality can tap into the human imagination to the largest possible extent.

Figure 1.15. A vector ribbon diagram of a molecule. 
Architecture and the sciences develop along parallel lines, often meeting in their common attempt to shape categories of visual perception. And in doing so, they construct notion of subjects and society.

Arie Graafland and Heidi Sohn, 'Introduction: Technology, Science and Virtuality.'49

\section{Systems}

Virtual reality provides a greater engagement with scientific developments and other disciplines. It allows architects to visually conceive previously invisible and complex information.

A good example of this scientific inter-connection is bioinformatics in relation to biology, as described by Timothy Lenoir and Casey Alt. Through the computer-generated visualization of a complex data on protein folds, "a comparison of sequence and 3-D geometry makes it possible

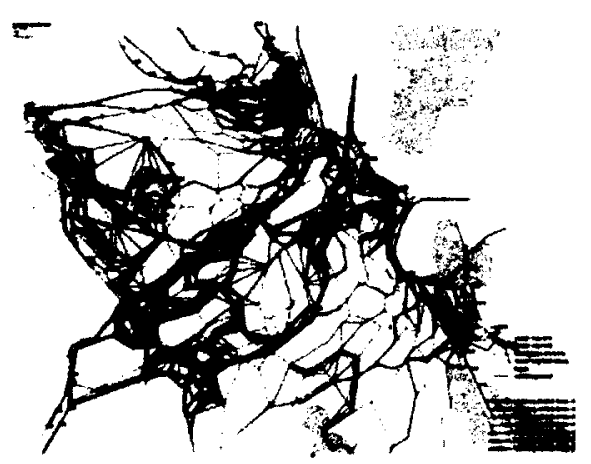

Figure 1.16. A massing location guidance map at the Architectural Association School of Architecture in London. to derive rules or parameters that will subsequently permit the determination of the probability for a given fragment to arrange into a particular regular structure." 50 in this case, the complex non-visual system was manifested virtually through digital technology. This was important for the visualization of originally non-visual data, and consequently has had an effect on the architectural design process. It inspired architects such as Peter Eisenman, Greg Lynn, Neil Denari, and Frank Gehry, and is important in the co-influence of science to their conceptual design framework. ${ }^{51}$ Scientific interchange that has been happening especially with the ability of computers to manage complex data will be further expanding and influencing architecture, since the quality of hardware and computing abilities are increas-

\footnotetext{
49 Crysler, Greig C., Stephen Cairns, and Hilde Heynen. The SAGE Handbook of Architectural Theory. SAGE, 2012.470.

50 Ponte, Alessandra, and Antoine Picon. Architecture and the Sciences Exchanging Metaphors. Princeton Architectural Press, 2003, 323

51 lbid.
} 
ing. A meaningful approach is required for accommodating new discoveries in this area.

\section{Conceptual Fields}

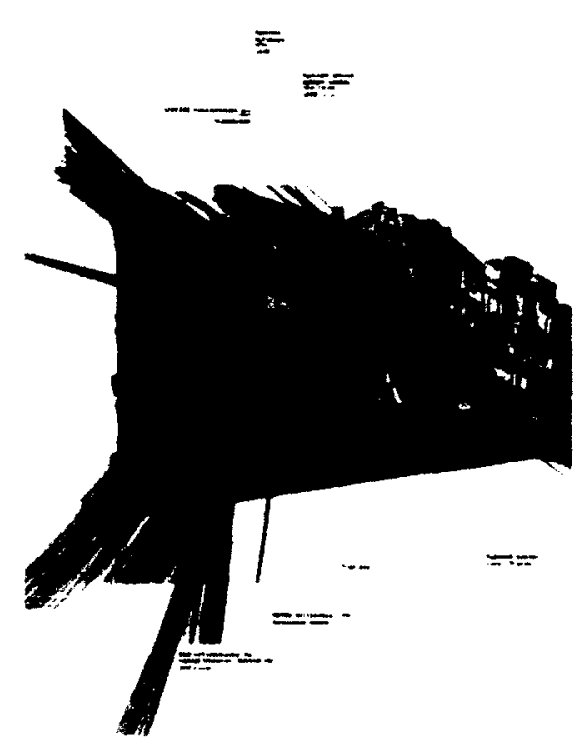

Figure 1.17. An exomple of mapping from data. By Hazel McGregor, Mapping of Moscow's urban infrastructure'.
This interchange between biology and other sciences further enabled diagrams, data, and mapping of abstract information to create so-called "conceptual fields" 52 that also impacted the design process. As the ability to interchange subject areas grows rapidly, architecture is increasingly affected by areas such as global and local politics, military strategic theory, cutting edge scientific research, cultural productions, and world-changing developments in business and technology, among many other things. ${ }^{53}$ According to Graafland, "In the light of what appears to be a new conceptual field characterized by its instability and mobility, by its flexibility and propensity to change, the position of architecture within it opens up interesting avenues of enquiry and interpretation." ${ }^{54}$ In addition, a higher level of inter-activity through internet increases the amounts and speed of informational exchange.

The direction of the design process is dependent on what designers are able to decipher with virtual reality in consideration of our currently multi-influenced nature of architecture. There is a possibility of architecture becoming lost in the conceptual fields and becoming subservient to these systems, simply because of their graphic allure, availability, and ease. An example of this can be seen in the extensive use of mapping data. It can be aesthetically attractive, yet it is still a tool for investigation and discovery, and cannot substitute meaning. Systems and conceptual

52 Crysler, Greig C., Stephen Cairns, and Hilde Heynen. The SAGE Handbook of Architectural Theory. SAGE, 2012.468

53 Crysler, Greig C., Stephen Cairns, and Hilde Heynen. The SAGE Handbook of Architectural Theory. SAGE, 2012.469.

54 bid., 470 
fields can be ways of aiding, structuring, and even inspir-

ing a concept, but the focus should be on the meaningful

framework that these tools can help to build.

\section{Ternary Logic}

In the area of computing, another important step is the potential future use of ternary logic and the development of quantum computers. While a binary system currently used is based on ' $1-0$ ' (true-false), a ternary system is based on '-1, 0, 1' (true-null-false) ${ }^{55}$ and brings the function of digital technology much closer to human thought process. Although ternary (quantum) computer systems have not been put into mass production, according to a scientist Donald Knuth, ternary logic's elegance and efficiency is predicted to bring these computers back into development in the future. ${ }^{56}$ Through having a null factor, which can act as 'unknown' or 'maybe', the logical properties of a ternary system are closer to a the human factor of 'Being'. Scientist Subnash Kak delienated various connections between quantum system as an agent approaching animal intelligence, with one of the elements being self-awareness:

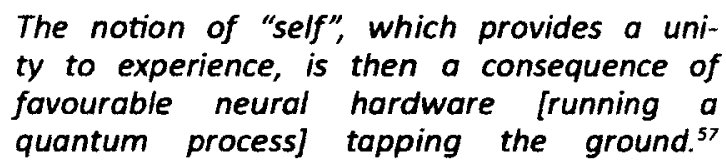

The connections between neural functioning and quantum theory are striking for their potential. The critical shift is having a quantum system act as an agent for design, since it is able to work with enormous amounts of data at

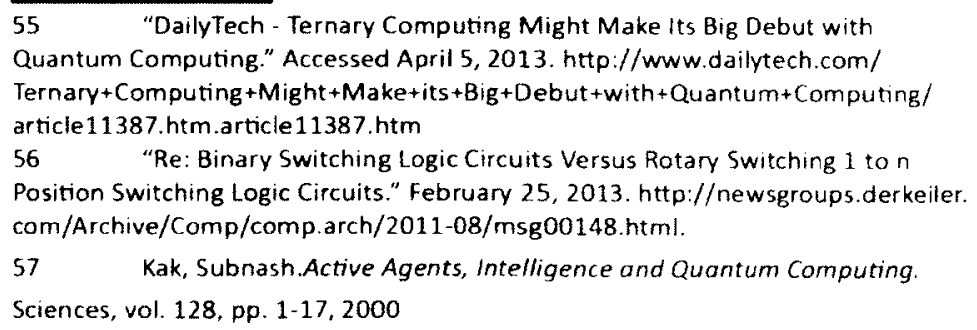


an exponentially faster speed than conventional computing. ${ }^{58}$ Where will this direct the role of the architect?

\section{Virtual - New Definition}

In this thesis, the term virtual is more closely tied to the conceptual, less-physically bound understanding of space and is less physically dependent than the visual aspect. The latter is more closely related to external sensorial space. Efficiency, as part of virtual reality, is foremost applied to 'Being,' and dwells within 'Being,' which is more than any two X's ("common nouns"). This is an important distinction for the definition of virtual within architectural design in comparison to Peirce's definition. Thus digital technology enhances virtual reality.

\section{Design process}

Virtual development undoubtedly leads to the redefinition of the designer's role in relation to a system where $s /$ he remains an active agent and where such a system is unable to anticipate a human solution. Virtual reality and the experience of efficiency by 'Being' help to facilitate this process. A designer can use systems, conceptual fields, and the future ternary computing in order to abstract and/ or visualize complex data. Yet, the ultimate definition of its inter-relationships in architecture should be on the designer's side of the process.

\section{Role of the Architect}

Systems, conceptual fields, and ternary logic are the trends which will be intertwined for framing visionary purposes of architecture. They enable the potential for visionary 
concepts which strongly necessitate the use of, but should not substitute, human imagination. Vision and imagination, in this case, are not optional, but should be considered essential factors for the survival of an architect's role. The additional aspects linking this 'necessary imagination' also find their place in the elaboration of the meaningful framework in the form of 'Narrative'.

\section{Relation to Metaphysical Lens}

For the Metaphysical Lens, virtual contains visual and non-visual aspects, as it is complemented, or augmented by, technology. However, it is a more abstract, as opposed to physiological, notion of 'Being' that can be applied to the design framework. Further notion of narrative events, which will be discussed in the next chapter, can be arranged through their symbolic meaning. 

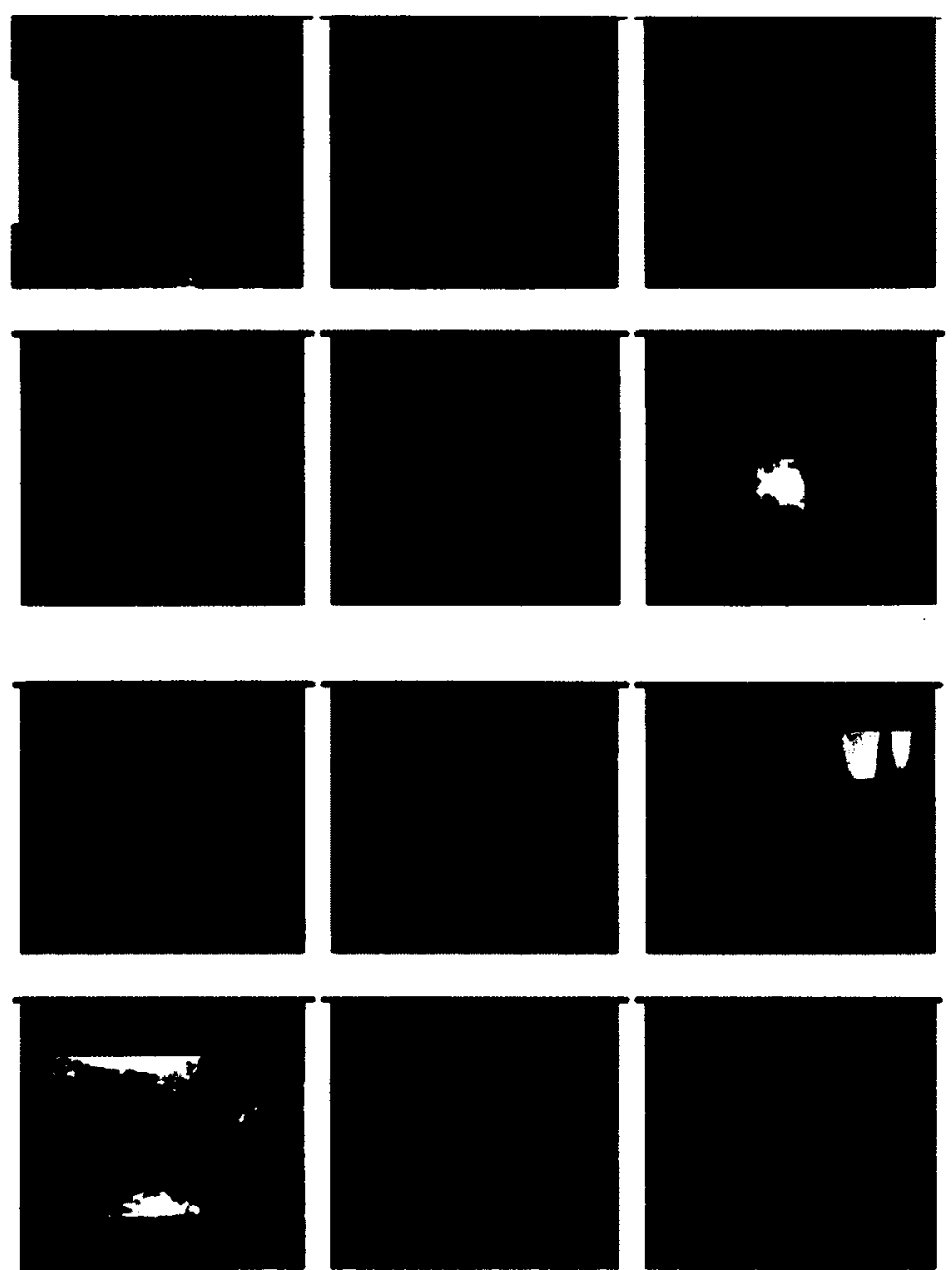

Figure 2.01. Entering a story that follows a physical path from the universe into the space and then explores the effects of different seasons. 
We are trained to work with facts, which is obviously shortsighted in times when communication networks have turned global interconnectivity into a popular theme... Linear processes are replaced by dynamic systems, life is less about answers and more about one's own position and behavior within the surrounding environment.

Maia Engeli, Digital Stories: The Poetics of Communication. $^{59}$

\section{Emotive Narrative}

\section{Introduction}

How should the culmination of virtual information influx be situated in the design process? Increasing prevalence of virtual and visual realities in an architectural design process create the need for a meaningful expression whose process needs to be guided. Current technologies are becoming closer to the psyche of the designer and allow for greater creative manipulation and freedom by enhancing virtual reality. Reliance on a screen-surface relationship involves a highly visual communication. Emotive narrative is an important aspect of this process. In this thesis, narrative is considered in relation to multimedia because (although not fully necessary) it is a vital part of communication in a society where digital technology is prevalent. Visual and virtual intertwine in the development of narrative and multimedia, affecting the communication and the architectural design processes.

Narrative in itself can be considered separate from architecture, as it applies to writing, art, music, and many other fields. Architecturally, narrative can be defined as an emotive spatial association within defined spaces, such as rooms. According to Maia Engeli in her book "Digital Sto59 
ries: The Poetics of Communication,"[A]rchitectural solu-

tions are the buildings that contain the rooms for people to live and work in, and to interact with the world." evolves from memory and imagination. In this section, narrative is considered in order to define its direction within the increasing multimedia environment that combines visual and virtual realms.

\section{Shifts}

A major shift for narrative is the use of multimedia with a highly interactive interface and technological progression towards understanding the body and psyche. This shift occurred with the use of the screen in the Twentieth century, especially with the rise of Television (TV) and computers. Media theorist Marshal Macluhan identified a certain tactility of the media, and " 30 years later with the advent of the internet and instantaneous, real-time connectedness, proprioception (sensorial awareness of oneself) becomes the referential sense for societies in which the computer has become the dominant medium." ${ }^{11}$ This perceptual change is important for architecture, since its message is also often conveyed through multimedia, even when the building is physically built.

Engeli states that "multimedia has the advantage to engage multiple senses simultaneously" while "graphics can explain more complex relations in space than verbal language is able to do." ${ }^{62}$ This connection is reinforced by a higher degree of visual language (i.e. images, movies) being accessible through the internet, which can be interlinked, layered, and vastly manipulated with various

\footnotetext{
$60 \quad$ Ibid., 50 .

61 Various authors. Understanding Media, Today: McLuhan in the Era of Convergence Culture. Editorial UOC, 2011.

62 Engeli, Maia. Digital Stories: The Poetics of Communication. Springer, 
software. This way, images speak to the mind in a natural narrative. Physiological space, virtual and visual realms, and screen-(surface-skin-)-based language bring forward the natural role of narrative. According to Antonio Damasio (an internationally recognized neuroscientist), wordless narrative is natural and is made of imagetic representations of sequences of brain events. ${ }^{63}$ Narrative propelled by images can bring many complex associations. The complexity represented by visual language deals with the immensely rich human psyche, and is the best way to bring out meaning for an architectural design process. With narrative as the driving factor in the design process, it can meaningfully define it as program, circulation, building layout, and interiors.

Images and text

The visual language within narrative is composed of images and text. There is an interesting relationship between them for visually decoding information. According to Engeli, images are received information that provide an instantaneous message, while writing is perceived and requires specialized knowledge to decode the abstract symbols of language. ${ }^{64}$ Abstracted images are more like words, and therefore require greater levels of perception - and when words are bold, they are received faster, more like images. ${ }^{65}$ The prevalence of screens, surfaces, and their interactive nature will create a need for a more visuallybound language, and this will inevitably affect the way architectural messages are composed. The symbolic aspect of perception in this realm is also important and will be discussed further in Part Three.

Two approaches to narrative composition within

63 Frascari, Marco. Eleven Exercises in the Art of Architectural Drawing Slow Food for the Architect's Imagination. 1st ed. Routledge, 2011.67.

64 lbid. 39.

65 ibid., 39 . 
digital media can be used. 1) The construction approach is a build-up process, a strategy of "increasing the dimensions of elements that are placed inside the space." 66 It becomes a process of "filling the space with interpretations, so that, when, finally, the walls are taken away, the definition is stripped and only the meaning remains." ${ }^{\prime 67}$ The process of building up space within the infinity of cyberspace can be defined by points, lines, faces, and objects. ${ }^{68}$ 2) On the other hand, construction can be re-assessed for the formation of something new, where one can

[C]reate a metamorphosis from a given to a desired space. The new space tries to decipher the structure of the original model. The changed space gains significance, by redefining the spatial relations of the elements in a balancing act between the old and the new. The latter attitude respects what is given and transforms it into something new. It does not destroy but expands existing ideas. ${ }^{69}$

These two approaches are ways to define the design process with the narrative framework. Digital tools allow for abstract formation and re-formation of what is originally a non-visual data. It is important to note, that, overall the image is not the architecture, but the message. ${ }^{70}$ An image can reveal aspects that would not necessarily be noticed in a physical building, and its task is to transmit selected information to the spirit, the soul, and the body of the reader. ${ }^{71}$ The direct relationship ("received information") between images and the inner personal world is enhanced by multimedia. This relationship can be expanded vice-versa, when quick image and form generating tools, triggered by movement, words, etc., are effectively used,

\begin{tabular}{ll}
\hline 66 & Engeli, Maia. Digital Stories: The Poetics of Communicotion. Springer, \\
2000.48 & \\
67 & Ibid., 48 \\
68 & Ibid. 48 \\
69 & Ibid.,49. \\
70 & ibid. 42. \\
71 & ibid. 42
\end{tabular}


thereby generating unique images and word stories. The designer's individual uniqueness becomes the force intrinsic to the design process.

\section{Closure}

The future of the narrative is also dependent on additional non-linear processes such as using hyper-links between words and images, and various types of software that conveys information in a non-linear way (such as an interlinked mind-map). This is connected to the organization of the story itself. In the essence of the story one can be "observing the parts but also perceiving the whole."72 According to comics/narrative theorist, Scott McLoud, this phenomenon is called "closure" ${ }^{73}$ and he distinguishes six different types:

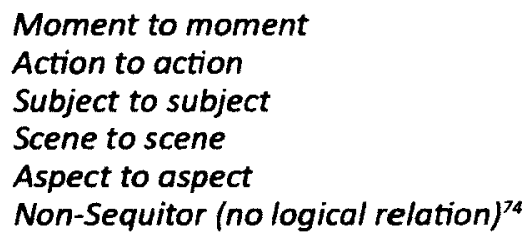

These are important in understanding how the narrative can be composed on various levels.

Space can be created out of nothing or extracted by a variety of actions from an existing condition. The beauty of digital technology for an architectural design process lies in its ability to transform data into a visible form, thus giving architects visual material that is impossible to portray otherwise. As well, a narrative may have its own underlying, abstract framework that brings it closer to virtual reality. Extraction of 'narrative data' is a more complex, synthetic process because it deals with each person's unique story. The next challenge is to be able to 72 Ibid. 61 . 


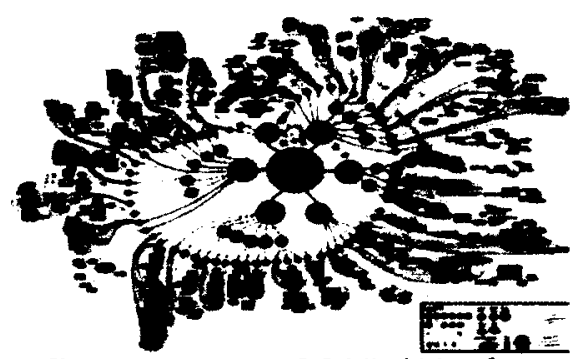

Figure 2.02. LEED v 2.2 Mind Map from Pomodoro Design. It can be used as part of 30 modelling. However, mind maps con be used to creatively map a great variety of ideas. extract a personal story with one of the clients or the programs meant to be on the site. These translations are in the power of the architect, who has the potential to make the types of connections that the computer may not see.

With the immediacy of the design media, and the narrative approach to design, getting the message across to the clients is what becomes highly important. An important reason for a narrative in an architectural design is that it allows for the input of the clients' dreams. ${ }^{75}$ The creation of interlinked individual associations, whether of the architect, or the client, are an important inspirational foundation that can be creatively visualized with the virtual and visual tools, as well as animation.

\section{Emotive Narrative - New Definition}

In this thesis, narrative is defined through the combination of using a designer's awareness of personal events which shaped him/her as 'Being' or which can be related to, in combination with multimedia. In that sense, it is 'Emotive'. Such narrative is constructed through both images and texts, various sequencing methods and closure, in combination with screen technology. Narrative contains aspects of visual and virtual.

\section{Design Process}

Emotive narrative is important for several reasons. In architecture, it can be used for:

- Definition of the meaning, or 'Soul', of the building (as it can connect to the awareness of oneself);

- Definition of the program and functions inside of the building (the events that take place in the building in relation to the composed events of a narrative, as well as a 75 ibid.,47. 
possibility of re-defining the program if it is given beforehand);

- Propelling visual composition (including colours, textures, and lights);

- Enabling a creative use of technology through multimedia with narrative as a driving factor as well as an effective communication tool for propelling the architectural project.

\section{Role of the Architect}

Multimedia and narrative are technologically interconnected in order to enable a high degree of visual and virtual content, thus aiding the architectural design discourse. Multimedia allows architecture to interchange visual content from a variety of sources, as well as disciplines; narrative allows for a meaning within the design process. In this way, the architect is a proponent of personal narrative while technology is an aiding agent.

\section{Relation to Metaphysical Lens}

Narrative can bring a strong meaning to architecture, which is important when considering contemporary vast information influx. Narrative contains both visual and virtual realities, and also contains events that shape the designer as a unique human being. The design, supported by an emotive narrative with spatial configurations is based on light, color, texture, and play of surfaces, as architecture's 'Skin' encapsulates its 'Soul'. A designer's motion through space and/or visual engagement with it through media creates a unique 'Metaphysical lens' through the architectural construct, virtual and physical. 
The orientation to meaning [...] ultimately reaches for truths that are relevant to the subject. Some of these truths require us to go beyond what is directly visible in the shapes of salient structures, bodies, things out in the world. Sometimes we need to build links between the visible structures to get access to things as they are - objects of thought derived from dynamics in the world.

Jan Lauwereyns, Brain and the Gaze: On the Active Boundaries of Vision. ${ }^{76}$

\section{Metaphysiçal_Lęns}

\section{Aristotle and Peirce}

In order to define the term 'metaphysical' for this thesis it is essential to elaborate Aristotle's position with regards to his original definition, as previously noted study of being via being in order to 'link' the importance of the inter-connectedness from physical to psyche. His main understanding of a physical world is actually in its intrinsic connection to the ideal; and that in this world, existence is tied to action." Aristotle's emphasis on physicality is essential for a building design process where the ultimate aim is to have its physical manifestation.

In his philosophy, a human being has no principle limit for attaining knowledge balanced with an ultimate necessity of the sensorial world to attain it. ${ }^{8}$ For Aristotle, in order to know things in fullness one must learn from its physical qualities. ${ }^{79}$ Overall, for him, any knowledge is attained as a result of a sensorial experience while it is impor-

\footnotetext{
76 Lauwereyns, Jan. Brain and the Gaze: On the Active Boundaries of Vision. MIT Press, 2012.244.

77 Version of notes translated by author. Sergey Pimenov 'Plato, Aristotle as part of 'Antique Phiosophy' course. Accessed April 4, 2013. hitp:// predanie.ru/audio/online/istoria-filisofii/

$78 \quad$ Ibid.

79 Ibid.
} 
tant to see the divine mind, which directs everything to a certain purpose. ${ }^{80}$

The importance of metaphysics lies in its essential relationship to the wholesomeness of 'Being' of the human and body through sensorial as well as psychological processes of understanding. The 'Being' in a process of discovery is temporally in 'Motion' and attaining knowledge. The 'Being' as part of a design process, especially with the engaging help of multimedia, is sensorially engaged through the use of visual and virtual reality, as well as narrative (as part of the memory and attained knowledge).

There is a relationship between the Aristotelian approach to 'Being' to a philosophical movement that has been quite influential in the culture of the 20th century. American mathematician and philosopher, Charles Sanders Peirce, who defined the term 'virtual', also created a philosophical branch of pragmatism. It is important for its relationship to the definition of narrative and 'Events' as part of narrative shaping the designer as a person.

In its essence, pragmatism teaches that knowledge is built upon sensorial experience, and experience defines knowledge. ${ }^{81}$ Man brings dynamic changes into the picture of the world and 'Truth', which is dependent on a creative, transformational activity. ${ }^{82}$ The subject of knowledge is interested in the process, passage, and results of attaining knowledge, ${ }^{83}$ which is reminiscent of Aristotle's philosophy. A man is shaped by the heritage of his experiences. ${ }^{24}$ This way, there are different approaches to attaining knowledge and one and the same reality is perceived differently by each person. ${ }^{85}$ It is significant for the definition of a unique

\begin{tabular}{|c|c|}
\hline 80 & Ibid. \\
\hline 81 & Version of notes translated by author. Sergey Pimenov 'Charles Sanders \\
\hline \multicolumn{2}{|c|}{$\begin{array}{l}\text { Peirce. William James.' Accessed February 15, 2013. http://predanieru/audio/ } \\
\text { online/istoria-filisofi/ }\end{array}$} \\
\hline 82 & Ibid. \\
\hline 83 & Ibid. \\
\hline 84 & Ibid. \\
\hline 85 & tbid. \\
\hline
\end{tabular}


'Metaphysical Lens' for a design process, because individual knowledge adds uniqueness of each designer.

For Peirce, the action itself is based on beliefs, which is on another level from knowledge. ${ }^{86}$ The relationship between knowledge, faith, and action is in the following states: ${ }^{87}$

1) Doubt - The state of indecision, unsatisfaction, abnormality or sickness, which is hard to be in. It is a state of internal anxiety, from which a person tries to escape;

2) Exploration - Stage of fight for attaining a new belief (where repeated facts are important);

3) Belief, or Faith - A calm and pleasant state, a certainty to act upon, which evolves into a habit. Truth is a knowledge of faith, doubtless at a particular moment of time.

The importance of these states lies in relation to narrative, and in the individual growth that is shaped by unique events, especially through the state of exploration. As well, it gives a narrational definition into where the designer 'stops,' raising questions such as - Where does 'faith' solidify? Or should it solidify? In relation to technology this is especially important. The continuous exponential technological growth demands a continuous renewal of these states.

In relation to Peirce, the principal aim of this thesis is to form a 'faith' for action within a design process. This way, a designer is an active creator in his work that transforms the surrounding environment. The knowledge of the experiential aspect of faith is important: to know something means to know it through experience. This is important for a further relationship between sign and symbol that strongly ties to the virtual reality, where efficiency of an object ' $X$ ' can be translated through a symbol. According to Peirce,

$86 \quad$ Ibid

87 Ibid.




$$
\begin{aligned}
& \text { II]n consequence of a habit (which } \\
& \text { term I use as including a natural } \\
& \text { disposition)...l call the sign a Symbol. }{ }^{28}
\end{aligned}
$$

So, a symbol is individually interpreted through faith, or belief that evolves into a habit, and its meaning is defined individually through experience. ${ }^{89}$ This will become important for deciphering spatial arrangement in relation to the interpretation of symbols in the project in Part Four.

Based on the explorations of the Visual, the Virtual and the Narrative, a 'Lens' is constructed and can be unique for each designer.

Definition of Design Process - based on Visual, Virtual, and Narrative

Visual aspect of experience is closely tied to a physiological understanding of space. In Aristotle's and Peirce's philosophies, the experience through 'being' for attaining knowledge is related to visual interaction with the physiological space.

Virtual aspect plays the role of a more abstracted meaning and understanding of symbols, which, according to Peirce, are individually interpreted.

Narrative is the events and the experiences of life in time that is enhanced by visual and virtual, that shape the designer as a human.

88 "Peirce's Theory of Signs." Accessed February 10, 2013. http://www. clas.ufl.edu/users/jzeman/peirces_theory_of_signs.htm.

$89 \quad$ Ibid. 


\section{Role of the Architect}

\section{Visual}

In relation to the visual, the architect consciously adapts an 'Inner viewpoint' in precedence of a geometric schema. The physiologial spatial aspect enriches architecture by pushing the use of a variety of colors, textures, and lights. Reverse perspective, Self-Constructive space, become part of the 'Inner viewpoint' preceding in importance to the architecture as an object. Physiological aspect of space becomes an Inside-out design based on Light, Color, and Texture.

\section{Virtual}

In relation to virtual, the 'Metaphysical Lens' enables the architect to change their perception of an object to a higher level of understanding by knowing and challenging one's own understanding of previous experiences and habits, in this case, is also strongly related but not limited to, technological growth. Virtual becomes virtual Animation, the experience of the architectural model through motion versus architecture as an object. Systems, Conceptual Fields, become symbolized through data and systematic visualization within digital technology.

\section{Narrative}

Narrative becomes composed of events shaping the architect's life, which define the program and meaningful elements within the design and design process as a whole. Choice is at the discretion of the an Architect, since each person's narrative is unique. 
The 'Metaphysical Lens' in the design process will allow for the architect to shape the design in relation to architect's personality. It is shaped by unique life events and a person's recollection of them. This is also vital for architectural design, because it brings constructive meaning to the design process and provokes seeing things beyond convention, as it is self-adaptable and not a locked system. The architect can take the 'Metaphysical Lens' and, with a high engagement of both the 'soul' and the environment, use it to transform and enrich the design process (and architecture), hopefully, making the world a better place. As well, it presents a rich potential for greater and better use of multimedia and technology. 


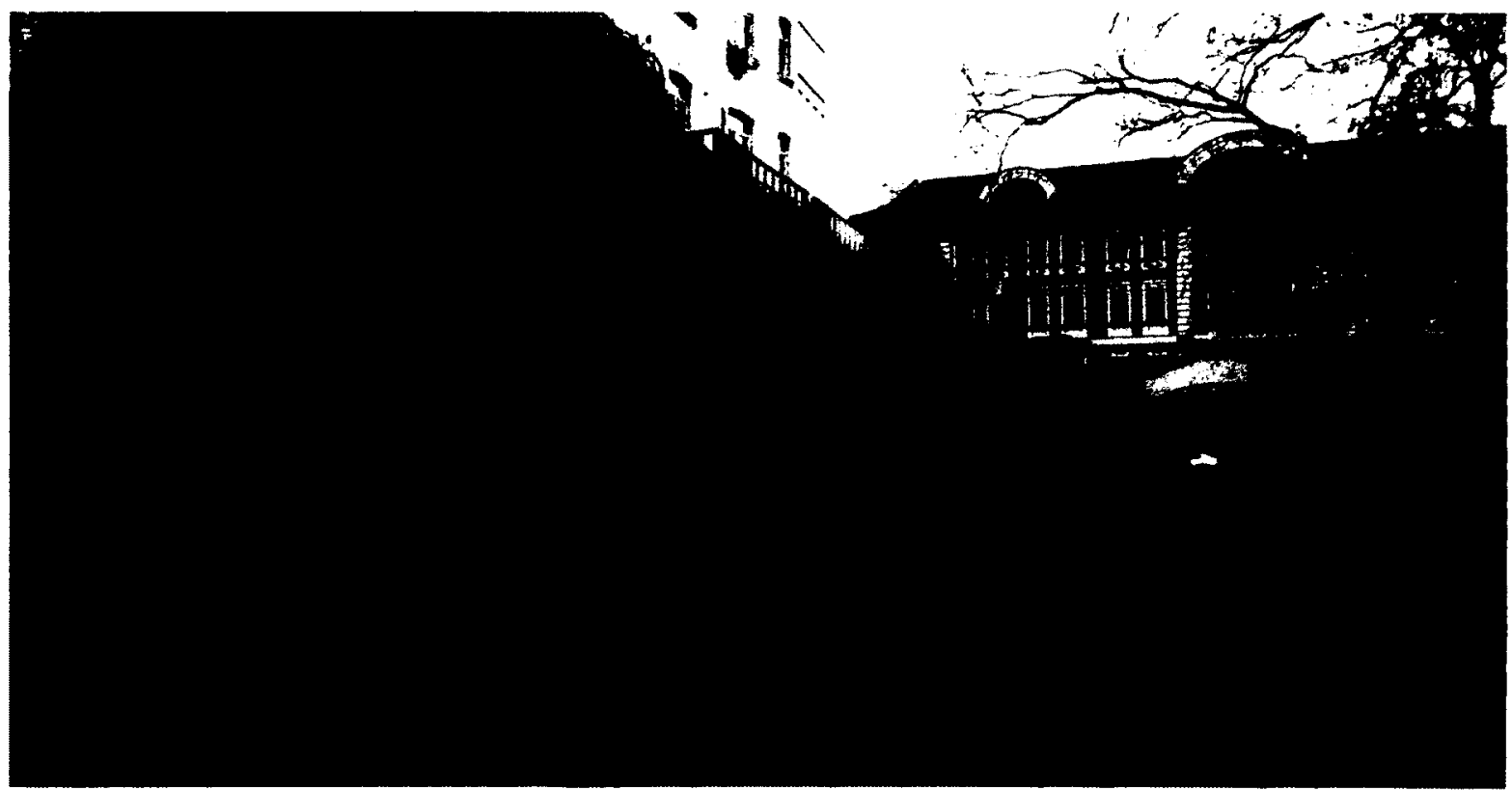

Figure 4.1. View from inside of the Sretensky Monastery towards the current entry. A stone Cross has been installed near the site in commemoration of New Martyrs. 


\section{Project._Church of the New Martyrs.and Confessors of Russia on the Bloogd,that. is on Lubyankạa”.}

The choice of this project is based on a personal previous search for expression of a design process in relation to the vastness of the human soul, especially in relation to the growth of 'Being' under difficult conditions. Especially, after reading Alexander Solzhenytsyn's 'The Gulag Archipelago' I had bigger questions. Why did some people chose to conform to the values of the Communist regime, and others chose to die, even though everyone faced similar threats?

I was looking for an architectural design that could meaningfully incorporate and use the quality of inner human strength. Through research on the subject of the design process itself, the issue of increasingly extensive technological control emerged, leading to the design of the 'Metaphysical Lens'. The ultimate exercise dealing with the various factors of control and qualities of the human soul has manifested into this church project.

\section{Sretensky Monastery - Site.}

\section{Brief History}

Sretensky Monastery was founded in 1397 and is one of the most ancient monasteries in Russia. ${ }^{90}$ It was founded to commemorate the miraculous event of the meeting of the Vladimir Icon of the Mother of God, which saved Moscow from the invasion of a Tatar conqueror Tamerlan. ${ }^{91}$ Prior to a battle, while Muscovites were intensely praying for Theotokos (Mother of God) to for their survival in the face of a formidable enemy, he saw a dream with 90 "Sretensky Stavropeghial Monastery." Accessed May 9. 2013. http:// www.pravoslavie.ru/english/sretmon.htm. 
the Mother of God commanding him to leave the land. The vision was so horrifyng to him that, even though being a successful and fearless conqueror, he immediately fled. ${ }^{92}$ Historians still make guesses at the causes of his retreat. ${ }^{93}$ The only major change to the territory occurred during the escalating persecutions of Christians in the early Soviet history, where the monastery was closed in 1925 and reopened in $1991 .^{94}$

\section{Soviet Union Period}

The Church is dedicated to New Martyrs who suffered in the 1930's under the dictatorship of Joseph Stalin and former NKVD (The Peoples Commissariat for Internal Affairs). This dark period of Soviet history is disproportionately overlooked, considering an enormous amount of victims - over 2.6 million people ${ }^{95}$ - who lost their lives for not conforming to the Soviet regime. In 1925 the Secret Services of 'Cheka' ('Committee Extraordinary'), the predecessor of the KGB (Committee for State Security) moved onto the premises, destroying a large part of the monastery's ancient buildings. Also, on its territory, shootings were held. ${ }^{96}$ This piece of land is literally soaked through with the blood of thousands of New Martyrs during that the terrible epoch.97 By 1991, the same year as the break-up of the Soviet Union, the sole surviving cathedral of the 'Vladimir Icon of the Mother of God' on the monastery's territory was returned to the Russian Orthodox Church..$^{98}$

\footnotetext{
$92 \quad$ lbid.

93 lbid.

94 lbid

95 Translation by author. "Why Are New Martyrs Being Forgotten?

Orthodox lournal 'The Garden of Learning'" Accessed May 9, 2013. http://www. nsad.ru/articles/pochemu-zabyvayut-novomuchenikov.

96 "Sretensky Stavropeghial Monastery." Accessed May 9, 2013. http:// www.pravoslavie.ru/english/sretmon.htm.

97 ibid

$98 \quad$ Ibid
} 
Figure 4.3. Map of Moscow, Russia. (NTS) The city is ring-based, the inner (smaller ring), called the 'Garden Ring' is made up of green, public boulevards, which are popular public spaces. The site is located next to Rozhdestvensky (Resurrection) Boulevard. 


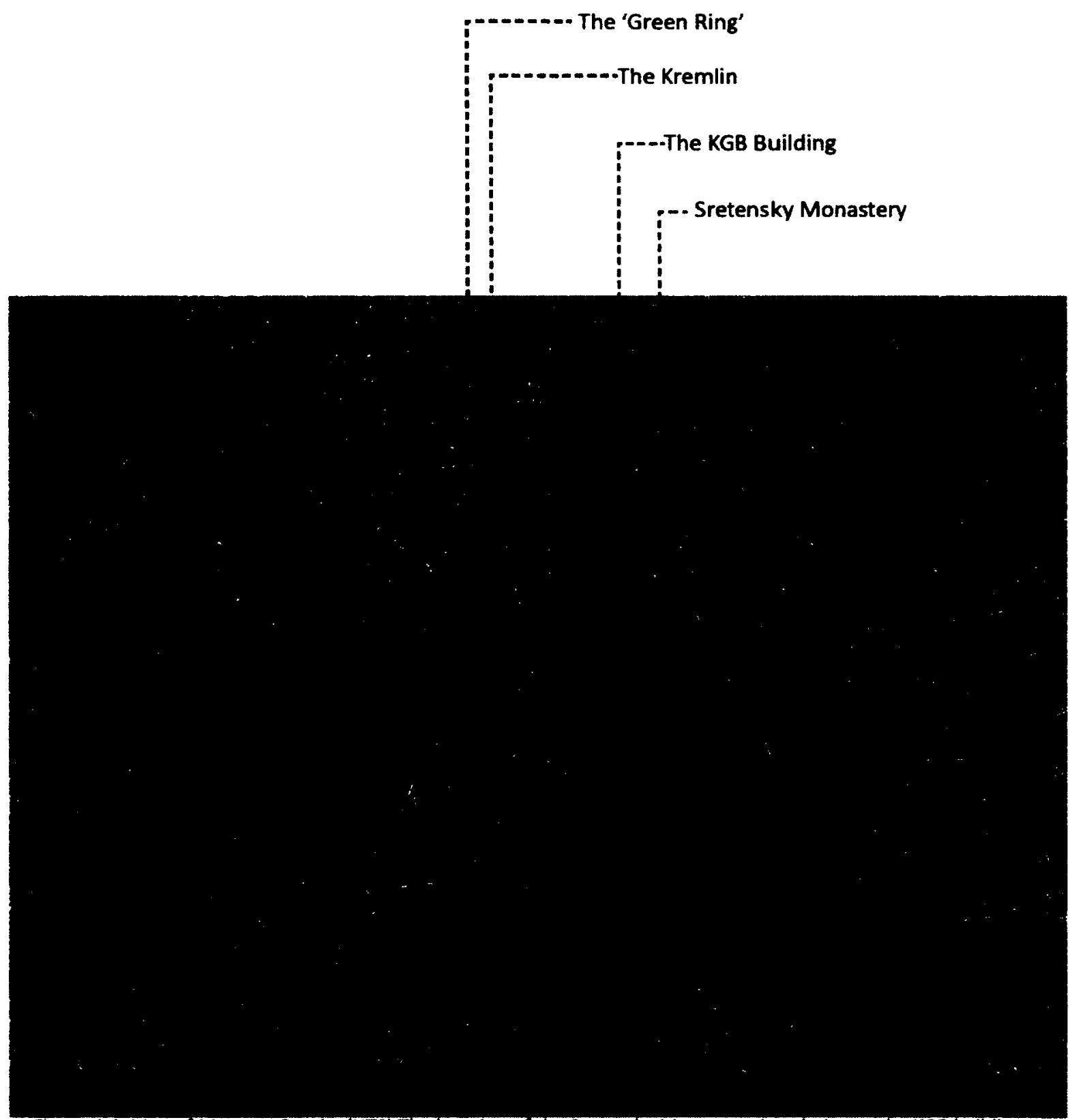

Figure 4.4. Map of Moscow, Russia. (NTS) The location of the Sretensky Monastery in relation to the KGB building and the Kremlin. A close proximity - about 500 meters - to the former NKVD facilitated the events that happened on the site. 


\section{After The Soviet Union \\ Population}

The monastery's territory houses $\mathbf{4 0}$ monks, as well as clergy. It also houses Sretensky Monastery High Orthodox College. It is a popular place, virtually holding a central character in an Orthodox Christian life in Russia.

\section{New Martyrs}

By January 2011, 1774 martyrs were canonized, based on found archives ${ }^{99}$ from the Soviet era. The definition of 'New Martyrs' encompasses all believers who died for their faith (in Christ) in the 20th century, whether canonized or not. ${ }^{100}$ The impact of these events is underrepresented in the media, books, and recorded historical memory of the population. In addition, there is access to only about one-twentieth of the archival collections. ${ }^{101}$

\section{Virtual Presence}

Sretensky monastery, besides being an important spiritual centre, is also an important publishing house and has a significant online presence.

\footnotetext{
99 Translation by author."News-National Archive of Administrative Ministry of Sverdlovskaya Oblast. Ekaterinburg." Accessed May 9. 2013. http:// gaaoso.ru/page/?id=556\&n=316

100 Translation by author. "How Many Repressed People in Russia Suffered For Christ? Orthodoxy and the World."Accessed May 9, 2013. http://www.pravmir. ru/skolko-repressirovannyx-v-rossii-postradali-za-xrista/.

101 ibid
} 


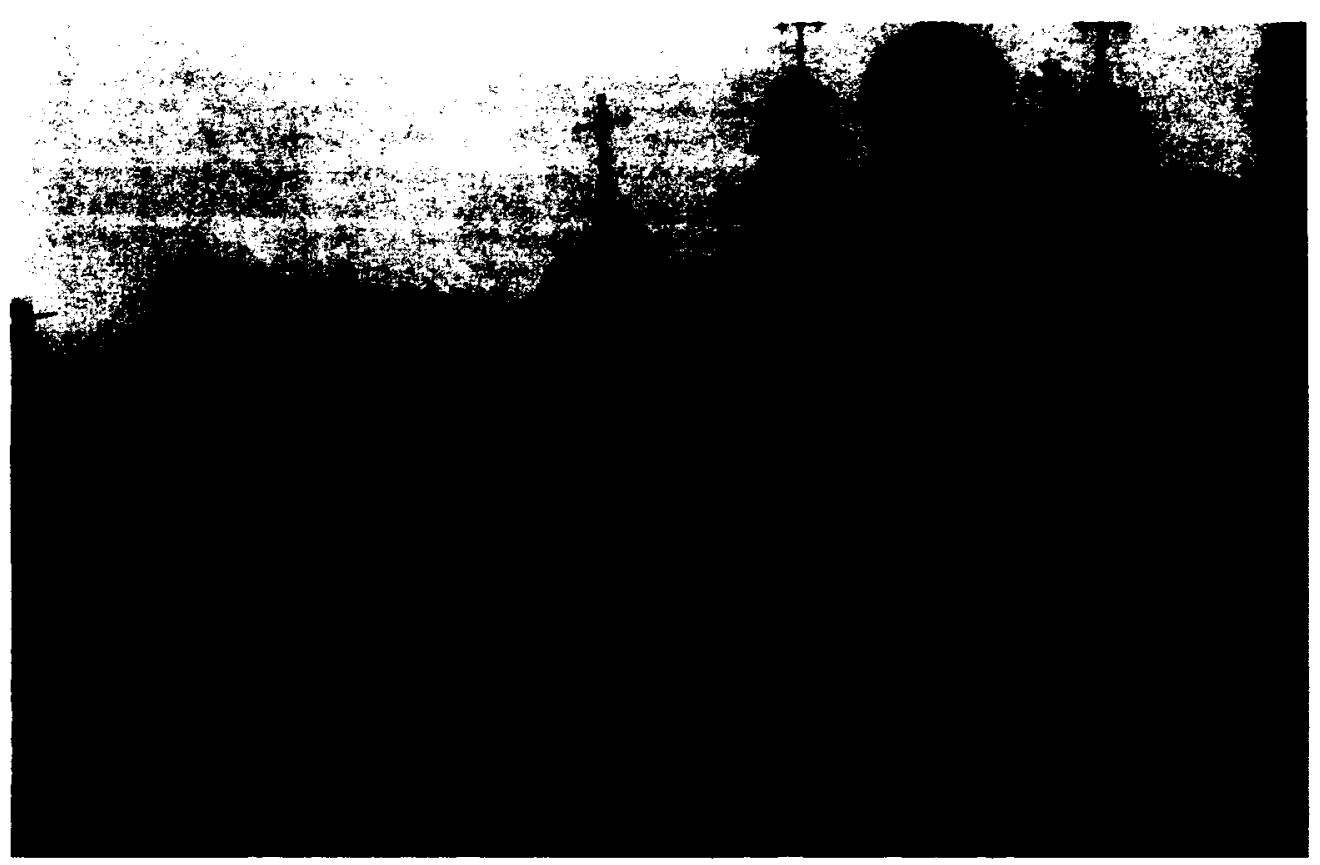

Figure 4.5. Image of destruction of the Sretensky monastery in the late 1920's.

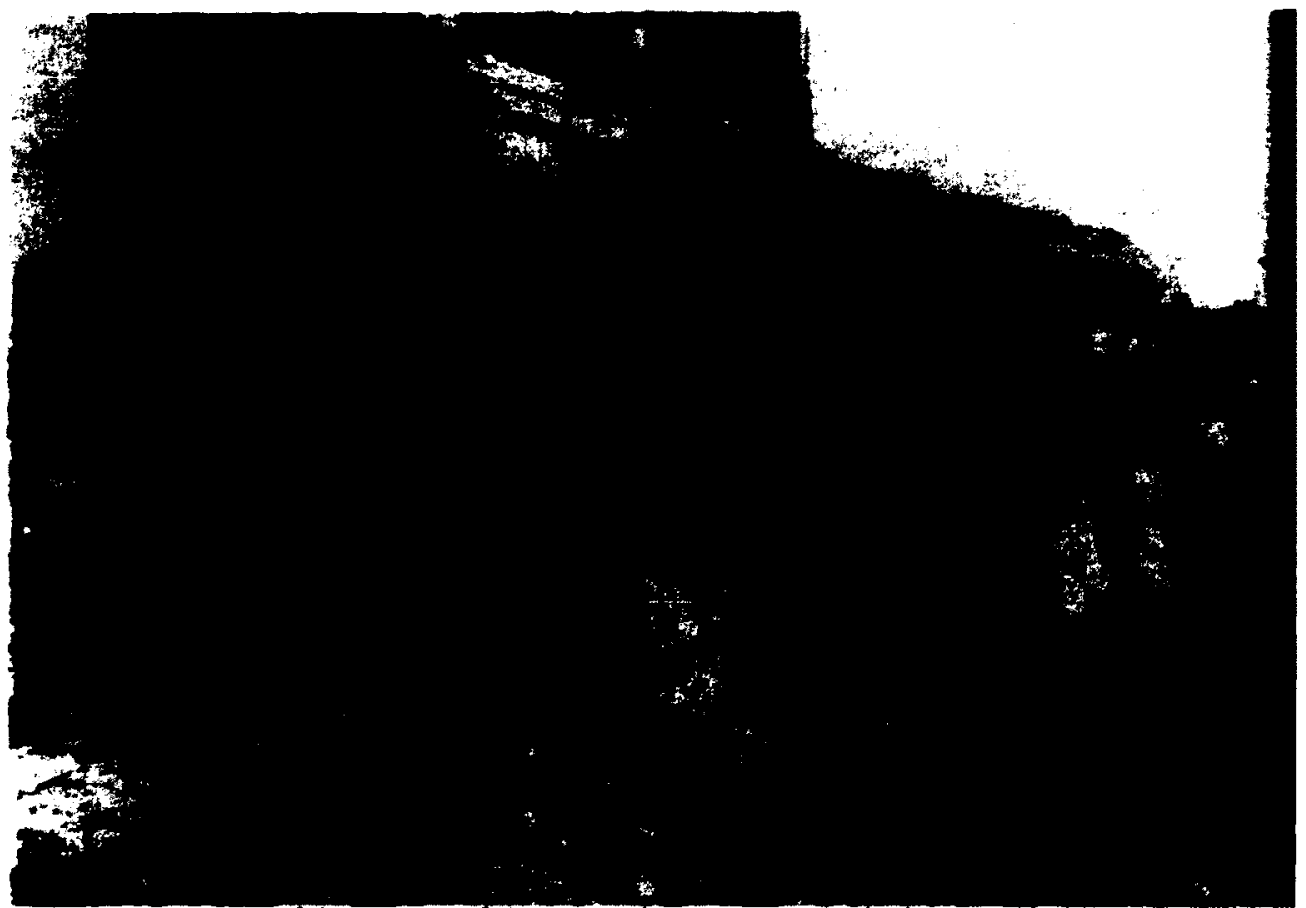

Figure 4.6. Image of destruction of the Sretensky monastery in the late 1920's. Demolition of a small church dedicated to St. Mary of Egypt. It has not been rebuilt. 


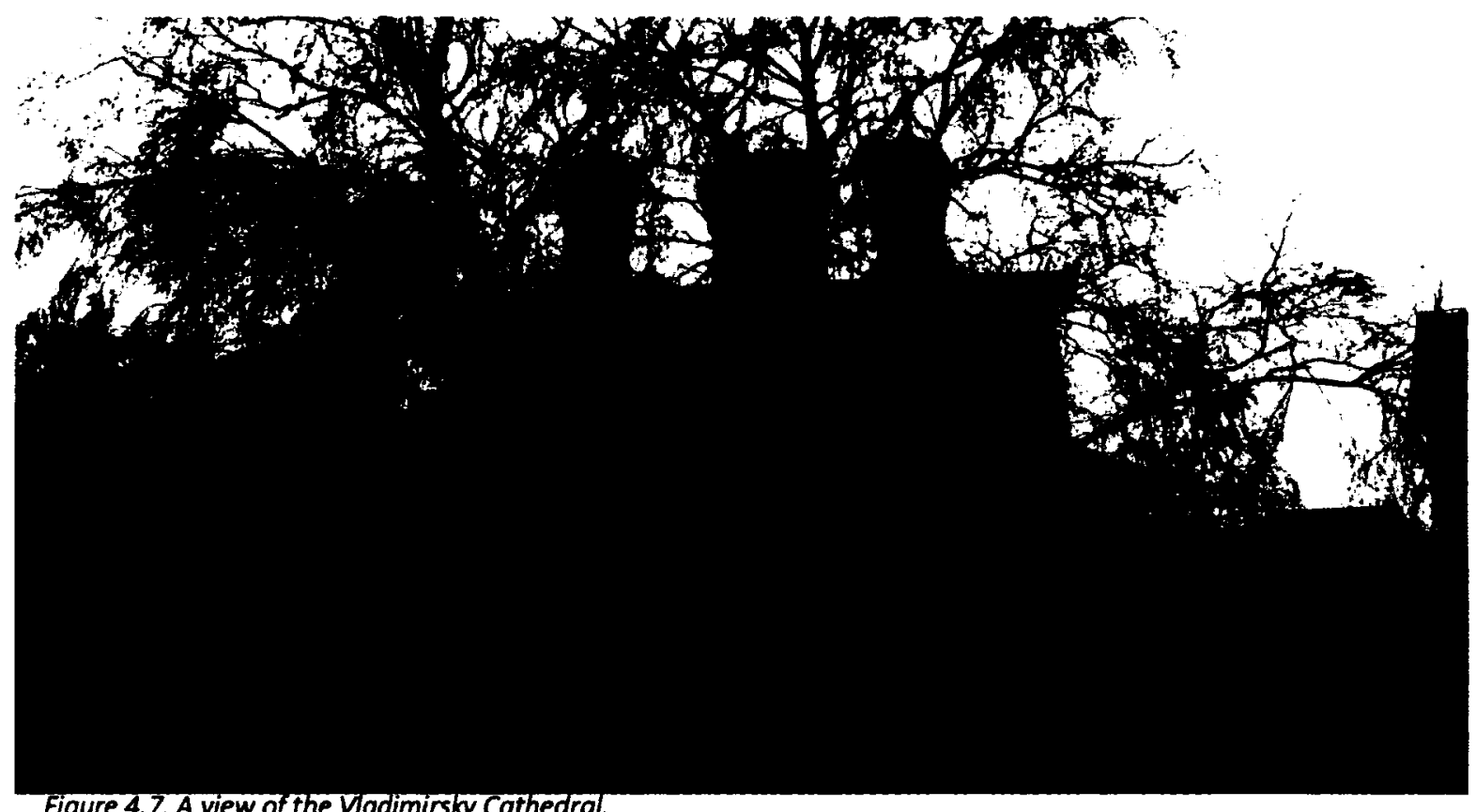

Figure 4.7. A view of the Vadimirsky Cathedral. 


\section{The Orthodox Church in Russia - Symbolism}

According to architectand Orthodox Christian priest Konstantin Kamyshanov, the current basic church model, watered down from the previous configurations, is 'Altar-Church'. ${ }^{102}$ The narthex, traditionally for those who are not yet baptized, and those in strong repentance, does not function this way anymore - instead, everyone stands where they wish. ${ }^{103}$

Although there are some canons with regards to the 'Holy of Holies', the Altar space, the actual configuration will be interpreted using the narrative approach in relation to the story of Christ, the unbroken spirit of the Martyrs, and events experienced in life that led to their personal growth in relation to God.

There is a high regard and respect for the traditional church architecture amongst the population in general. However, in consideration of functional, aesthetic, and semantic levels, important questions are being raised that are not being answered architecturally. ${ }^{104}$

\section{Current Issues Within Context}

\section{Function}

There are number of issues regarding modern urban conditions in Russia in relation to Church architecture. The traditional planning of functional areas cannot accommodate the demands of the population. ${ }^{105}$ There are not enough churches to accommodate the amount of people coming; often, as is the case with Sretensky monas- 
tery and their central functioning church, people are lined up outdoors and follow the services through the sound of the speakers. Kamyshanov characterizes the architectural direction in relation to contemporary Orthodox church architecture in Russia as a standstill in crisis. ${ }^{106}$ According to him, amongst many parts of Orthodox art (contrary to the current trends) in the past centuries church architecture was always distinguished by creative innovation.

\section{Issues stemming from the Repressions}

Nowadays, the Russian context in this regard is quite interesting. The events of the 20th century have forcefully disconnected centuries-long religious culture amongst generations. It is also important to note that in comparison to current times, the Church was integrated into the society which re-inforced its common ideals. Now, the Church and the state are separate; the latter is in its own difficult process of creating an ideological framework. ${ }^{107}$ This contextual disintegration brings forward important questions, especially for the architect, who is placed to solve mega-problems that normally are solved with a collective societal effort. ${ }^{108}$ 


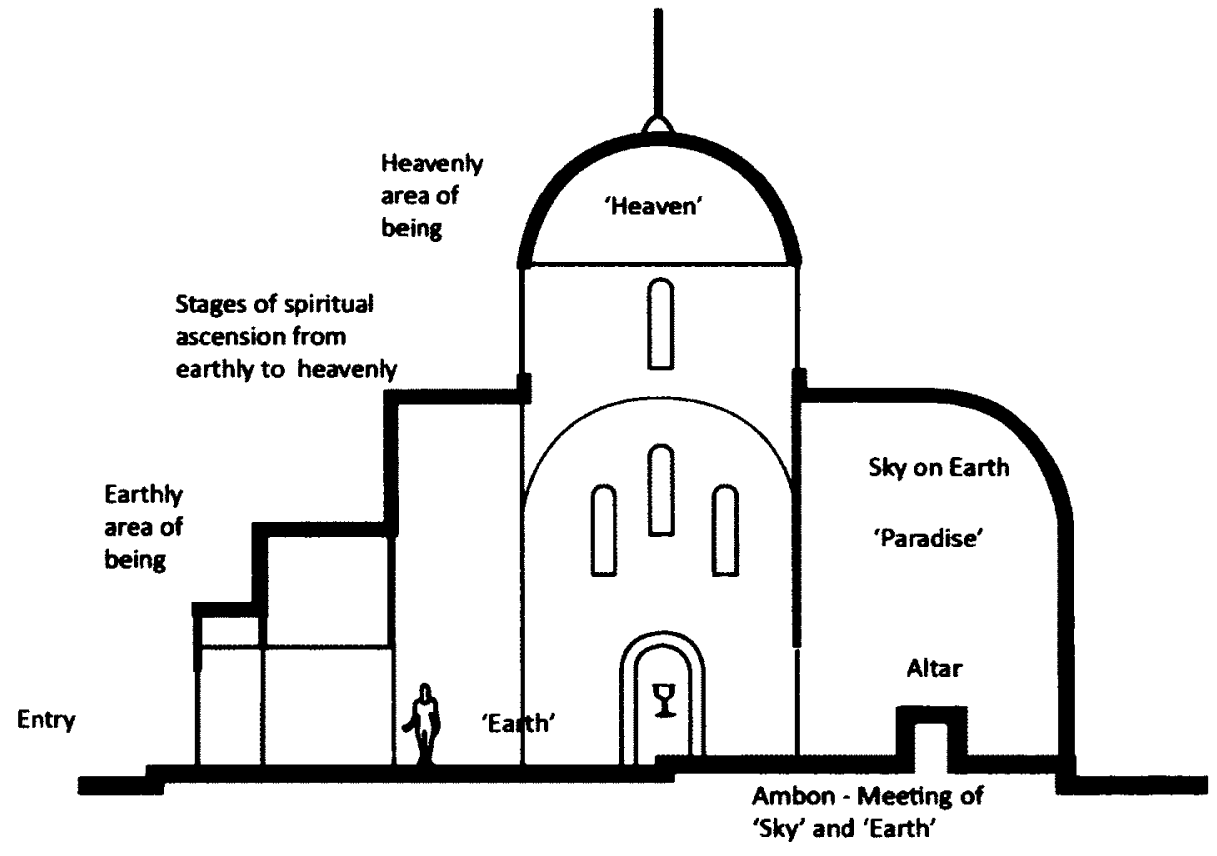

I

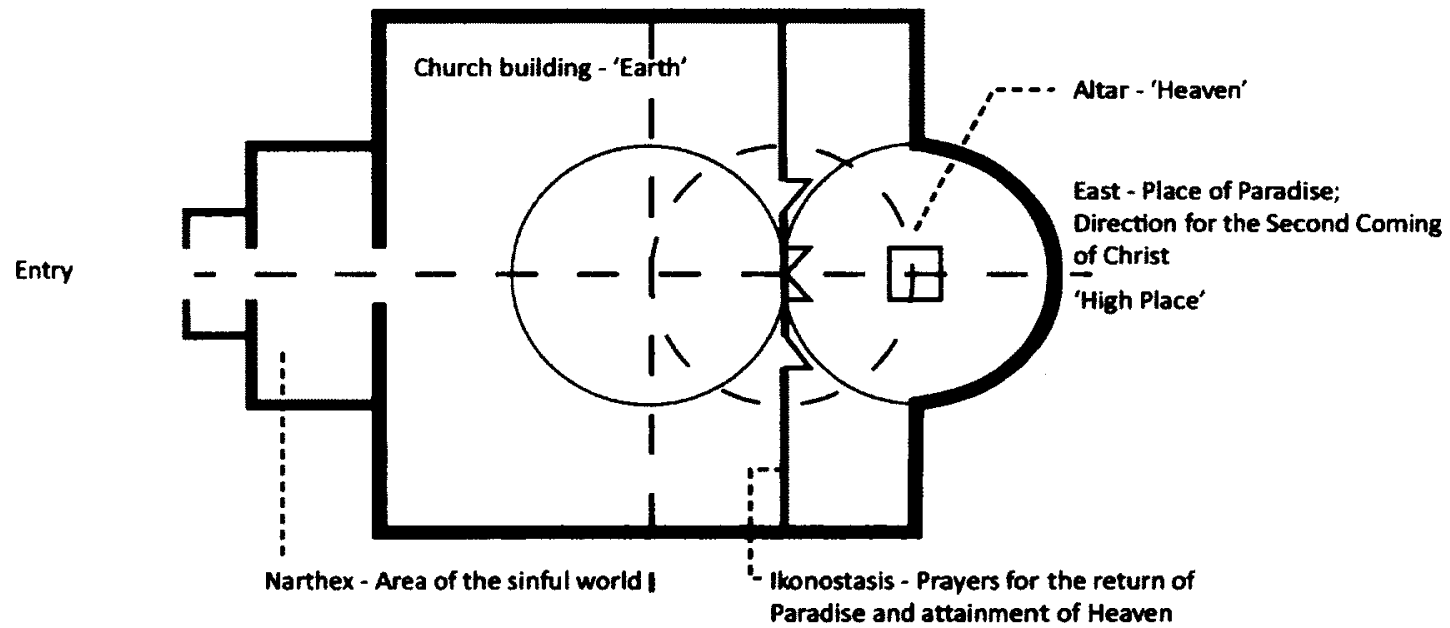

Figure 4.8. A Schematic Model of an Orthodox Church with Symbolic Meaning of its Elements. The spiritual reality of the church is expressed in its architecture through symbols. On the basis of a dogmatic teaching of the Orthodox Church about the future transformation of heaven and earth into the Kingdom of God, the church overall symbolizes the Heavenly Kingdom, the returned paradise to humanity. In terms of planning, the Altar is 'Obraz' ('Image') of Paradise - the spiritual world descending towards people on earth. Middle part of the church symbolizes heaven, earth, universe - renewed through reconciliation with the spiritual world. ${ }^{1}$ 


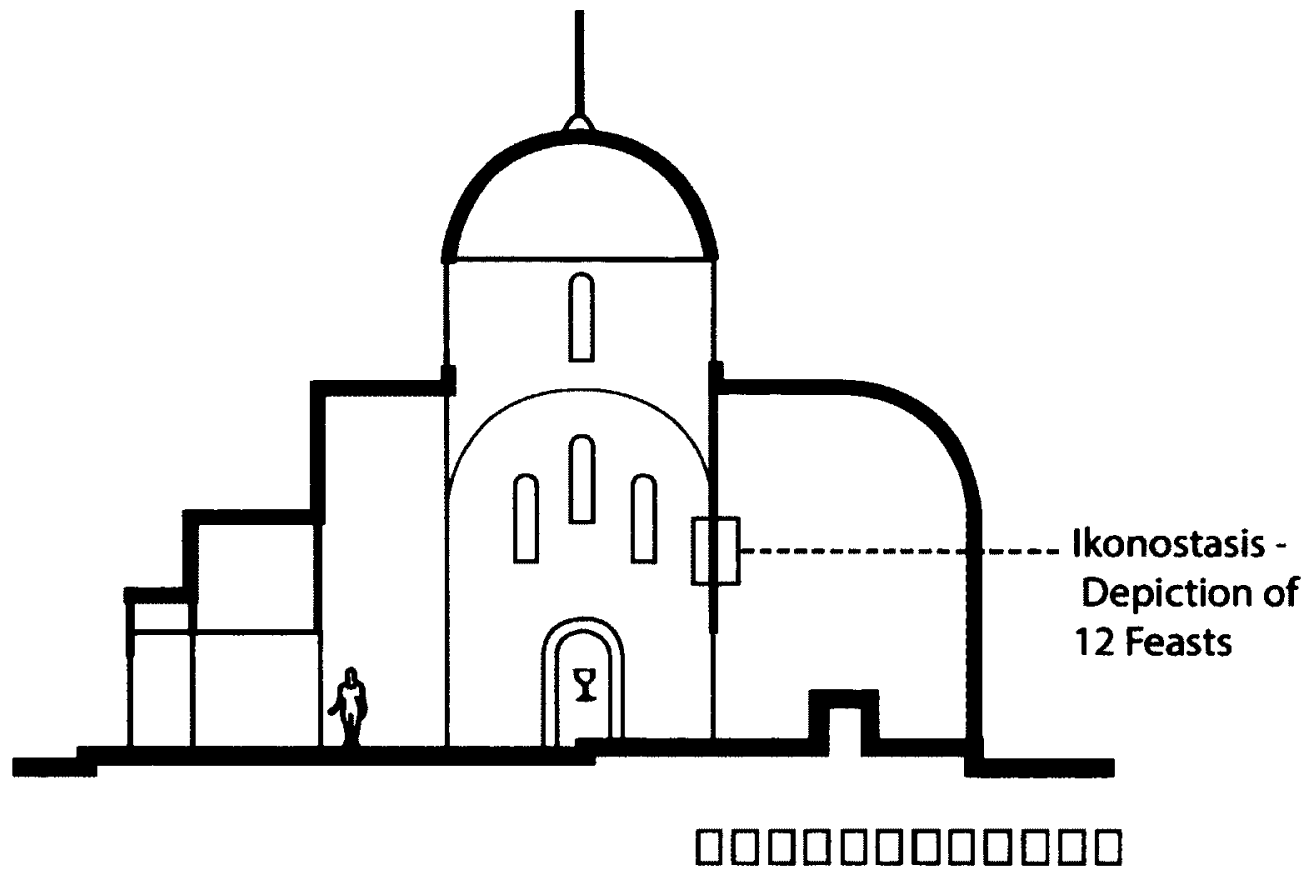

12 feasts represent the story of Christ<smiles>CC(C)(C)C</smiles>

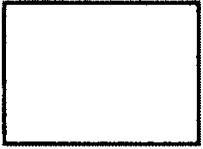

Agony

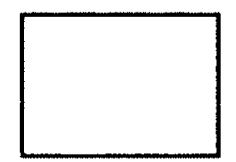

Hope

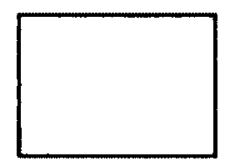

Love

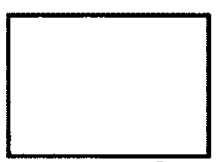

New Life

Chosen personal events of spiritual journey

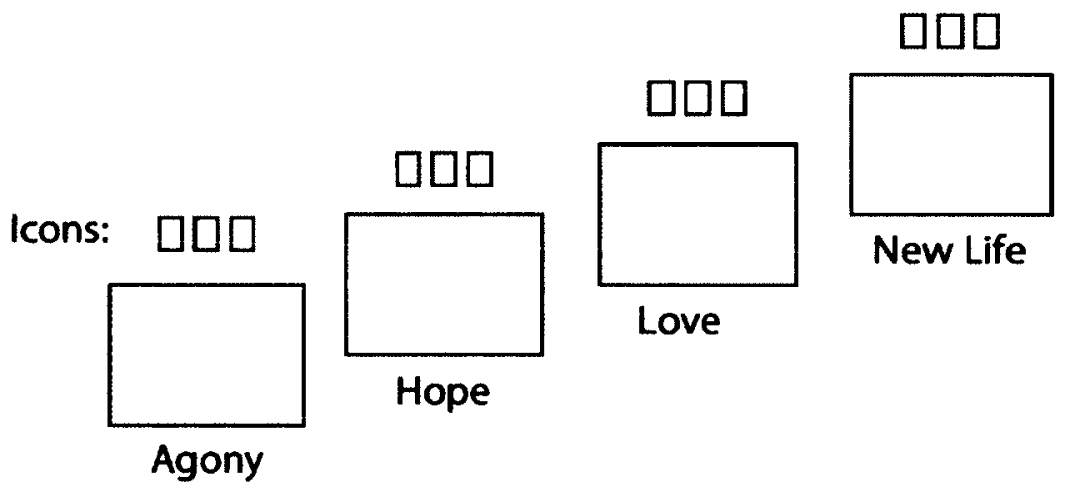

Figure 4.9. Reassessment of symbolic spatial organization of the church architecture with 'Metophysical Lens'.

1 Translation by author."News-National Archive of Administrative Ministry of Sverdiovskaya Oblast. Ekaterinburg." Accessed May 9. 2013. http://gaaoso.ru/page/?id=556\&n=316. 


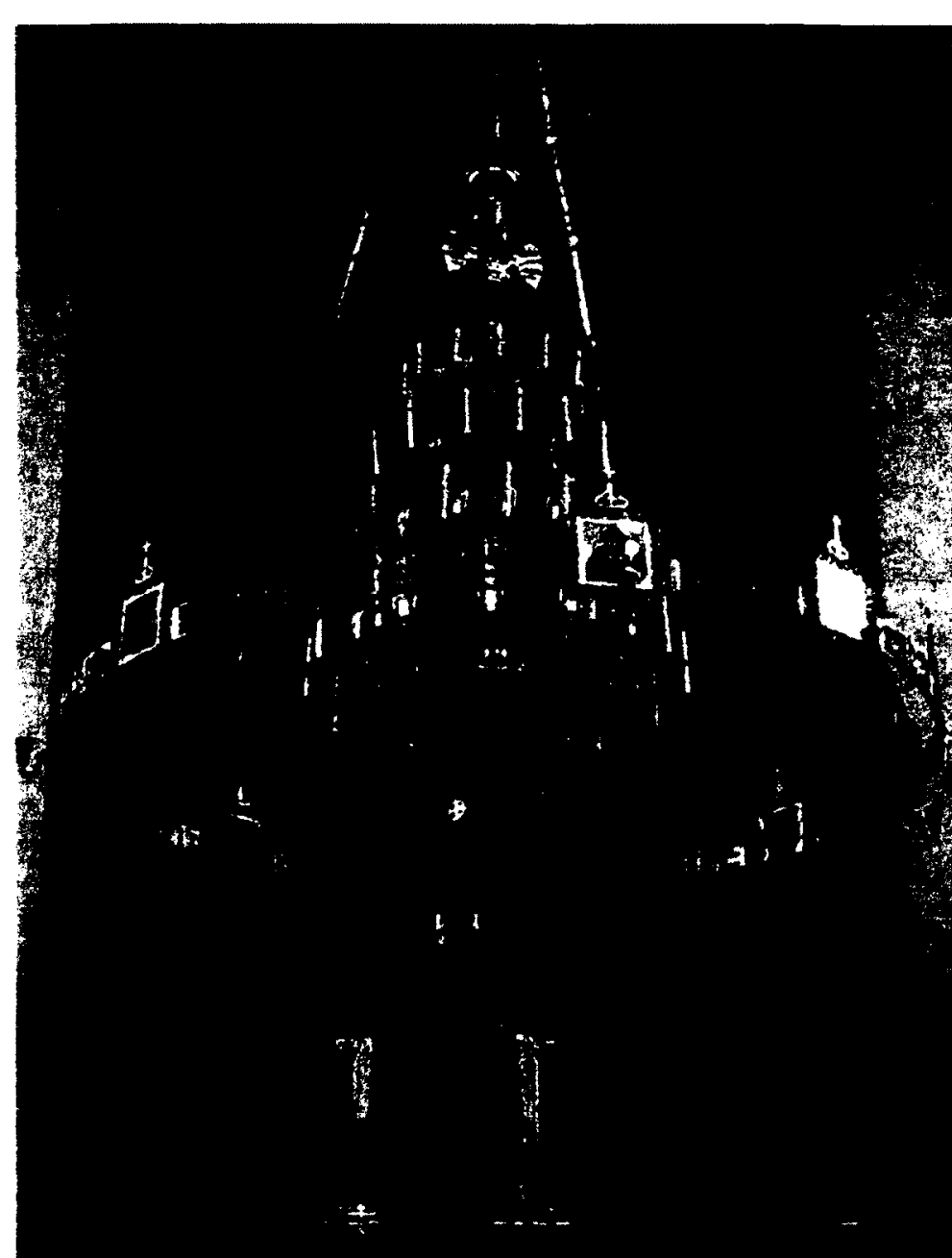

54

Figure 4.10. An example of iconostasis. 


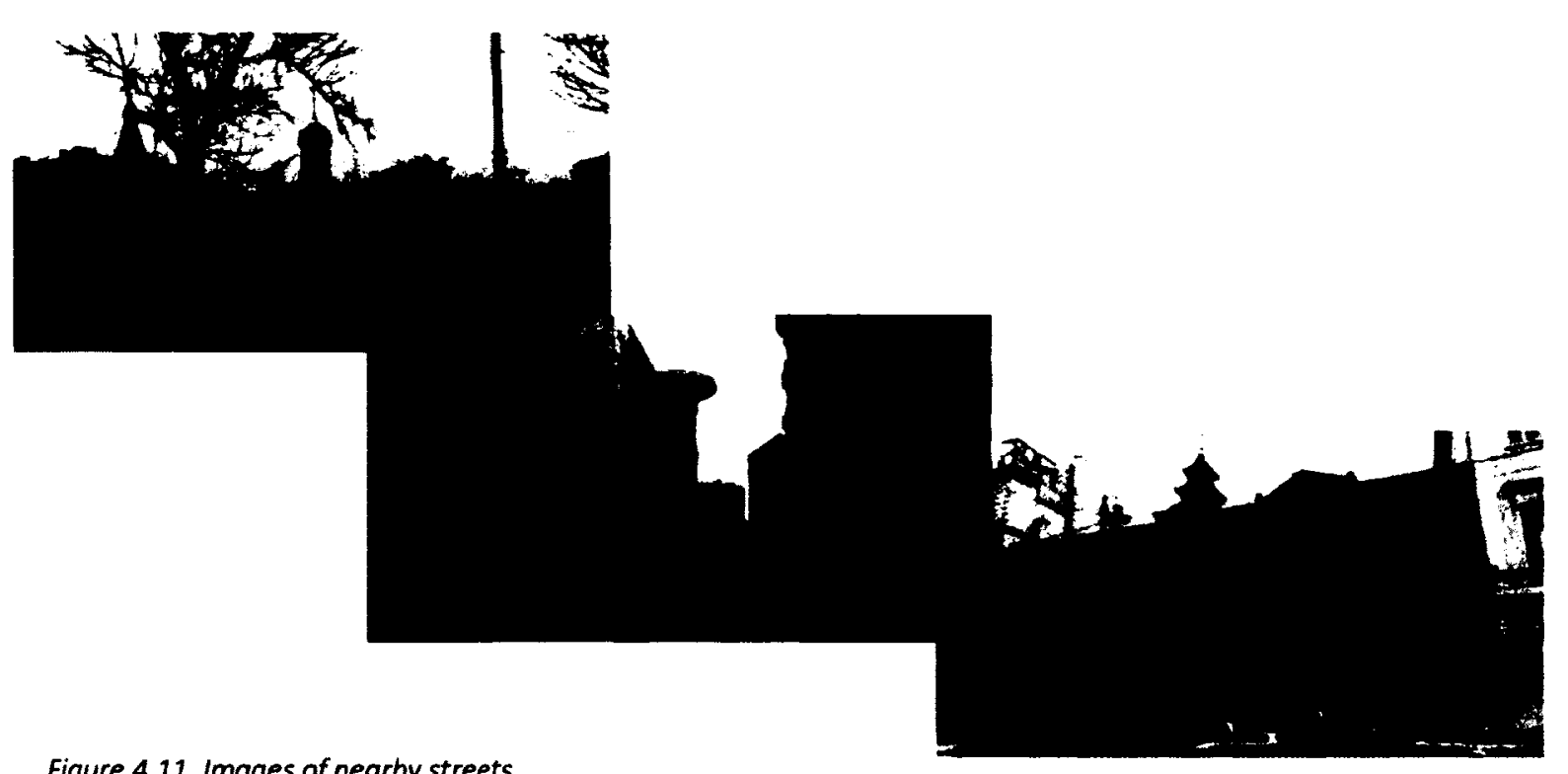

Figure 4.11. Images of nearby streets.

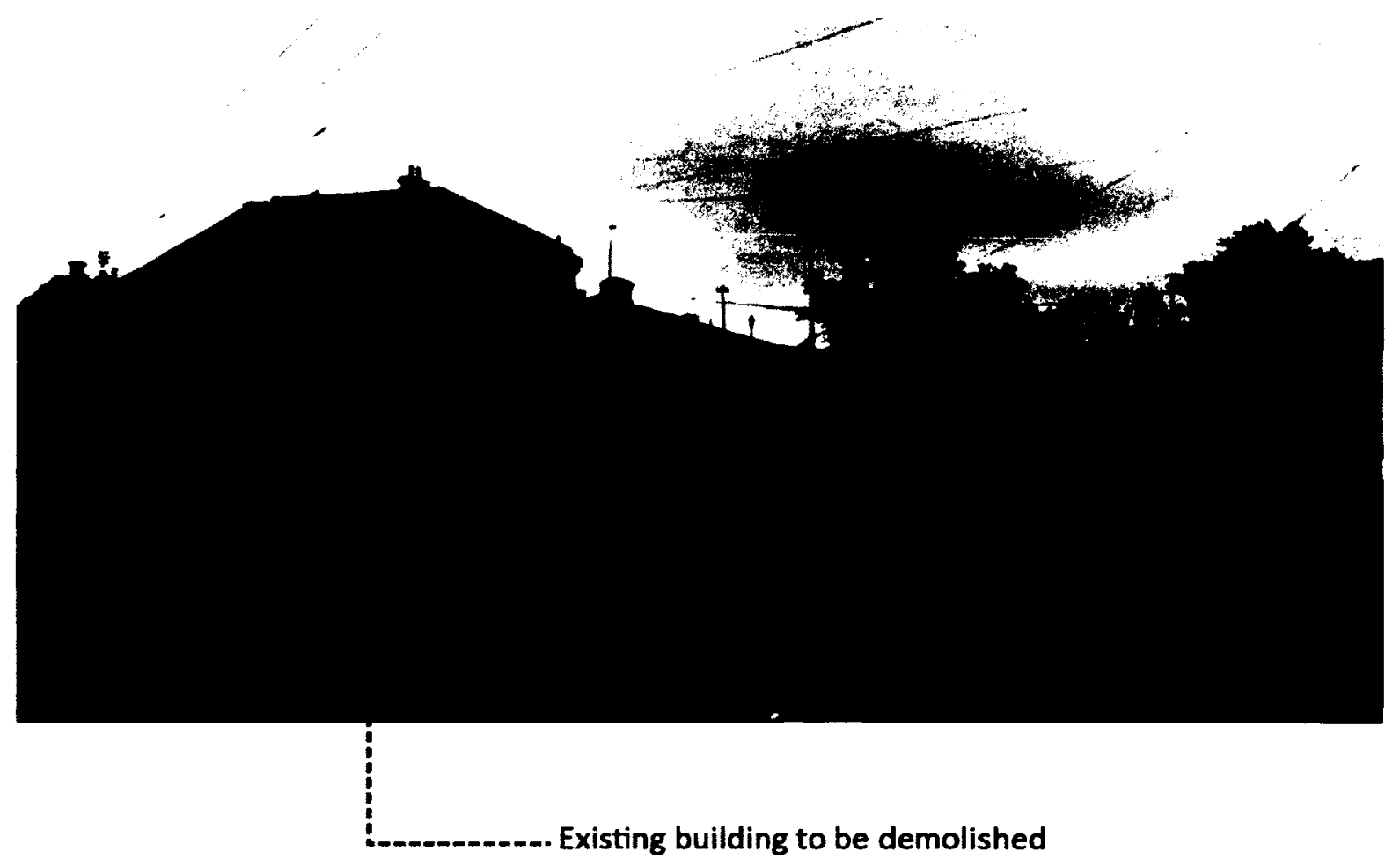

Figure 4.12. Street-view of the site. 


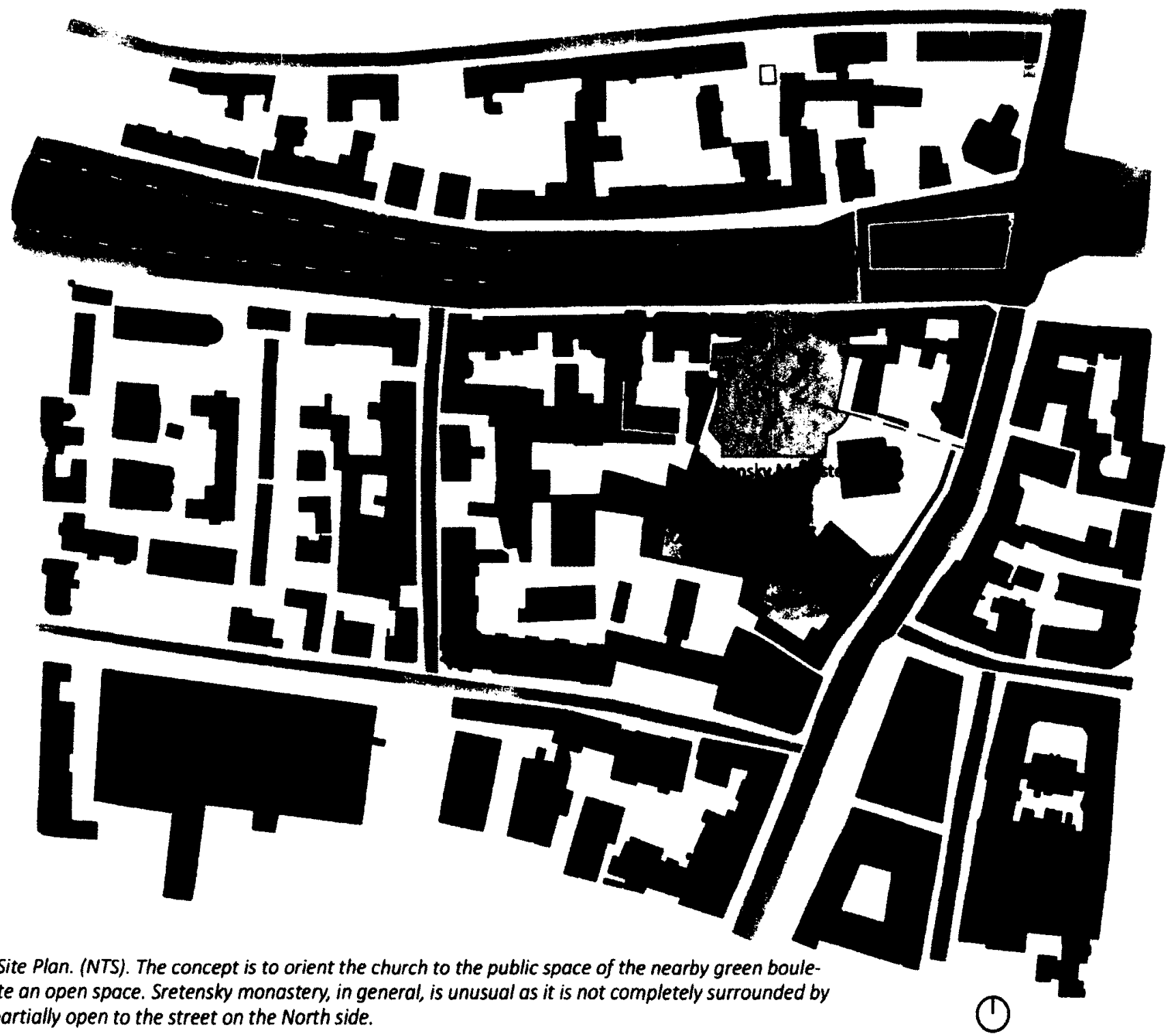

vard and create an open space. Sretensky monastery, in general, is unusual as it is not completely surrounded by a wall and is partially open to the street on the North side. 


$$
\int_{1}^{1}
$$




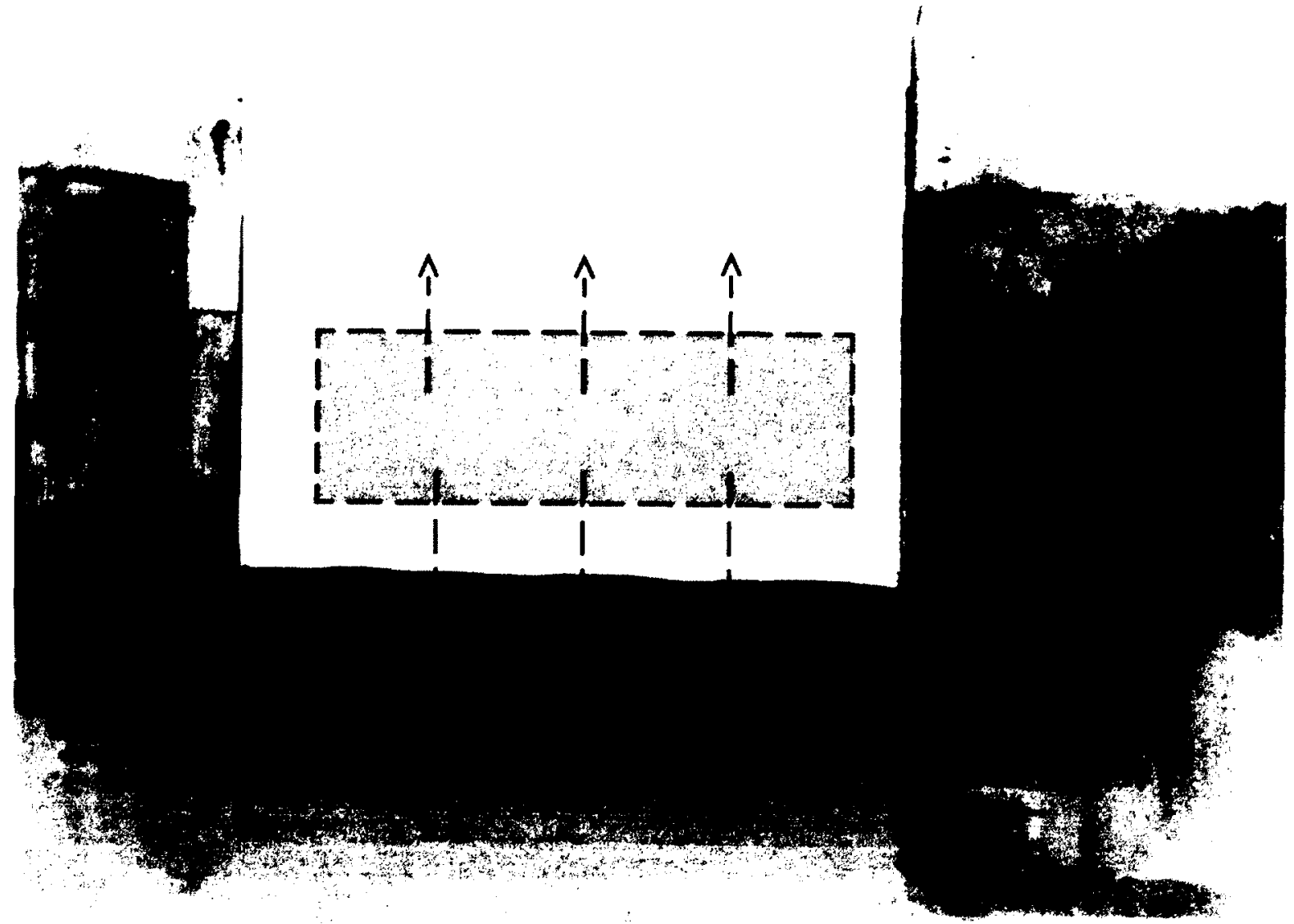

Figure 4.15. 'Memory' Concept Section. The concept is Reconciliation of the memory of the past events and the story of Christ with the general public and educating it through gradual introduction of combined narratives. The earth of the site is 'sacred', and the project signifies the relationship with it. 

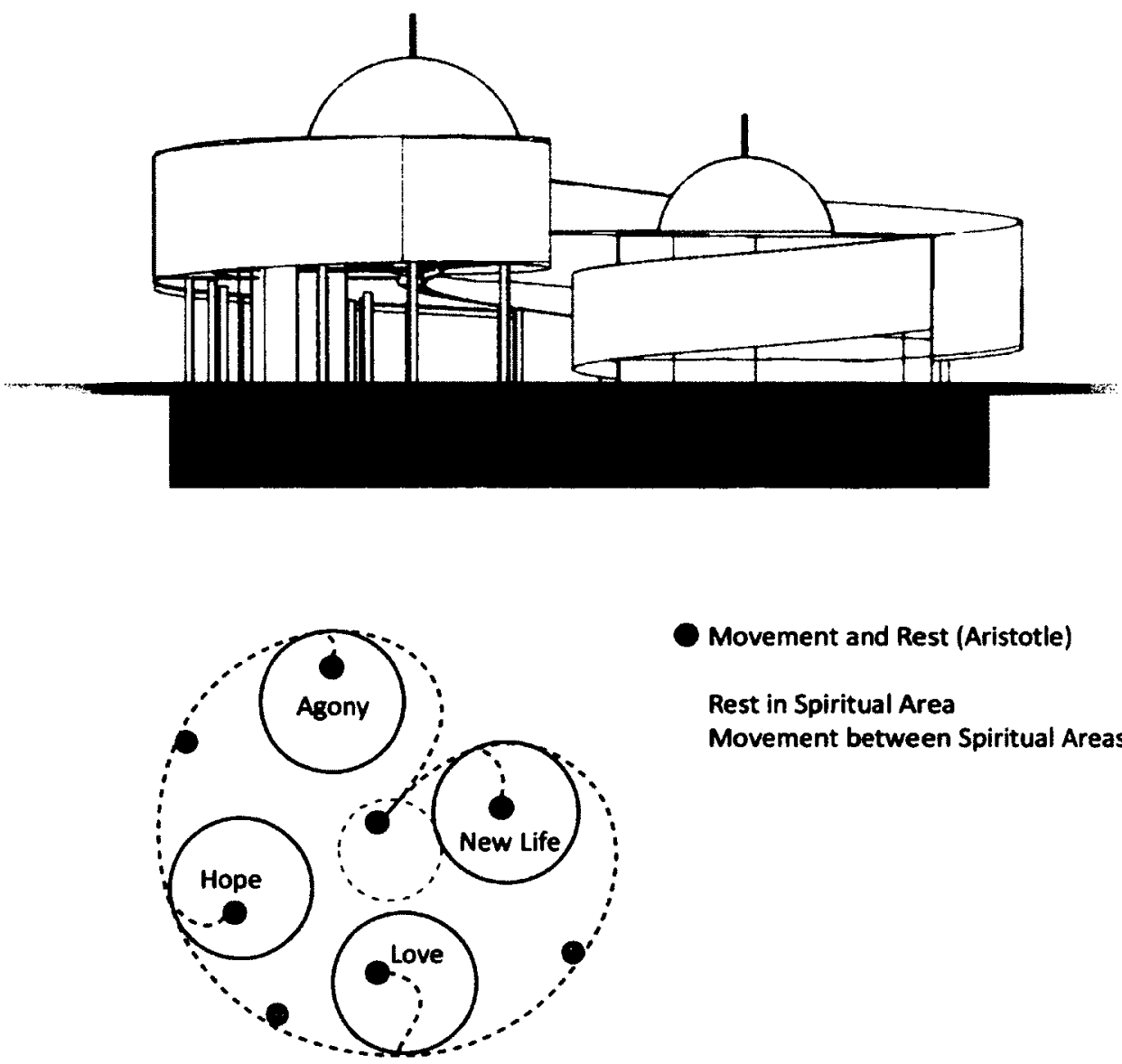

Movement and Rest (Aristotle)

Rest in Spiritual Area

Movement between Spiritual Areas

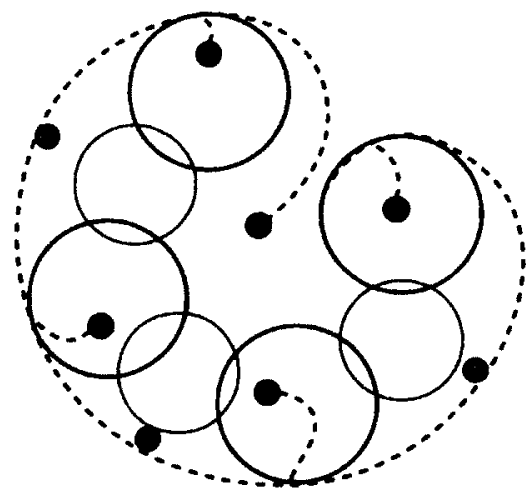

Introduction of

Secular Functions (Flexible)

-Exhibition Space

-Conference Space

-Sunday School

Figure 4.16. Graphic Elevation and Circulation Diagram. 


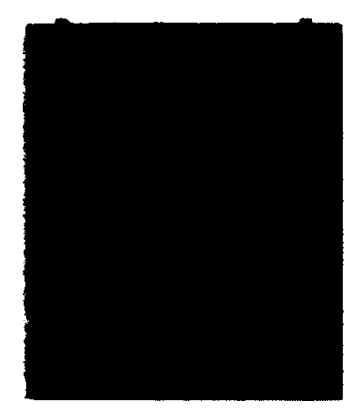

Figure 4.17 A. Forty Days after Pascha, the Ascen-

sion of Christ.

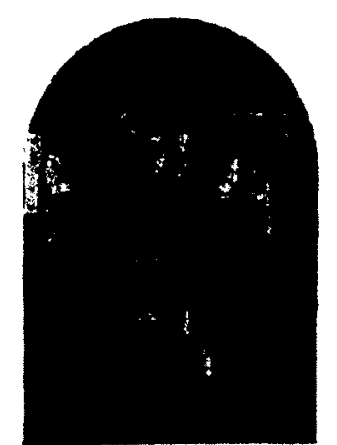

Figure 4.17 B. September 14, the Elevation of the Holy Cross.

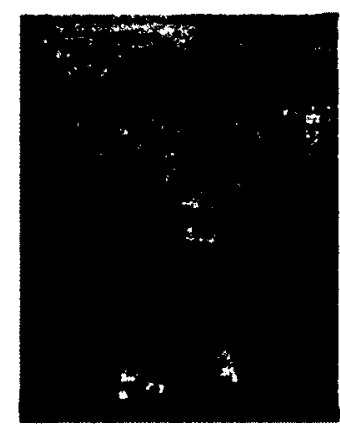

Figure 4.17C. The

Sunday before Poscho

Palm Sunday. 


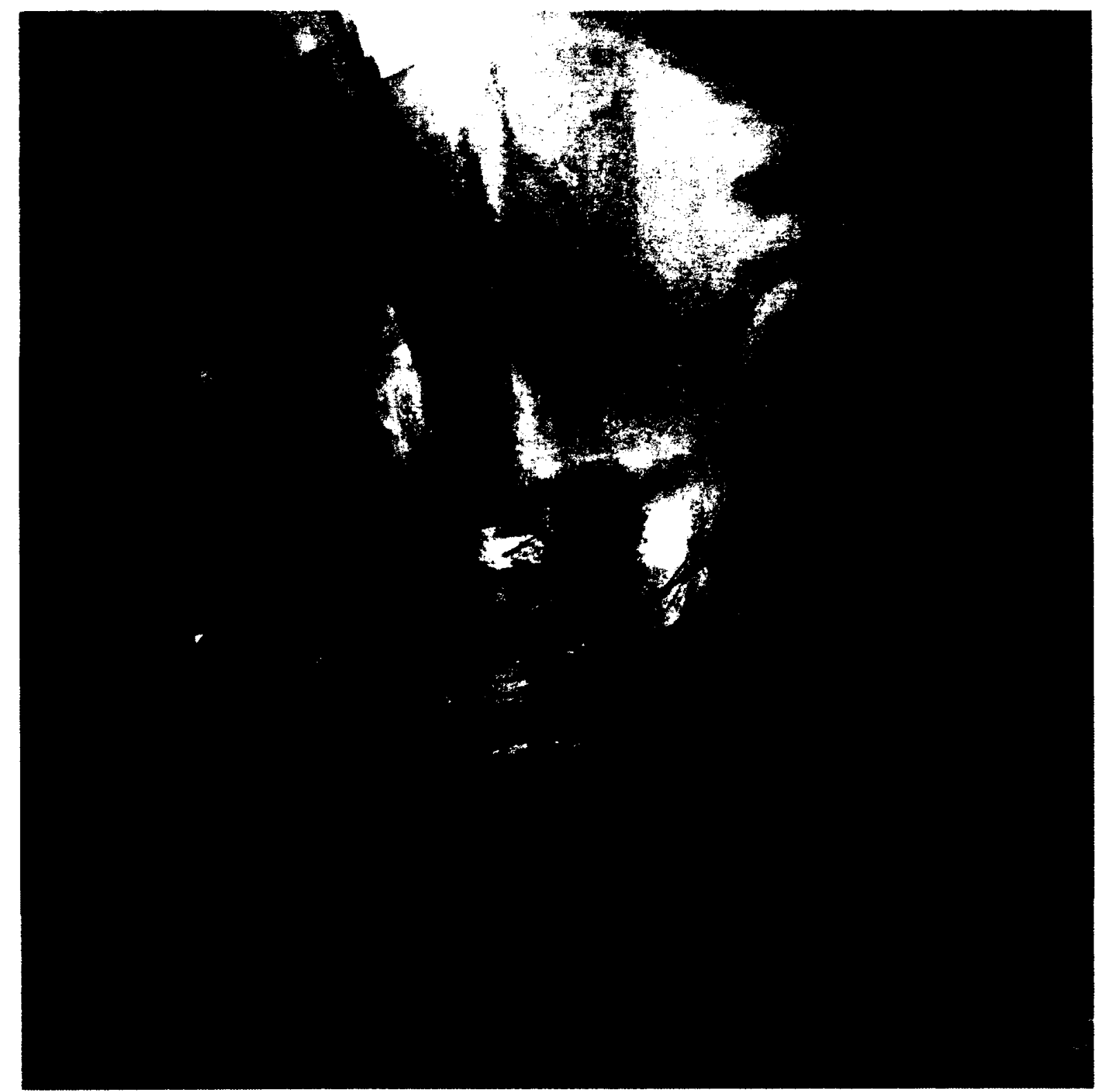

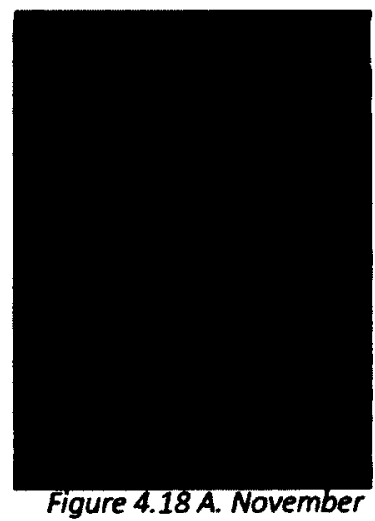

21, the Presentation of the Theotokos.

Figure 4.18. 'Hope'/Baptism.

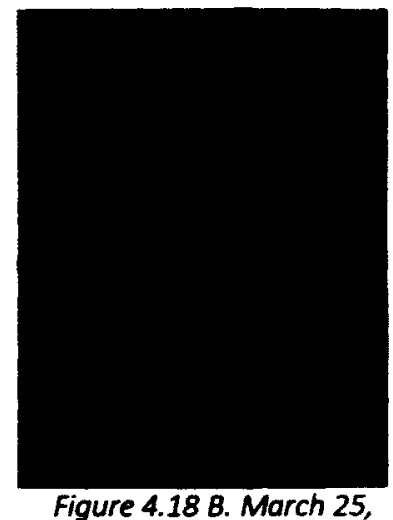

the Annunciation.

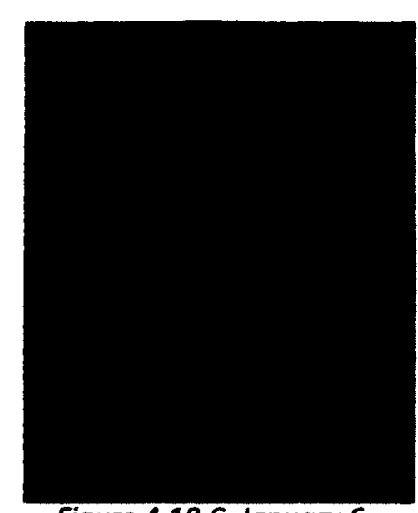

Figure 4.18 C. January 6 , Theophany, the Baptism of Christ. 


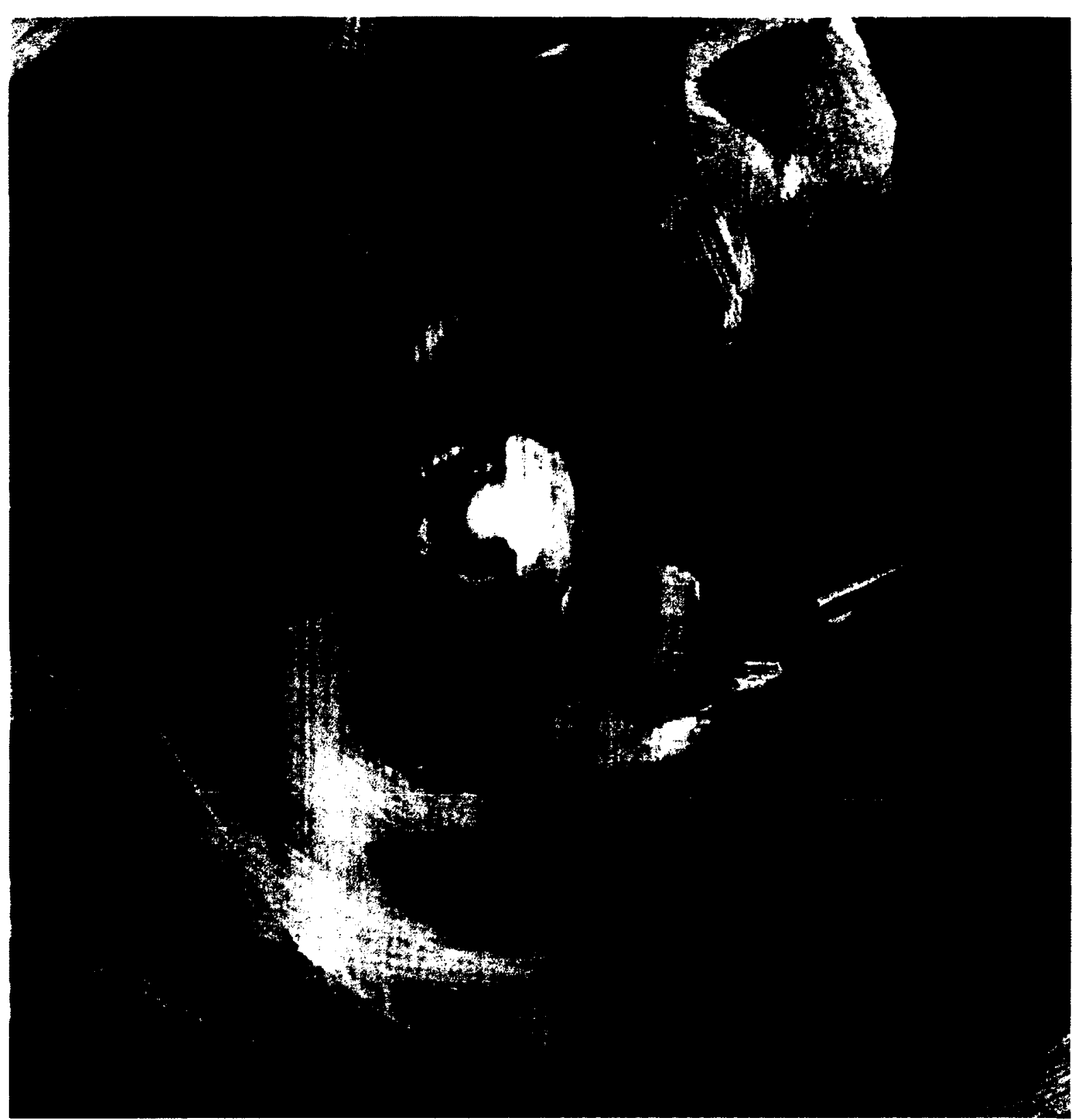

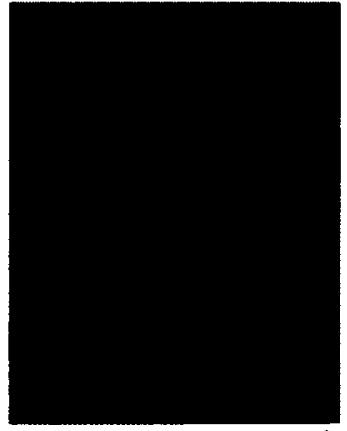

Figure 4.19 A. September 8 , the Nativity of Theotokos.

Figure 4.19. 'Love'/Confession.

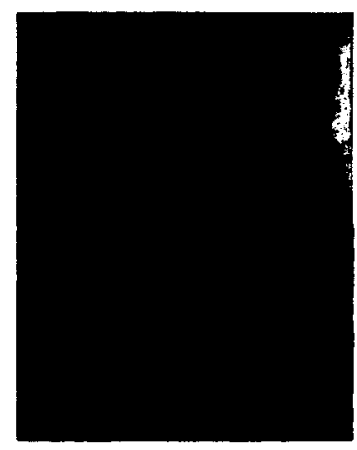

Figure 4.19 B. December 25, the Nativity of Christ (Christmas)

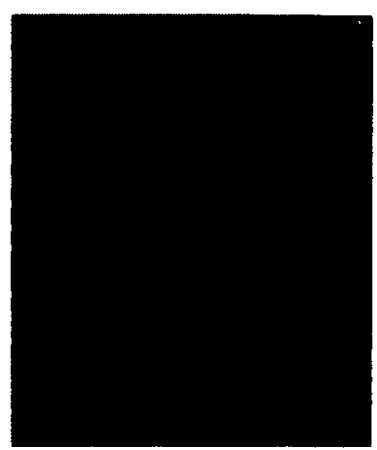

Figure 4.19 C. Fifty Days after Pascha, Pentecost. 


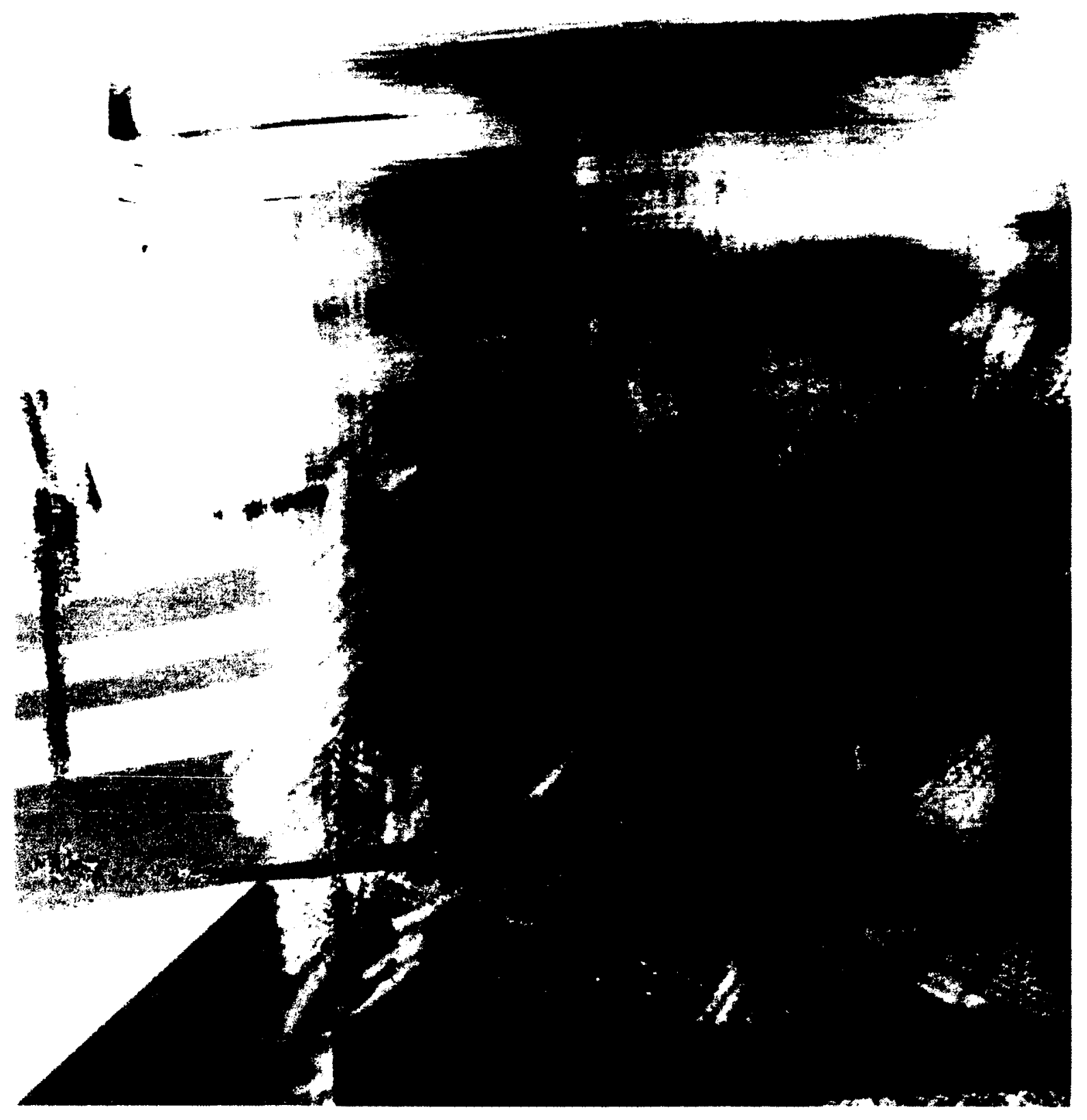

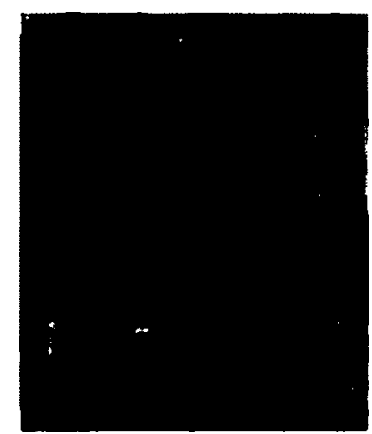

Figure 4.20 A. February 2, the Presentotion of Christ.

Figure 4.20. 'Hope'/Liturgy.

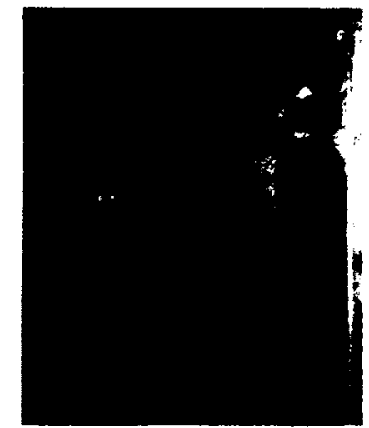

Figure 4.20 B. August 15, the Dormition of the Theotokos.

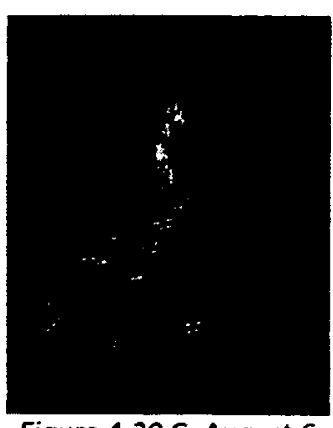

Figure 4.20 C. August 6, the Transfiguration. 


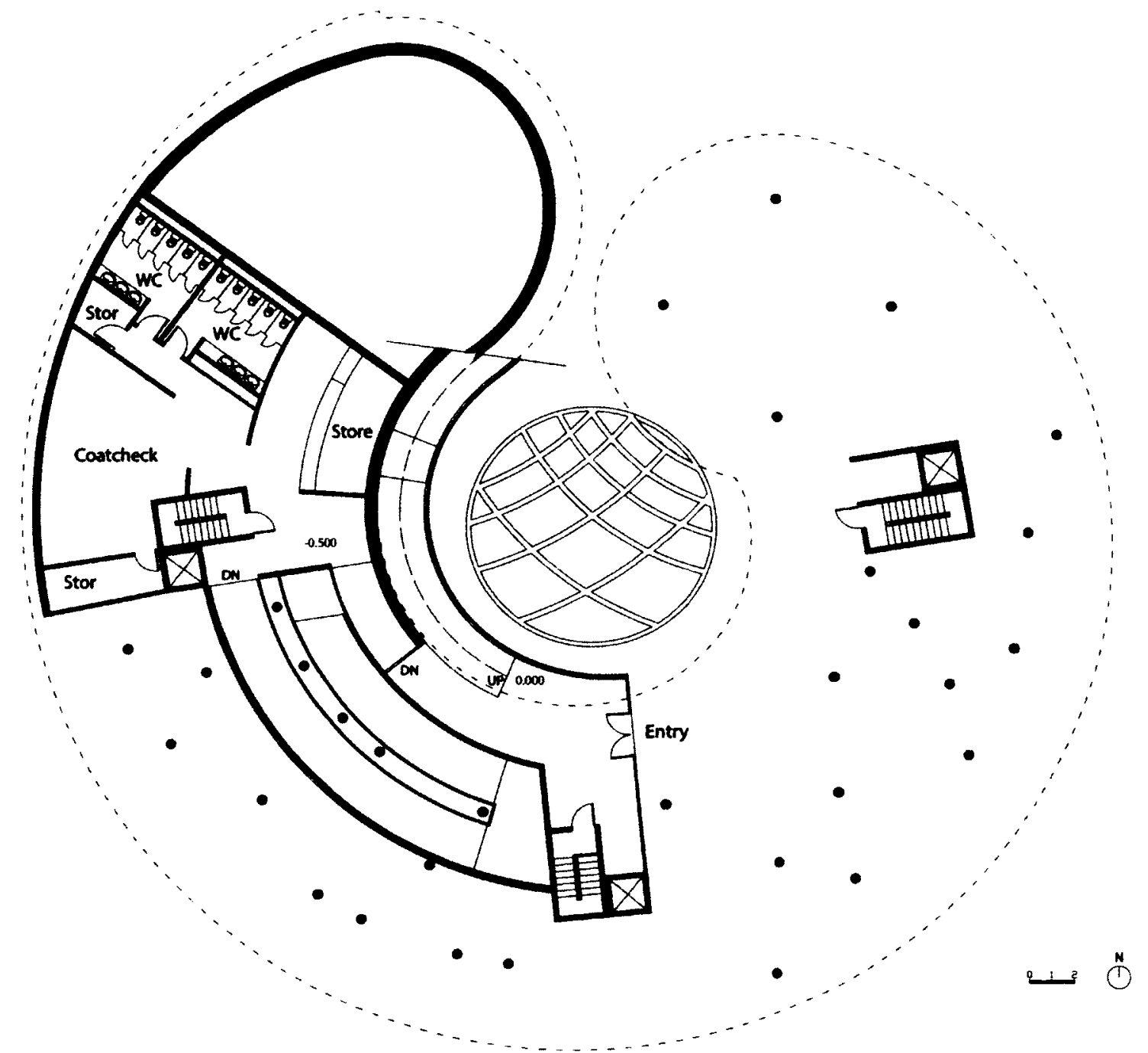

Figure 4.21. Plan. Entry Level. 


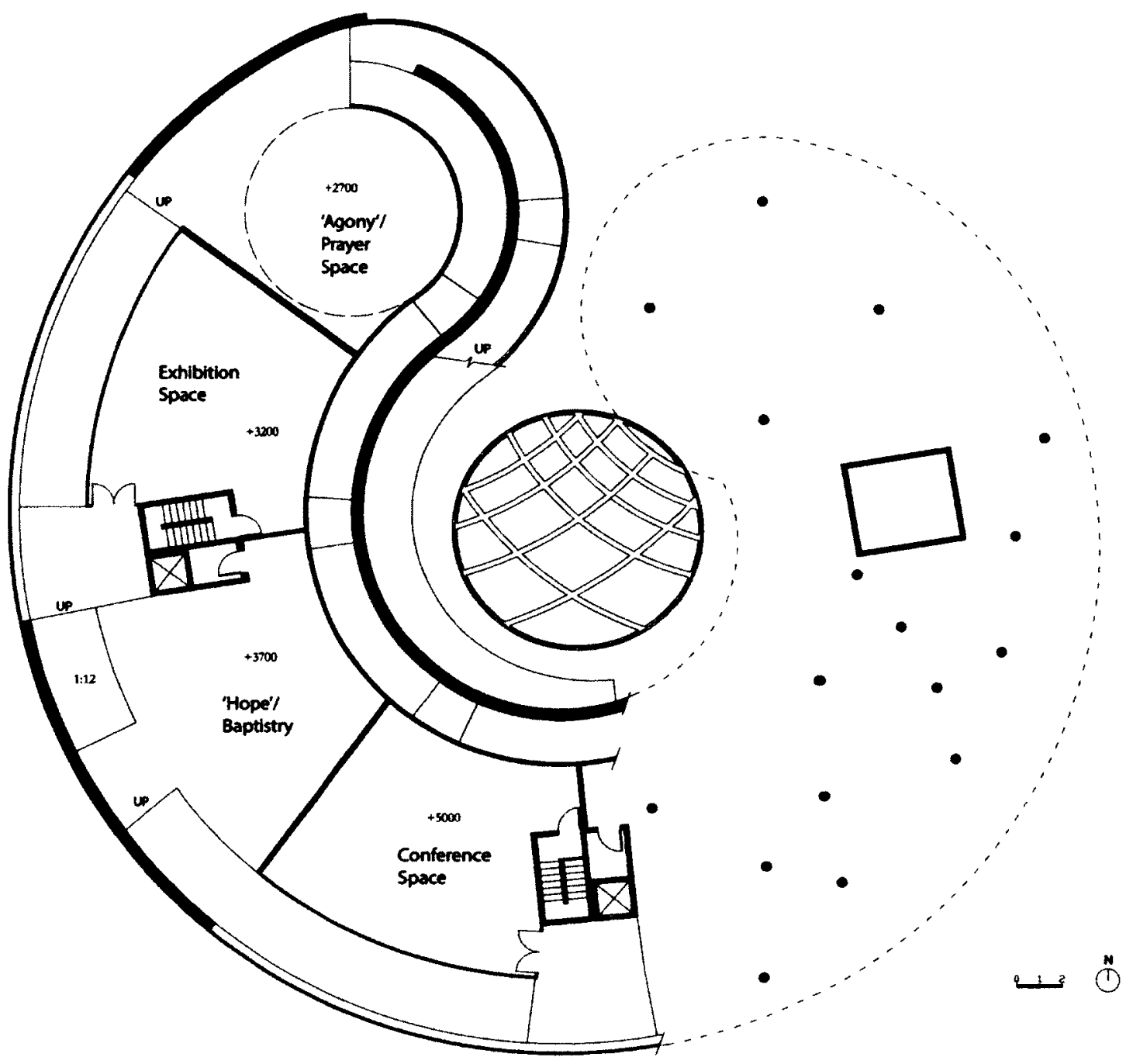

Figure 4.22. Plan. 'Agony'/Prayer Space and 'Hope'/Baptistry. 


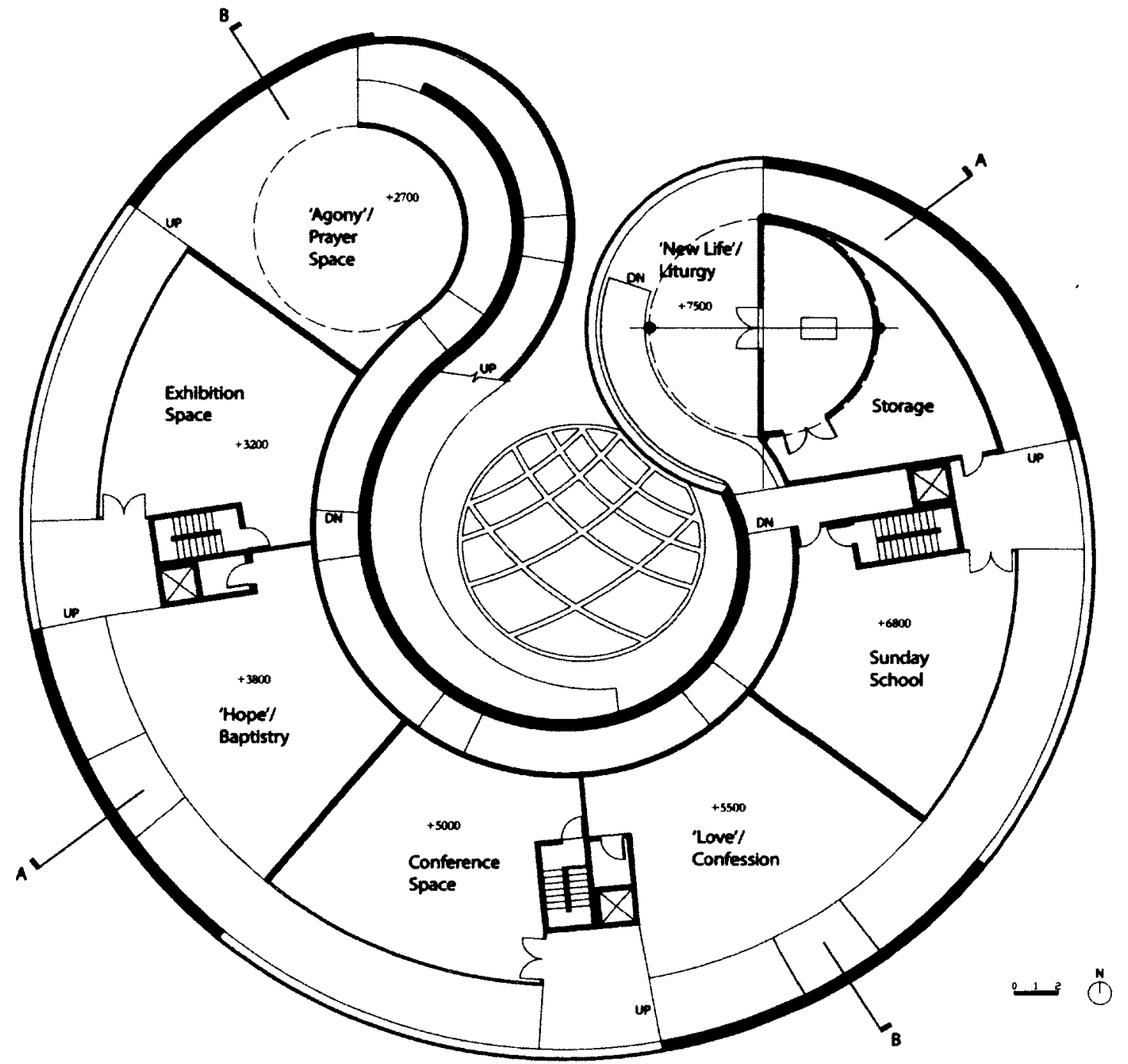

Figure 4.23. Plan- 'Love'/Confession and 'New Life'/Liturgy. 


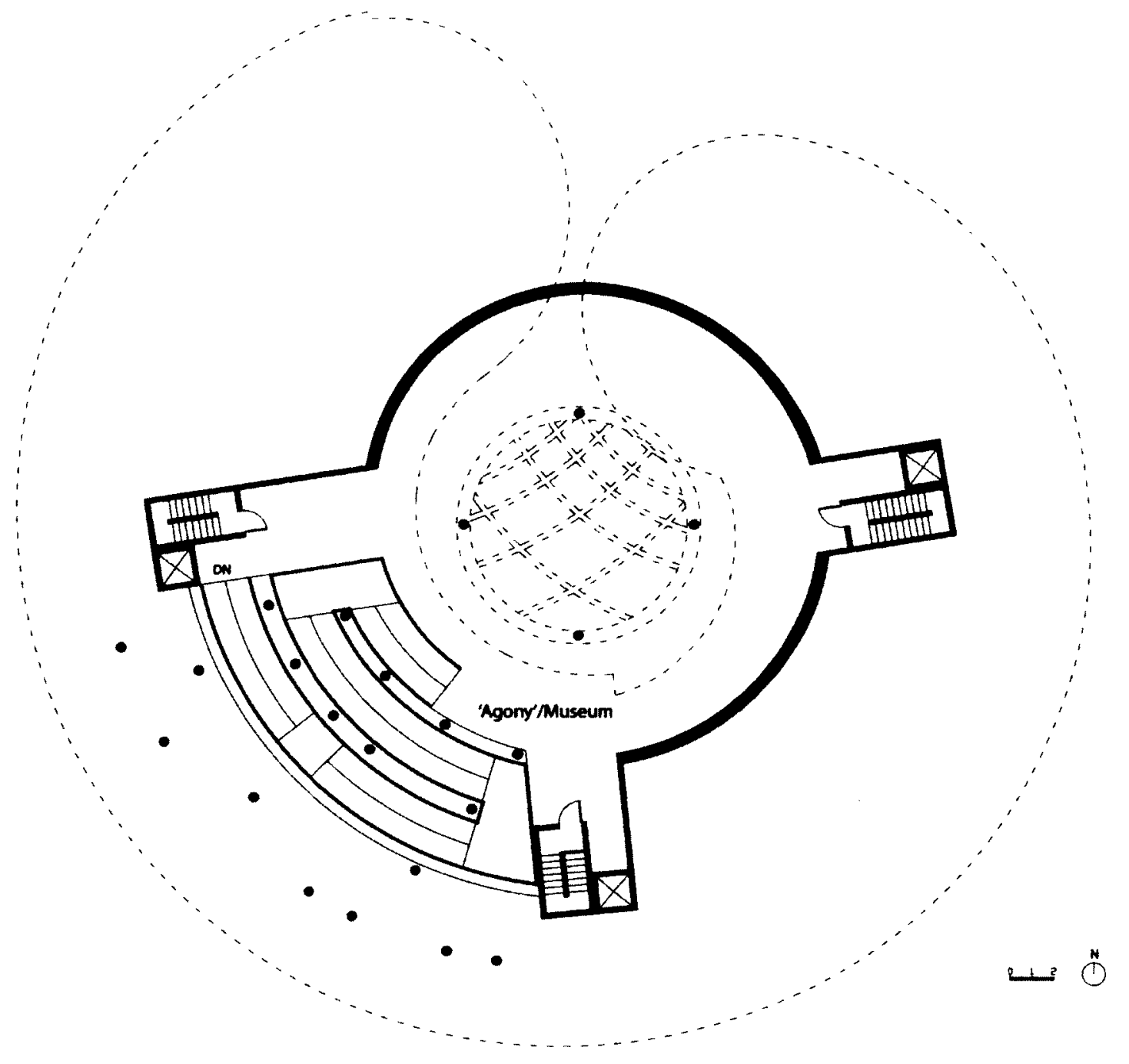

Figure 4.24. Plan- 'Agony'/Museum. 


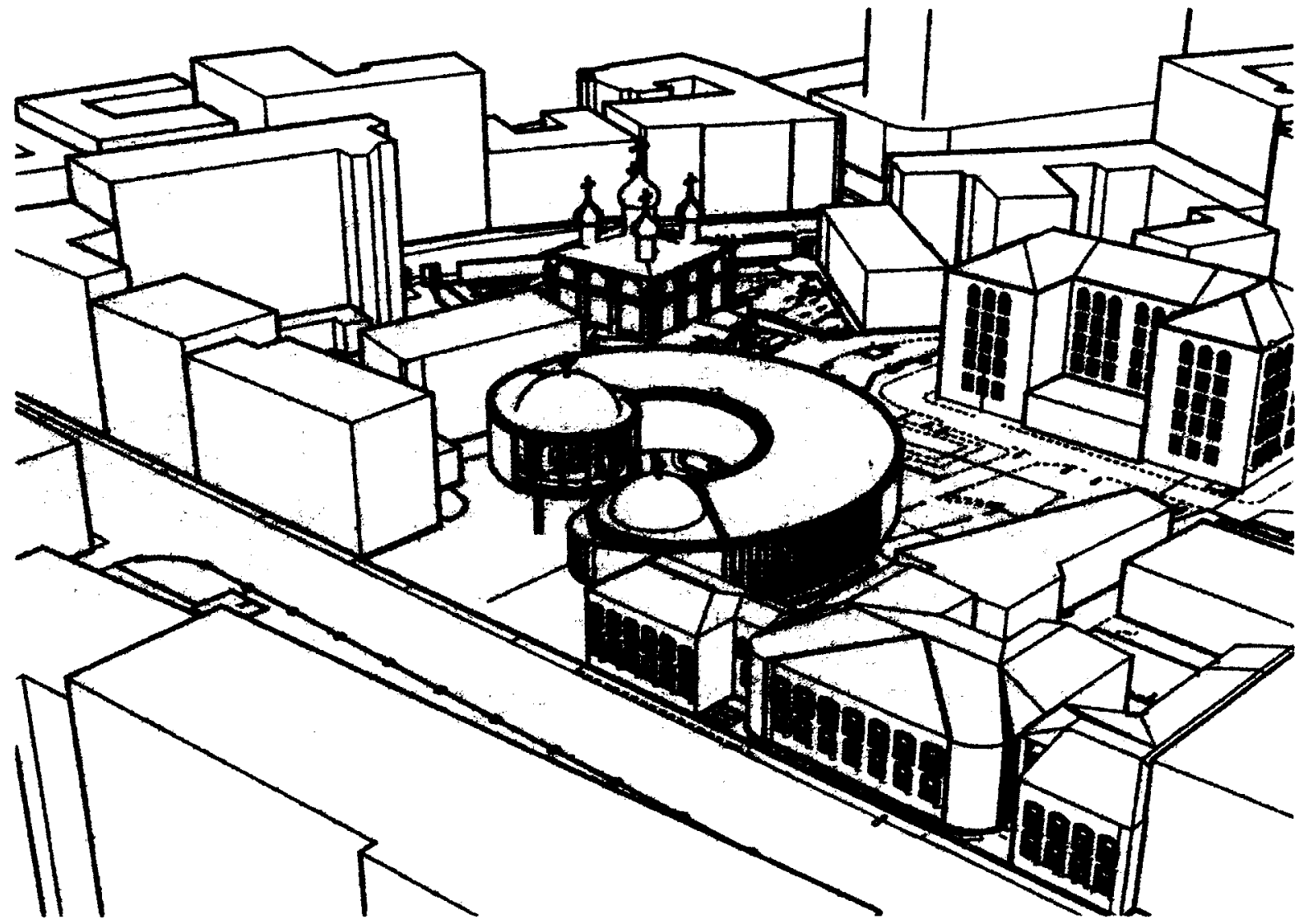

Figure 4.24. Overall church view. 


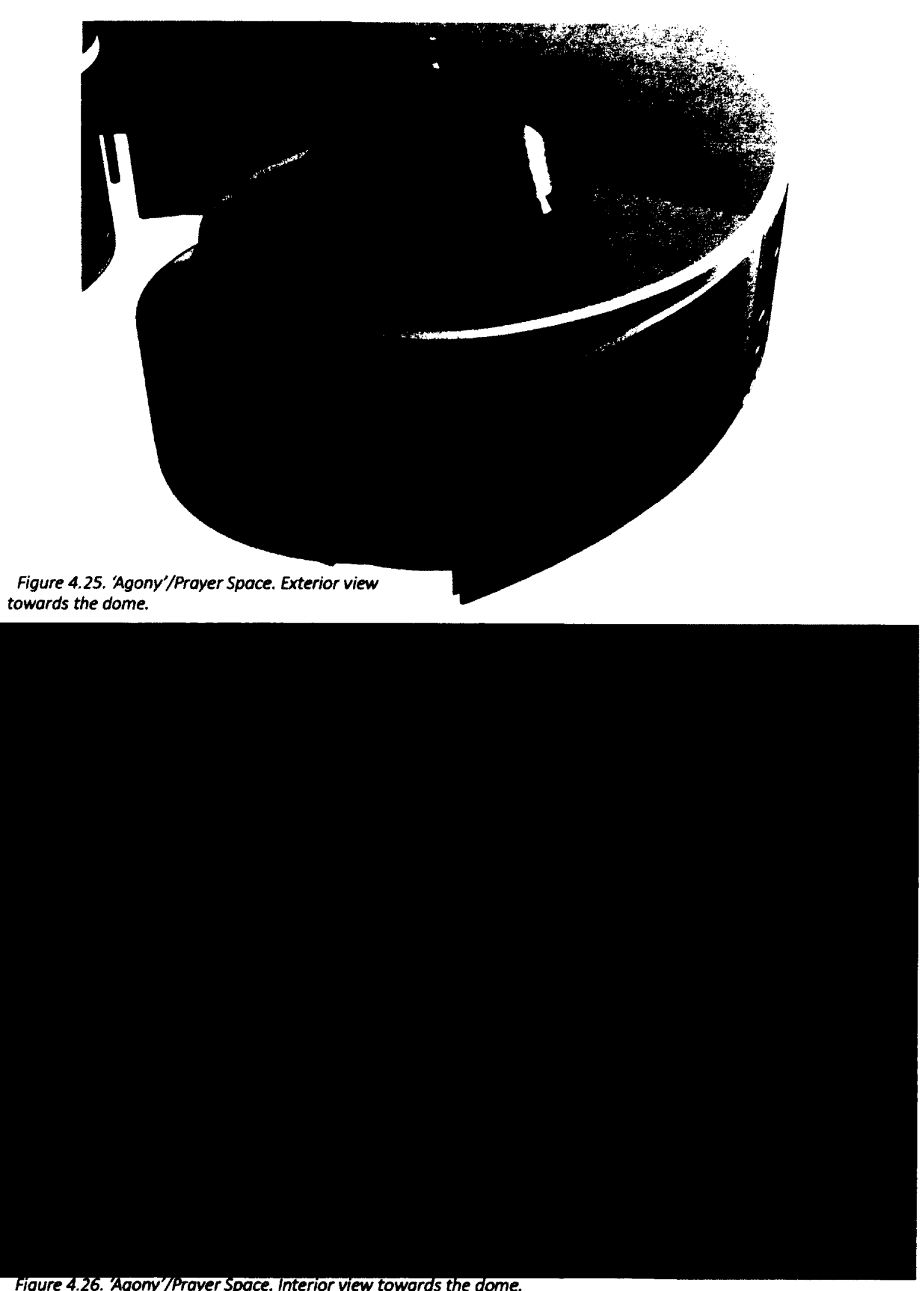

Figure 4.26. Agony 7Prayer Space. Interior view towards the dome. 


$$
\text { 무잉 }
$$




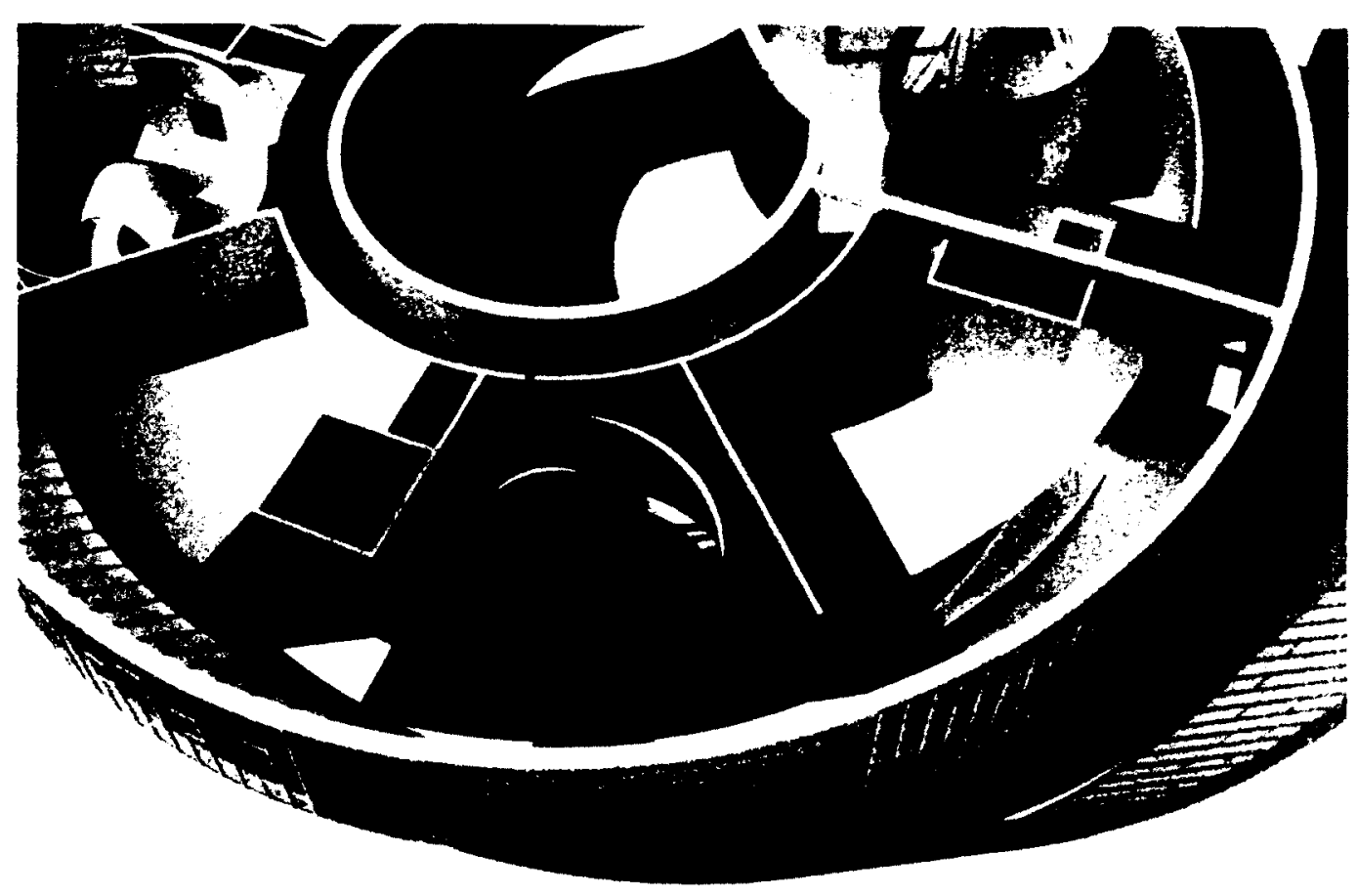

Figure 4.29. 'Love'/Confession Space. Interior.

Figure 4.30. 'Love'/Confession Space. Interior. 


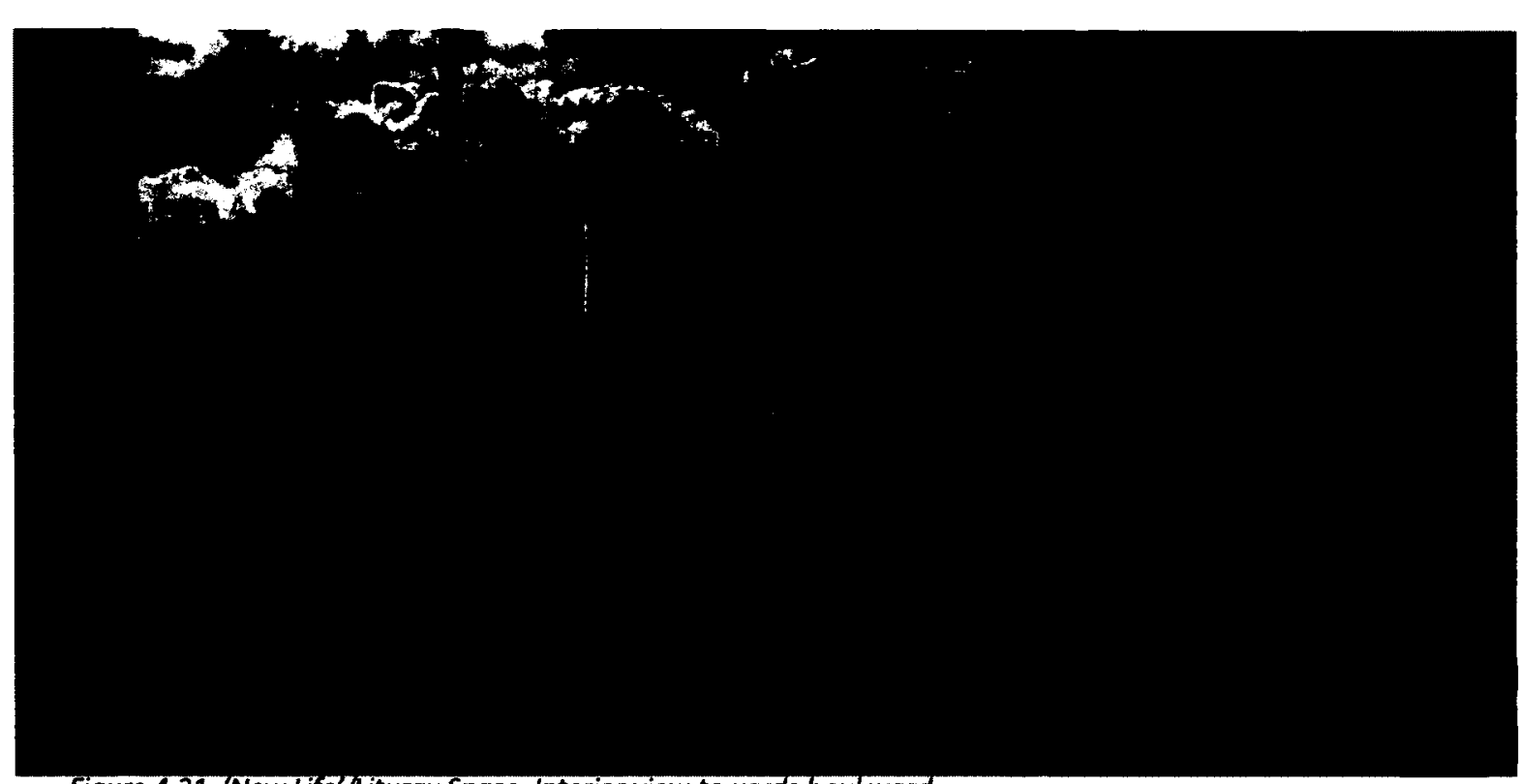

Figure 4.31. New Life'hiturgy Space. Interior view towards boulevard.

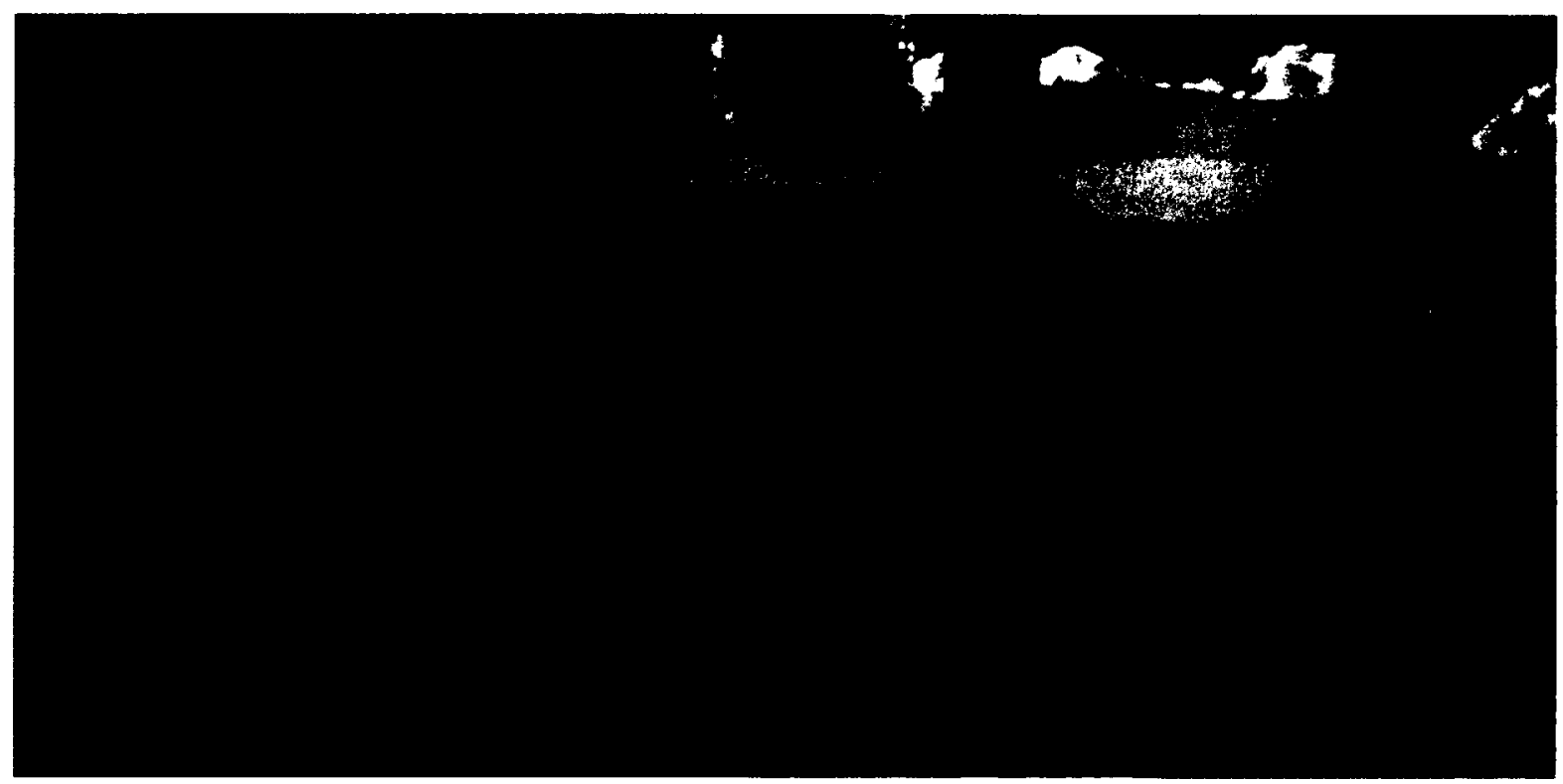

Figure 4.32. 'New Life'/Liturgy Space. Interior view of the gradual building elevation. 
Figure 4.33. Night view from the boulevard.

Figure 4.34. Night view from the street. 


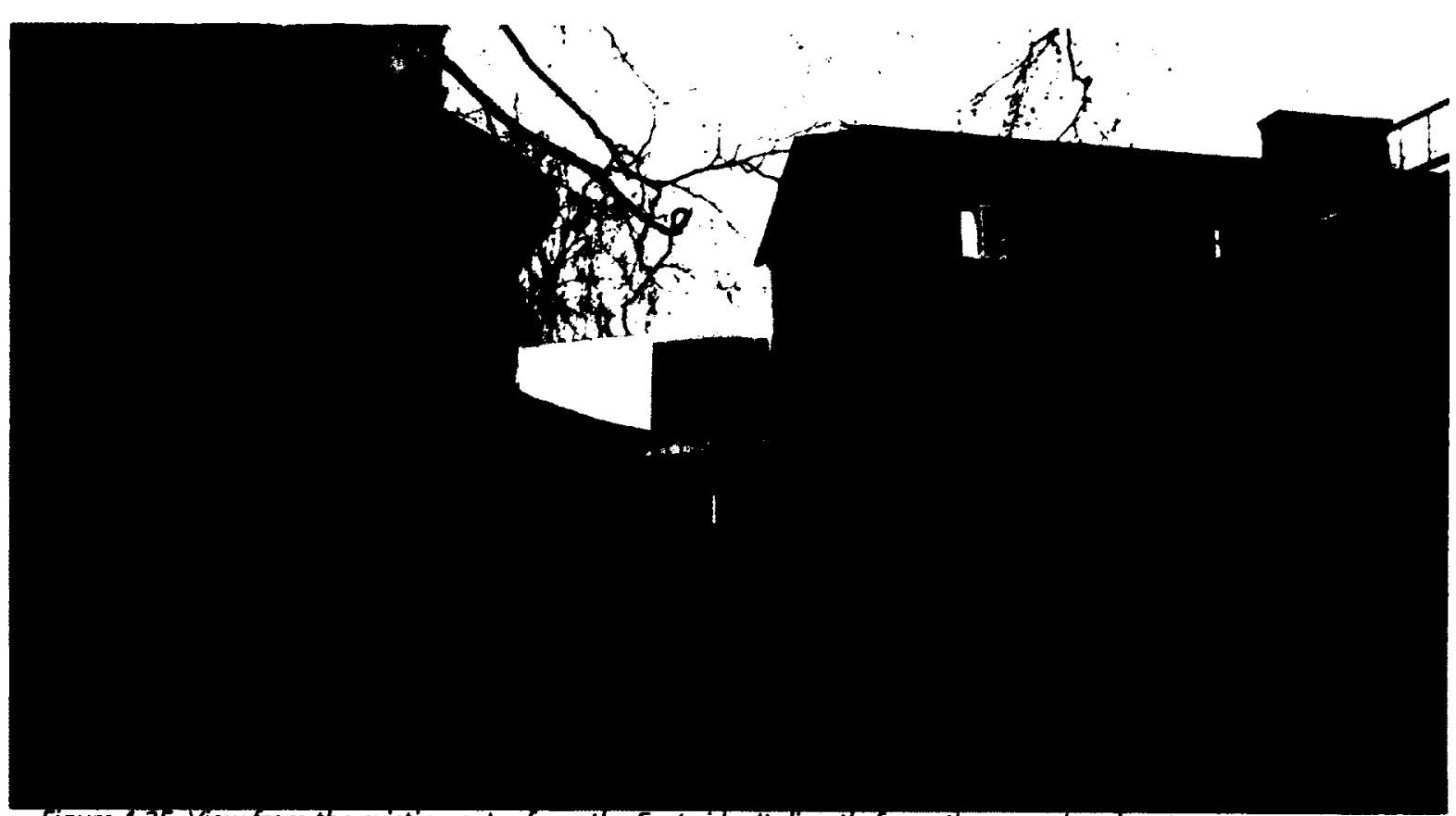

Figure 4.35. View from the existing entry from the East side. It directly faces the new church entry.

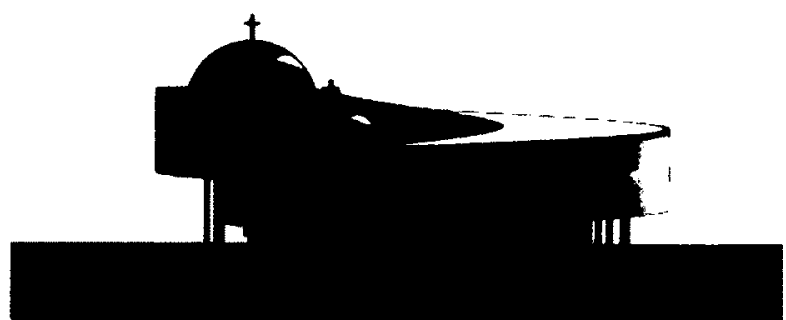

Figure 4.36. West Elevation. (NTS).

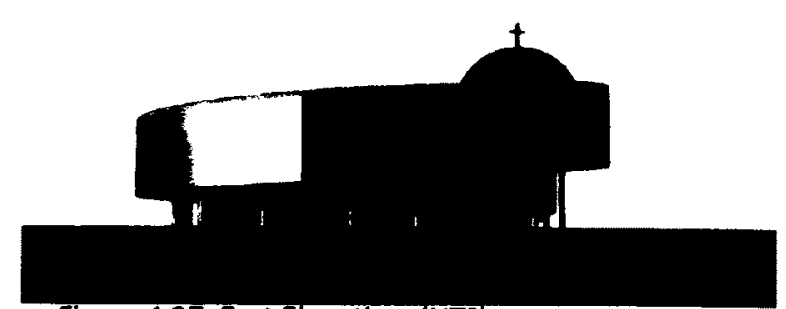

Figure 4.37. East Elevation. (NTS). 


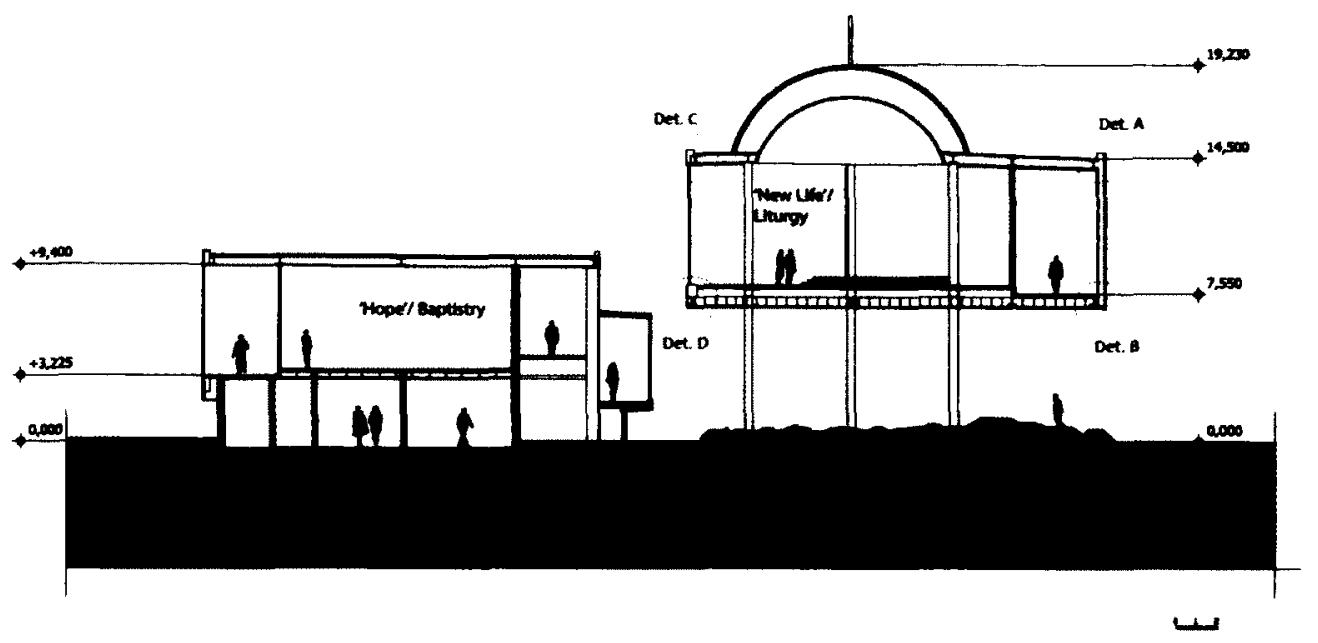

Figure 4.38. Section A-A.

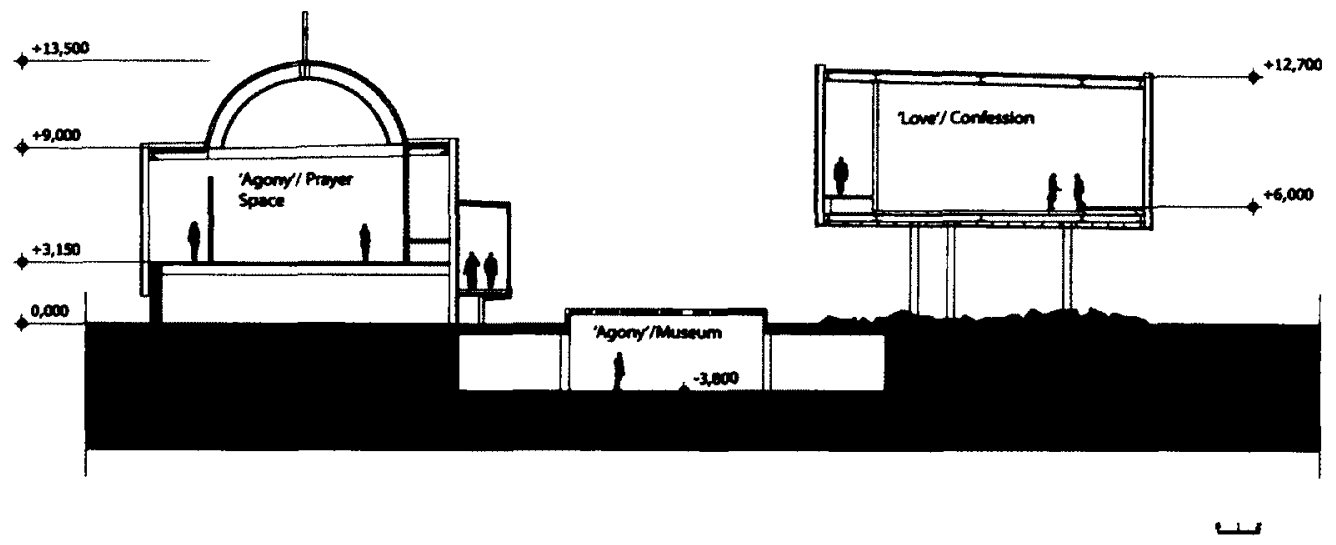

Figure 4.39. Section B-B. 

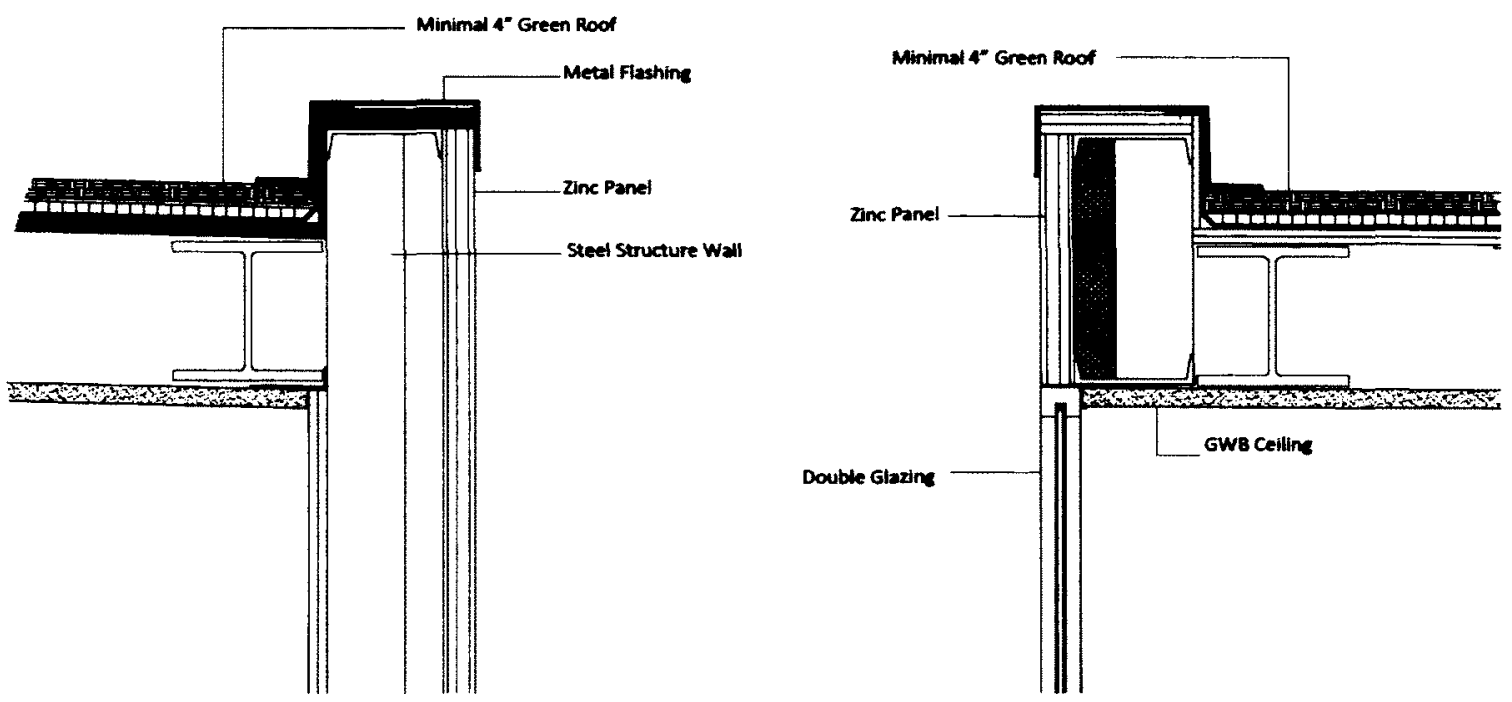

Detail A. NTS

Detail C. NTS
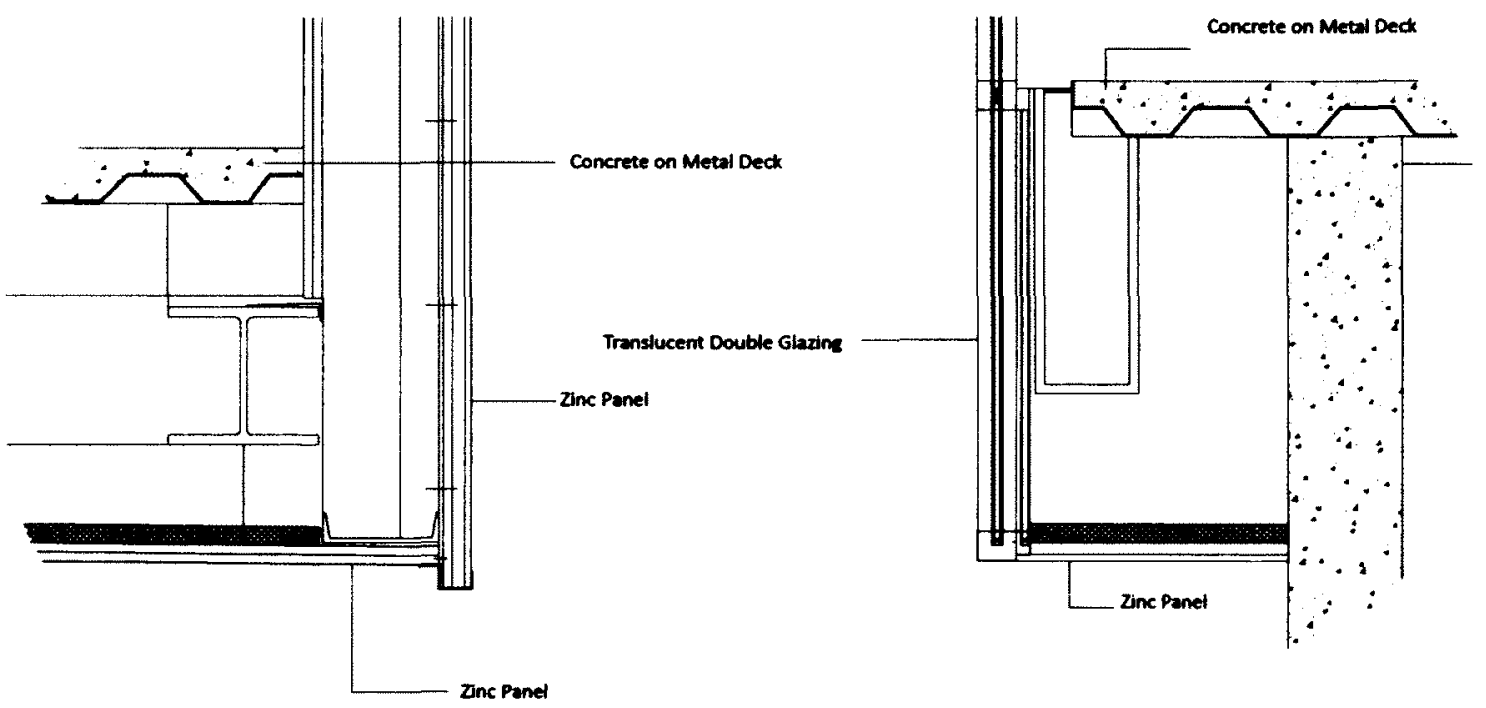

Detail B. NTS

Detail D. NTS

Figure 4.40. Detail Sections. (NTS). 
Through research, this thesis became an exploration into a subject of a long-time interest: how to express unlimited strength and richness of the human soul in an architectural manifestation. The vastness of the soul is related to the visual, virtual and narrative in their essentially unlimited amount of potential. The quest for their re-definition in this thesis was important for the inevitable context of exponential technological growth, as these aspects inevitably affect the architectural design process.

The project site and context are quite complex in terms of culture, history and theology. The application of Metaphysical Lens to this complexity has helped to coherently organize its various elements, based on the visual, virtual and narrative. My original attempt to follow a traditional Russian Orthodox church model was misleading in relation to the intent of reconciling history and religion to contemporary condition. The Metaphysical Lens has actually helped to architecturally express the concept of reconciliation during the design process.

In relation to the virtual aspect, the Metaphysical Lens has transformed the traditional spatial organization of the church into a processional model, without distorting the original unity of meaning. The Earth-Sky relationship was left intact, while the spatial organization of the building was strongly specific to the context. The study of virtual in relation to the project has shown its strong symbolic side. Based on the readings research, The Metaphysical Lens has helped to bring the virtual from its commonly accepted dependence on digital technology to the human 'Being'. 
With regards to the visual, the Metaphysical Lens allowed to constructively express its complexity specifically for each designed space. Its physiological aspects containing light, color and texture were directed by the virtual and the narrative. The Metaphysical Lens enabled to transform the standard spatial 'feel' of the church into unique spaces. From this research it became evident that the major aspect of the visual relates to how a person would experience the building, both inside and outside. It directed the choice of materials, colors, and light within the building.

The 'Metaphysical Lens' is intended to be used in the future as a conceptual framework for the design process. It is meant to accommodate a great variety of architectural programs, whether spiritual or secular. The 'Lens' is individualIy defined, and as such it is not a closed conceptual system. A closed system would limit the conceptual framework creating too much control over the design process. It is important to outline processes and a personal position that could be used by any architect at their discretion. This way, each designer would have a personal 'Metaphysical Lens' for a creative process. In this way, the 'Metaphysical Lens' is a flexible framework for design.

I have learned that it provides an ability to constructively approach a complex project without limiting its specific religious context. On another hand, for example, the uniqueness of each narrative within the 'Lens' still requires a well-informed approach that is sensitive to an overall context. There is always an area for improvement within the 'Lens', as the definition of its components is vast. This research will be useful personally, as well as generally for architects willing to challenge their 'Being' in the process of an architectural manifestation. 
List of Figures:

Figure 01. Movement, Time, Space.

"'Star Trails at Loch Thom, Scotland' by David James | Redbubble." Accessed May 9, 2013. http://www.redbubble.com/people/ davidburrows/works/4559947-star-trails-at-loch-thom-scotland.

Figure 02. Image of the Vladimirsky Cathedral in Sretensky monastery. Photo by Michael Chupricove.

Figure 1.1. Duchamp descending a staircase. Study of body form in motion."Duchamp: An Eliot Elisofon Retrospective." Accessed May 9, 2013. http://www.hrc.utexas.edu/exhibitions/2000/elisofon/elisofon17.html.

Figure 1.2. Umberto Boccioni. "Unique Forms of Continuity in Space." 1913."Umberto Boccioni: Unique Forms of Continuity in Space (1990.38.3). Heilbrunn Timeline of Art History.The Metropolitan Museum of Art." Accessed May 9, 2013. http://www. metmuseum.org/toah/works-of-art/1990.38.3.

Figure 1.3. Antonio Sant'Elia. Sketch for an Electric Power Plant. 1914.“Antonio Sant'Elia - Electric Power Plant, 1914 - Fine Arts Reproduction, Individual Art Card." Kunst-fuer-alle.de. Accessed May 9, 2013. http://www.kunst-fuer-alle.de/english/fine-art/ artist/image/antonio-sant'elia/6387/1/107506/electric-powerplant,-1914/index.htm.

Figure 1.4. An example of reverse perspective in the icon portraying St. Mathew. Translated by author. "Icon and Image (from the Book by S.V. Alekseev 'The Visible Truth'). Art Studio 'Icon'." Accessed May 9, 2013. http://ikonadrevo.ru/publ/ikona_i_kartina_iz_knigi_s_v_alekseeva_quot_zrimaja_istina_quot/1-1-0-4.

Figure 1.5. Luciano Laurana. "The Ideal City". 11th Century. "Idealcit.jpg" Accessed May 9, 2013. http://www.anatomyofnorbiton.org/images/idealcit.jpg.

Figure 1.6. Patrick Hughes. "Vanishing Venice". Mid-20th Century. "Patrick Hughes. Hilton Fine Art Gallery." Accessed May 9, 2013. http://hiltonfineart.com/content/patrick-hughes.

Figure 1.7. A diagram showing the relationship between the icon 'screen' and the location of viewpoint."An Icon As an Image: Direct and Reverse Perspective." Accessed May 9, 2013. http:// www.pravmir.com/article_449.html. 
Figure 1.8. Diller Scofidio+Renfro. The "Blur Building"."Blur1.jpg" Accessed May 9, 2013. http://www.okeanosgroup.com/blog/wpcontent/uploads/2011/11/blur1.jpg.

Figure 1.8 A. Jean Nouvel - Louvre Museum, Abi Dhabi, United Arab Emirates. (Expected 2015). "Eikongraphia". Accessed May 9, 2013. http://www.eikongraphia.com/?p=1334

Figure 1.9. An interactive screen by Sawapan. Body movement creates a constantly changing interactive mesh."Mqdefault.jpg" Accessed May 9, 2013. http://i4.ytimg.com/vi/3vwnk7f5xQU/ mqdefault.jpg.

Figure 1.10. Herzog De Meuron Architects. Trinity Laban Conservatoire of Music \& Dance."Laban_centre_1020310_tc1.jpg" Accessed May 9, 2013. http://www.e-architect.co.uk/images/jpgs/ architects/laban_centre_1020310_tc1.jpg. "optimized-maxW950-NGUT-arch-0043.jpg" Accessed May 9, 2013. http://thecreativefinder.com/userfiles/members/nickguttridge1/18544/optimized-maxW950-NGUT-arch-0043.jpg.

Figure 1.11. Greg Lynn. "Embryological Housing". "greg_lynn_Embriological_Housing.jpg" Accessed May 9, 2013. http://oud.digischool.nl/ckv2/ckv3/kunstentechniek/lynn/greg_ lynn_Embriological_Housing.jpg.

Figure 1.12. CAVE virtual system.

"Frank_CAVE.jpg" Accessed May 9, 2013. http://ispr.info/ files/2011/12/Frank_CAVE.jpg.

Figure 1.13. Video game virtual space. "2438123681_a5172b6cc5_0.jpg” Accessed May 9, 2013. http://farm4.static.flickr.com/3049/2438123681_a5172b6cc5_o. jpg.

Figure 1.14. "Topostruct" by Sawapan.

"Sawapan : Topostruct." Accessed May 9, 2013. http://www.sawapan.eu/.

Figure 1.15. A vector ribbon diagram of a molecule. "Lenoir_FlowProcessFold.pdf" Accessed May 9, 2013. http://www.stanford.edu/dept/HPS/TimLenoir/Publications/ Lenoir_FlowProcessFold.pdf

Figure 1.16. A massing location guidance map at the Architectural 
Association School of Architecture in London.

"Creative Mapping." Accessed May 9, 2013.

http://mww.canadianarchitect.com/news/creative-map-

ping/1000972161/.

Figure 1.17. An example of mapping from data.

"Urban Mapping.Moscow." Behance. Accessed May 9, 2013.

http://www.behance.net/gallery/URBAN-MAPPING-MOS-

cow/3408789.

Figure 2.01. Entering a story that follows a physical path from the universe into the space and then explores the effects of different seasons. Authors: Simon Weiss and Arley Kim.

Engeli, Maia. Digital Stories: The Poetics of Communication.

Springer,2000.56.

Figure 2.02. LEED v 2.2 Mind Map from Pomodoro Design. "BIMBuilder.com / Revit 3D: June 2009." Accessed May 9, 2013. http://bimboom.blogspot.ca/2009_06_01_archive.html.

Figure 4.1. View from inside of the Sretensky Monastery towards the current entry. A stone Cross has been installed near the site in commemoration of New Martyrs. Photo by Michael Chupricove.

Figure 4.3. Map of Moscow, Russia. (NTS) The city is ring-based, the inner (smaller ring), called the 'Garden Ring' is made up of green, public boulevards, which are popular public spaces. The site is located next to Rozhdestvensky (Resurrection) Boulevard.

Map modified by author. Original reference: Translation by author. "Materials for Project Development." Accessed May 9, 2013. http://dwg.ru/.

Figure 4.4. Map of Moscow, Russia. (NTS) The location of the Sretensky Monastery in relation to the KGB building and the Kremlin. Map modified by author. Original reference: Translation by author. "Materials for Project Development." Accessed May 9, 2013. http://dwg.ru/.

Figure 4.5. Image of destruction of the Sretensky monastery in the late 1920 's.

Translation by Author. "Photography - Sretensky Monastery - The Beginning of Demolition. Version 2." Accessed April 2, 2013. http://unw.oldmos.ru/photo/view/46195

Figure 4.6. Image of destruction of the Sretensky monastery in 
the late 1920's.

Translation by Author. "Photography - Sretensky Monastery - The demolition of the church of St. Mary of Egypt." Accessed April 2, 2013. http://www.oldmos.ru/photo/view/45913

Figure 4.7. A view of the Vladimirsky Cathedral. Photo by Michael Churpricove.

Figure 4.8. A Schematic Model of an Orthodox Church with Symbolic Meaning of its Elements. Original Source: Translated by Author. "MDS 31-9.2003 Orthodox Churches. Part 2. Orthodox Churches and Complexes. Manual For Project Development and Construction for SP 31-103-99 - Free Download.Accessed May 9, 2013. http://www.gosthelp.ru/text/MDS3192003Pravoslavnyexra.html.

Figure 4.9. Reassessment of symbolic spatial organization of the church architecture with 'Metaphysical Lens'. Original Source: Translated by Author. "MDS 31-9.2003 Orthodox Churches. Part 2. Orthodox Churches and Complexes. Manual For Project Development and Construction for SP 31-103-99 - Free Download.Accessed May 9, 2013. http://www.gosthelp.ru/text/MDS3192003Pravoslavnyexra.html.

Figure 4.10. An example of iconostasis. Photo by Nadezhda Sivakova.

Figure 4.11. Images of nearby streets. Photo by Michael Chupricove.

Figure 4.12. Street-view of the site. Original souce: "Sretensky Monastery - Google Maps." Accessed May 9, 2013. https://maps.google.ca/maps?q=sretensky+monastery\&oe =utf-8\&aq=t\&rls=org. mozilla:en-US:official\&client=firefox$a \& u m=1 \& i e=U T F-8 \& h l=e n \& 5 a=N \& t a b=w I$.

Figure 4.13. Site Plan. (NTS). By author.

Figure 4.14. Site Plan with the church. (NTS). By author.

Figure 4.15. 'Memory' Concept Section. By author.

Figure 4.16. Graphic Elevation and Circulation Diagram. By author.

Figure 4.17. 'Agony' / Prayer. By author. 
Figure 4.17 A. Forty Days after Pascha, the Ascension of Christ.

"Icons of the Great Feasts.A Reader's Guide to Orthodox Icons." Accessed May 9, 2013. http://iconreader.wordpress.com/iconsof-the-great-feasts/.

Figure 4.17 B. September 14, the Elevation of the Holy Cross. "Icon_holycross.jpg" Accessed May 9, 2013. http://www.holycross-stsconstantinehelen.org/Images/Icons/icon_holycross.jpg.

Figure $4.17 \mathrm{C}$. The Sunday before Pascha, Palm Sunday.

"Icons of the Great Feasts.A Reader's Guide to Orthodox Icons." Accessed May 9, 2013. http://iconreader.wordpress.com/iconsof-the-great-feasts/.

Figure 4.18. 'Hope'/Baptism. By author.

Figure 4.18 A. November 21, the Presentation of the Theotokos. "Icons of the Great Feasts.A Reader's Guide to Orthodox Icons." Accessed May 9, 2013. http://iconreader.wordpress.com/iconsof-the-great-feasts/.

Figure 4.18 B. March 25, the Annunciation.

"Icons of the Great Feasts.A Reader's Guide to Orthodox Icons." Accessed May 9, 2013. http://iconreader.wordpress.com/iconsof-the-great-feasts/.

Figure 4.18 C. January 6, Theophany, the Baptism of Christ. "Icons of the Great Feasts.A Reader's Guide to Orthodox Icons." Accessed May 9, 2013. http://iconreader.wordpress.com/iconsof-the-great-feasts/.

Figure 4.19. 'Love'/Confession. By author.

Figure 4.19 A. September 8, the Nativity of Theotokos. "Icons of the Great Feasts.A Reader's Guide to Orthodox Icons." Accessed May 9, 2013. http://iconreader.wordpress.com/iconsof-the-great-feasts/.

Figure 4.19 B. December 25, the Nativity of Christ (Christmas) "Icons of the Great Feasts.A Reader's Guide to Orthodox Icons." Accessed May 9, 2013. http://iconreader.wordpress.com/iconsof-the-great-feasts/.

Figure 4.19 C. Fifty Days after Pascha, Pentecost.

"Icons of the Great Feasts.A Reader's Guide to Orthodox Icons." 
Accessed May 9, 2013. http://iconreader.wordpress.com/iconsof-the-great-feasts/.

Figure 4.20. 'Hope'/Liturgy. By author.

Figure 4.20 A. February 2, the Presentation of Christ.

"Icons of the Great Feasts.A Reader's Guide to Orthodox Icons." Accessed May 9, 2013. http://iconreader.wordpress.com/iconsof-the-great-feasts/.

Figure 4.20 B. August 15, the Dormition of the Theotokos. "Icons of the Great Feasts.A Reader's Guide to Orthodox Icons." Accessed May 9, 2013. http://iconreader.wordpress.com/iconsof-the-great-feasts/.

Figure 4.20 C. August 6, the Transfiguration.

"Icons of the Great Feasts.A Reader's Guide to Orthodox Icons." Accessed May 9, 2013. http://iconreader.wordpress.com/iconsof-the-great-feasts/.

Figure 4.21. Plan. Entry Level. By author.

Figure 4.22. Plan. 'Agony' /Prayer Space and 'Hope'/Baptistry. By author.

Figure 4.23. Plan- 'Love'/Confession and 'New Life'/Liturgy. By author.

Figure 4.24. Plan- 'Agony'/Museum. By author.

Figure 4.24. Overall church view. By author.

Figure 4.25. 'Agony'/Prayer Space. Exterior view towards the dome. By author.

Figure 4.26. 'Agony'/Prayer Space. Interior view towards the dome. By author.

Figure 4.27. 'Hope'/Baptism Space. Interior. By author.

Figure 4.28. 'Hope'/Baptism Space. Interior. By author.

Figure 4.29. 'Love'/Confession Space. Interior. By author.

Figure 4.30. 'Love'/Confession Space. Interior. By author. 
Figure 4.31. 'New Life'/Liturgy Space. Interior view towards boulevard. By author.

Figure 4.32. 'New Life'/Liturgy Space. Interior view of the gradual building elevation. By author.

Figure 4.33. Night view from the boulevard. By author.

Figure 4.34. Night view from the street. By author.

Figure 4.35. View from the existing entry from the East side. It directly faces the new church entry. By author.

Figure 4.36. West Elevation. (NTS). By author.

Figure 4.37. East Elevation. (NTS). By author.

Figure 4.38. Section A-A. By author.

Figure 4.39. Section B-B. By author.

Figure 4.40. Detail Sections. (NTS). By author.Icon images - Sources 


\section{Bibliography}

Antonova, Clemena. "On the Problem of 'Reverse Perspective': Definitions East and West." Leonardo 43, no. 5 (2010): 464-469.

Crysler, Greig C., Stephen Cairns, and Hilde Heynen. The SAGE Handbook of Architectural Theory. SAGE, 2012

Curcic, Slobodan, and Evangelia Hadjitryphonos. Architecture as Icon: Perception and Representation of Architecture in Byzantine Art. Princeton University Art Museum, 2010.

Damisch, Hubert. The Origin of Perspective. Translated by John Goodman. New edition. The MIT Press, 1995.

Engeli, Maia. Digital Stories: The Poetics of Communication. Springer, 2000

Florensky, Pavel. History and Philosophy of Art. http://predanie. ru/lib/book/read/75786/\#TOC_id2551973.Author's translation.

Frascari, Marco. Eleven Exercises in the Art of Architectural Drawing: Slow Food for the Architect's Imagination. 1st ed. Routledge, 2011.

Gaffney, Peter, ed. The Force of the Virtual: Deleuze, Science, and Philosophy. Univ Of Minnesota Press, 2010.

Author's translation. N.K. Gavryushina. 'Philosophy of Russian Religious Art'. Moscow, Progress, 1993.

Imperiale, Alicia. New Flatness: Surface Tension in Digital Architecture. Springer, 2000.

Kak, Subnash. Active Agents, Intelligence and Quantum Computing.Information Sciences, vol. 128, pp. 1-17, 2000

Kwinter, Sanford. Architectures of Time: Toward a Theory of the Event in Modernist Culture. MIT Press, 2002

Lauwereyns, Jan. Brain and the Gaze: On the Active Boundaries of Vision. MIT Press, 2012.

Lomholt, Jane, Paul Emmons, and John Shannon Hendrix. The 
Maligrave, Harry Francis, and David Goodman. An Introduction to Architectural Theory: 1968 to the Present. John Wiley \& Sons, 2011.

Manser, Martin H., and Jessica Feinstein. Heinemann English Dictionary. Heinemann, 2001.

Moffett, Marian, Michael W. Fazio, and Lawrence Wodehouse. A World History of Architecture. Laurence King Publishing, 2003. Maligrave, Harry Francis, and David Goodman. An Introduction to Architectural Theory: 1968 to the Present. John Wiley \& Sons, 2011.

Ponte, Alessandra, and Antoine Picon. Architecture and the Sciences: Exchanging Metaphors. Princeton Architectural Press, 2003.

Various authors. Understanding Media, Today: McLuhan in the Era of Convergence Culture. Editorial UOC, 2011.

\section{Web:}

"Peirce Dictionary: Virtual." Accessed May 9, 2013. http://www. helsinki.fi/science/commens/terms/virtual.html.

Aristotle. "Metaphysics." Text, 2002. Accessed May 9, 2013. http://ebooks.adelaide.edu.au/a/aristotle/metaphysics/.

"Aristotle's Metaphysics." Accessed May 9, 2013. http://www. angelfire.com/md2/timewarp/firstphilosophy.html.

Sachs, Joe. "Aristotle: Motion and Its Place in Nature." Internet Encyclopedia of Philosophy (2005). Accessed May 9, 2013. http:// www.iep.utm.edu/aris-mot/.

"Aristotle: The Body and Soul." Accessed May 9, 2013. http:// www.scandalon.co.uk/philosophy/aristotle_body_soul.htm.

"Nihilism - Definition and More from the Free Merriam-Webster Dictionary." Accessed May 9, 2013. http://www.merriam-webster. com/dictionary/nihilism

Translation by author. 'Florensky P.A. The Reverse Perspective.' Accessed December 07, 2013. http://philologos.narod.ru/florensky/fl_persp.htm. 
Translation by author. "Why Are New Martyrs Forgotten? Orthodox Journal 'The Garden of Learning'." Accessed May 9, 2013. http://www.nsad.ru/articles/pochemu-zabyvayut-novomuchenikov.

"Sretensky Stavropeghial Monastery." Accessed May 9, 2013. http://www.pravoslavie.ru/english/sretmon.htm.

Translation by author."News-National Archive of Administrative Ministry of Sverdlovskaya Oblast. Ekaterinburg." Accessed May 9, 2013. http://gaaoso.ru/page/?id=556\&n=316.

Translation by author. "How Many Repressed People in Russia Suffered For Christ? Orthodoxy and the World."Accessed May 9, 2013. http://www.pravmir.ru/skolko-repressirovannyx-v-rossiipostradali-za-xrista/.

"DailyTech - Ternary Computing Might Make Its Big Debut with Quantum Computing." Accessed May 9, 2013. http://www.dailytech.com/Ternary+Computing+Might+Make+its+Big+Debut+with +Quantum+Computing/article11387.htm.

"Ternary.pdf" Accessed April 5, 2013. http://www.inf.fu-berlin. de/lehre/WSO1/ALPI/ternary.pdf

"Re: Binary Switching Logic Circuits Versus Rotary Switching 1 to n Position Switching Logic Circuits." February 25, 2013. http:// newsgroups.derkeiler.com/Archive/Comp/comp.arch/2011-08/ msg00148.html.

"Sebastiano Serlio (Italian Architect) - Britannica Online Encyclopedia." Accessed April 6, 2013. http://www.britannica.com/ EBchecked/topic/535700/Sebastiano-Serlio.

"Peirce's Theory of Signs." Accessed February 10, 2013. http:// www.clas.ufl.edu/users/jzeman/peirces_theory_of_signs.htm.

"Definition of Tectonic in Oxford Dictionaries (British \& World English)." Accessed May 9, 2013. http://oxforddictionaries.com/ definition/english/tectonic.

"Online Etymology Dictionary." Accessed April 7, 2013. http:// www.etymonline.com/index.php?term=tectonic.

"The Definition of Symbol." Dictionary.com. Accessed April 7, 
2013. http://dictionary.reference.com/browse/symbol.

"30 CAVE." Accessed April 01, 2013. http://www.casala.ie/3dcave.html.

Ortiz de Gortari, Angelica B. and Griffiths, Mark D. "An Introduction to Game Transfer Phenomena in Video Game Playing." ACcessed April 7, 2013. http://www.academia.edu/1175748/

Translation by author."A Brick In the Building Of Eternity: Orthodoxy and the World." Accessed April 02, 2013. http://www. pravmir.ru/nash-kirpich-v-zdanii-vechnosti/.

Translation by author. "Philosophy Of An Image Of A New Temple: Orthodoxy and the World." Accessed April 02, 2013. http://www. pravmir.ru/filosofiya-obraza-novogo-xrama/.

Version of notes translated by author. Sergey Pimenov 'Plato, Aristotle' as part of 'Antique Phiosophy' course. Accessed April 4, 2013. http://predanie.ru/audio/online/istoria-filisofii/

Version of notes translated by author. Sergey Pimenov 'Charles Sanders Peirce. William James.' Accessed February 15, 2013. http://predanie.ru/audio/online/istoria-filisofii/

Version of notes translated by author. Sergey Pimenov 'History from the Renaissance to the XX Century'. Accessed February 15, 2013. http://predanie.ru/audio/online/istoria-filisofii/ 


\section{Notes}


Notes 